Prepared in cooperation with the Papio-Missouri River and Lower Platte North Natural Resources Districts and the Nebraska Department of Natural Resources

\title{
Groundwater Movement and Interaction with Surface Water near the Confluence of the Platte and Elkhorn Rivers, Nebraska, 2016-18

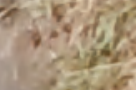

Scientific Investigations Report 2019-5048

U.S. Department of the Interior: U.S. Geological Survey

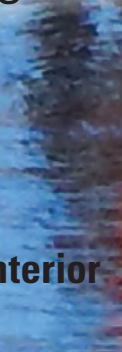

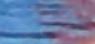

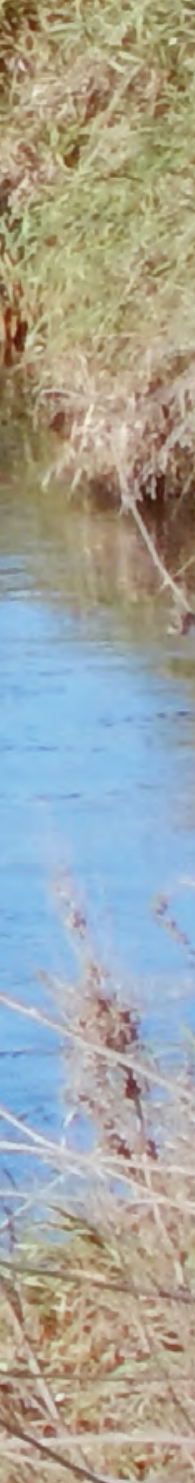


Cover. U.S. Geological Survey personnel measuring the discharge of Rawhide Creek (Old Channel) downstream of Fremont, Nebraska. Photograph by Kellan Strauch, U.S. Geological Survey. 


\section{Ground water Movement and Interaction with Surface Water near the Confluence of the Platte and Elkhorn Rivers, Nebraska, 2016-18}

By Christopher M. Hobza, Mason J. Johnson, Paul W. Woodward, Kellan R. Strauch, and Aaron R. Schepers

Prepared in cooperation with the Papio-Missouri River and Lower Platte North

Natural Resources Districts and the Nebraska Department of Natural Resources

Scientific Investigations Report 2019-5048 


\title{
U.S. Department of the Interior DAVID BERNHARDT, Secretary
}

\author{
U.S. Geological Survey \\ James F. Reilly II, Director
}

U.S. Geological Survey, Reston, Virginia: 2019

For more information on the USGS - the Federal source for science about the Earth, its natural and living resources, natural hazards, and the environment-visit https://www.usgs.gov or call 1-888-ASK-USGS.

For an overview of USGS information products, including maps, imagery, and publications, visit https://store.usgs.gov.

Any use of trade, firm, or product names is for descriptive purposes only and does not imply endorsement by the U.S. Government.

Although this information product, for the most part, is in the public domain, it also may contain copyrighted materials as noted in the text. Permission to reproduce copyrighted items must be secured from the copyright owner.

Suggested citation:

Hobza, C.M., Johnson, M.J., Woodward, P.W., Strauch, K.R., and Schepers, A.R., 2019, Groundwater movement and interaction with surface water near the confluence of the Platte and Elkhorn Rivers, Nebraska, 2016-18: U.S. Geological Survey Scientific Investigations Report 2019-5048, 38 p., https://doi.org/10.3133/sir20195048.

ISSN 2328-0328 (online) 


\section{Contents}

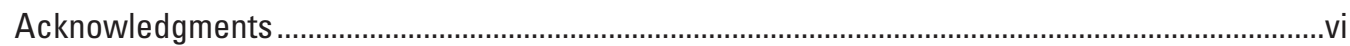

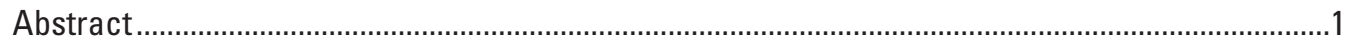

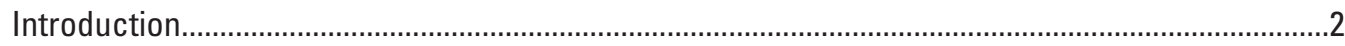

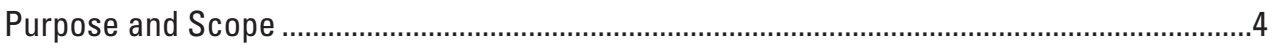

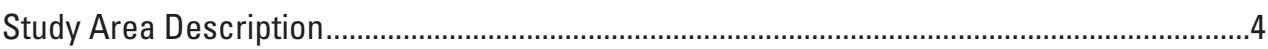

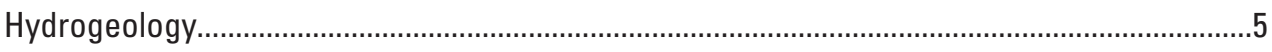

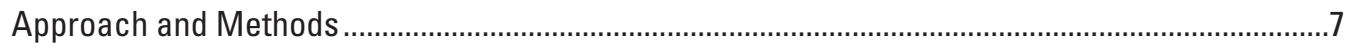

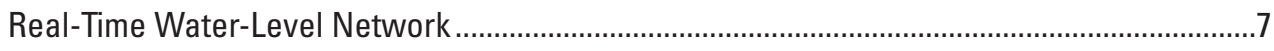

Synoptic Water-Level and Streamflow Survey.....................................................................

Aerial Thermal Infrared Imagery Methods.......................................................................... 10

Aerial Thermal Infrared Imagery Collection...........................................................10

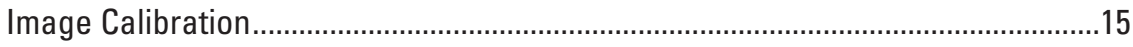

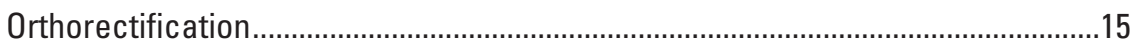

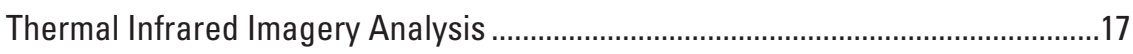

Temperature-Based Streambed Flux Estimates ..................................................................17

Location Selection and Data Collection......................................................................18

Streambed Flux Calculations and Analysis ..................................................................21

Groundwater Movement and Interaction with Surface Water near the Confluence of the

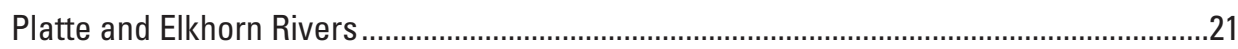

Streamflow and Local Climatic Conditions, 2016-18 ……...................................................22

Groundwater Movement Characteristics During Low Groundwater Demand Periods ..........23

Groundwater Movement Characteristics During High Groundwater Demand Periods .........25

Spatial and Seasonal Trends in Groundwater Movement Between the Platte and

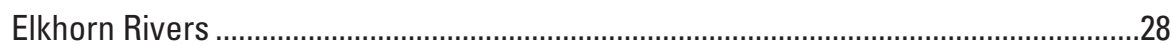

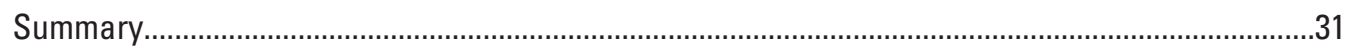

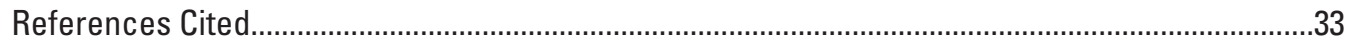




\section{Figures}

1. Map showing selected stream reaches, streamflow-gaging stations, recorder wells, and cross-section trace upstream from the confluence of the Platte and Elkhorn Rivers, Nebraska...

2. Cross-section of study area showing water-levels measured in recorder wells and streamflow-gaging stations from November 2016

3. Maps showing results from the low groundwater demand synoptic water-level and streamflow survey, November 2016

4. Maps showing results from the high groundwater demand synoptic water-level and streamflow survey, August 2017

5. Map of reach where aerial thermal infrared imagery was collected, self-logging temperature locations, and surface temperature of the Elkhorn River determined with aerial TIR, December 15, 2017.

6. Graphs showing measured daily discharge and median daily discharge

7. Hydrograph showing water-level elevation from recorder wells and streamflow-gaging stations, and hydraulic gradient 2016-18

8. Downstream temperature profile of the Elkhorn River from 0.5 mile upstream from the Elkhorn River at Waterloo, Nebraska, streamflow-gaging station to 1 mile downstream from the 0 Street Bridge.

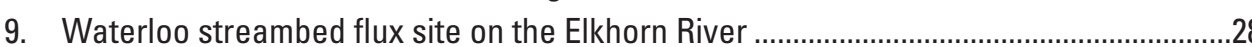

10. Elkhorn Crossing streambed flux site on the Elkhorn River.............................................30

\section{Tables}

1. Site number, geographic location, and selected well construction data for observation wells drilled near streamflow-gaging stations and recorder wells

2. Measured streamflow and measurement locations collected during low and high groundwater demand synoptic water-level and streamflow surveys

3. Location, configuration, and deployment period of vertical temperature arrays............19

4. Selected hydraulic and thermal parameters used in VFLUX2 calculations ...................21

5. Discharge and temperature data used in equation 2 to estimate groundwater discharge to the Elkhorn River. 


\section{Conversion Factors}

U.S. customary units to International System of Units

\begin{tabular}{|c|c|c|}
\hline Multiply & By & To obtain \\
\hline \multicolumn{3}{|c|}{ Length } \\
\hline inch (in.) & 2.54 & centimeter $(\mathrm{cm})$ \\
\hline inch (in.) & 25.4 & millimeter $(\mathrm{mm})$ \\
\hline foot $(\mathrm{ft})$ & 0.3048 & meter $(\mathrm{m})$ \\
\hline mile (mi) & 1.609 & kilometer $(\mathrm{km})$ \\
\hline \multicolumn{3}{|c|}{ Area } \\
\hline acre & 4,047 & square meter $\left(\mathrm{m}^{2}\right)$ \\
\hline acre & 0.4047 & hectare (ha) \\
\hline acre & 0.4047 & square hectometer $\left(\mathrm{hm}^{2}\right)$ \\
\hline acre & 0.004047 & square kilometer $\left(\mathrm{km}^{2}\right)$ \\
\hline \multicolumn{3}{|c|}{ Volume } \\
\hline gallon (gal) & 0.003785 & cubic meter $\left(\mathrm{m}^{3}\right)$ \\
\hline gallon (gal) & 3.785 & cubic decimeter $\left(\mathrm{dm}^{3}\right)$ \\
\hline million gallons (Mgal) & 3,785 & cubic meter $\left(\mathrm{m}^{3}\right)$ \\
\hline \multicolumn{3}{|c|}{ Flow rate } \\
\hline acre-foot per year (acre-ft/yr) & 1,233 & cubic meter per year $\left(\mathrm{m}^{3} / \mathrm{yr}\right)$ \\
\hline acre-foot per year (acre-ft/yr) & 0.001233 & $\begin{array}{l}\text { cubic hectometer per year }\left(\mathrm{hm}^{3} /\right. \\
\text { yr })\end{array}$ \\
\hline foot per day (ft/d) & 0.3048 & meter per day $(\mathrm{m} / \mathrm{d})$ \\
\hline cubic foot per second $\left(\mathrm{ft}^{3} / \mathrm{s}\right)$ & 0.02832 & cubic meter per second $\left(\mathrm{m}^{3} / \mathrm{s}\right)$ \\
\hline gallon per minute (gal/min) & 0.06309 & liter per second $(\mathrm{L} / \mathrm{s})$ \\
\hline gallon per day (gal/d) & 0.003785 & cubic meter per day $\left(\mathrm{m}^{3} / \mathrm{d}\right)$ \\
\hline million gallons per day (Mgal/d) & 0.04381 & cubic meter per second $\left(\mathrm{m}^{3} / \mathrm{s}\right)$ \\
\hline inch per year (in/yr) & 25.4 & millimeter per year $(\mathrm{mm} / \mathrm{yr})$ \\
\hline \multicolumn{3}{|c|}{ Hydraulic conductivity } \\
\hline foot per day (ft/d) & 0.3048 & meter per day $(\mathrm{m} / \mathrm{d})$ \\
\hline \multicolumn{3}{|c|}{ Hydraulic gradient } \\
\hline foot per foot $(\mathrm{ft} / \mathrm{ft})$ & 1 & meter per meter $(\mathrm{m} / \mathrm{m})$ \\
\hline
\end{tabular}

Temperature in degrees Celsius $\left({ }^{\circ} \mathrm{C}\right)$ may be converted to degrees Fahrenheit $\left({ }^{\circ} \mathrm{F}\right)$ as follows:

$$
{ }^{\circ} \mathrm{F}=\left(1.8 \times{ }^{\circ} \mathrm{C}\right)+32
$$

\section{Datum}

Vertical coordinate information is referenced to the North American Vertical Datum of 1988 (NAVD 88).

Horizontal coordinate information is referenced to the North American Datum of 1983 (NAD 83).

Elevation, as used in this report, refers to distance above the vertical datum. 


\section{Abbreviations}

$\begin{array}{ll}\text { GIS } & \text { geographic information system } \\ \text { GPS } & \text { global positioning system } \\ \text { LPNNRD } & \text { Lower Platte North Natural Resources District } \\ \text { MUD } & \text { Omaha Metropolitan Utilities District } \\ \text { NRD } & \text { Natural Resources District } \\ \text { NWIS } & \text { National Water Information System } \\ \text { PMRNRD } & \text { Papio-Missouri River Natural Resources District } \\ \text { RMSE } & \text { root mean square error } \\ \text { RTK } & \text { real-time kinematic } \\ \text { RTN } & \text { real-time network } \\ \text { TIR } & \text { thermal infrared } \\ \text { USGS } & \text { U.S. Geological Survey } \\ \text { VFLUX } & \text { Vertical Fluid Heat Transfer Solver }\end{array}$

\section{Acknowledgments}

We thank Daryl Andersen and Russ Oaklund of the Lower Platte North Natural Resources District for assistance with water-level measurements, well owner coordination, and local expertise. We also thank Kevin Tobin of the Metropolitan Utilities District for providing groundwaterlevel data and site access. We thank Jamie Bednar, City of Waterloo, for allowing access to the Elkhorn River through city property. We also thank landowners for graciously allowing access to their property during data collection. Funding for this study was provided in part by the Nebraska Department of Natural Resources INSIGHT Data Enhancement Program and the Nebraska Natural Resources Commission Water Sustainability Fund. 


\title{
Groundwater Movement and Interaction with Surface Water near the Confluence of the Platte and Elkhorn Rivers, Nebraska, 2016-18
}

\author{
By Christopher M. Hobza, ${ }^{1}$ Mason J. Johnson, ${ }^{1}$ Paul W. Woodward ${ }^{2}$ Kellan R. Strauch, ${ }^{1}$ and \\ Aaron R. Schepers ${ }^{3}$
}

\section{Abstract}

The State of Nebraska requires a sustainable balance between long-term water supplies and uses of groundwater and surface water and requires Natural Resources Districts to include the effect of groundwater use on surface-water systems as part of their respective integrated management plans. Recent droughts in Nebraska (2000-6; 2012-13) have amplified concerns about the long-term sustainability of groundwater and surface-water resources in the state, and concerns about the effect of groundwater irrigation on both streamflow and the water supplies needed to meet wildlife, recreational, and municipal needs. The lower Platte River provides nearly 100 percent of drinking-water supplies to Lincoln, Nebraska, 40 to 60 percent of drinking-water supplies to Omaha, Nebr., and critical aquatic and riparian habitat for threatened and endangered species. The Lower Platte River Basin-wide Management Plan has been jointly developed by the Nebraska Department of Natural Resources and seven Natural Resources Districts to address some of these concerns by managing groundwater and surface-water resources conjunctively.

To sustain flows in the lower Platte River that are needed for municipal water supplies, water managers have proposed projects aimed at temporary storage of surface water in upstream parts of the basin to mitigate periods of low flow in the lower Platte River. To increase scientific understanding and provide support for any potential future streamflow augmentation projects, the Papio-Missouri River Natural Resources District, the Lower Platte North Natural Resources District, and the Nebraska Department of Natural Resources, in cooperation with the U.S. Geological Survey, initiated this study to examine groundwater/surface-water interaction along the lower Platte and Elkhorn Rivers upstream from their confluence. The study design described herein focused

\footnotetext{
${ }^{1}$ U.S. Geological Survey.

${ }^{2}$ Papio-Missouri River Natural Resources District, Omaha, Nebraska.

${ }^{3}$ Cornerstone Mapping, Inc., Roca, Nebr.
}

on understanding seasonal characteristics of groundwater movement and interaction with surface water during periods of high groundwater demand (June through August) and low groundwater demand (all other months). Understanding how groundwater movement and interaction with surface water are affected by streamflow conditions and local groundwater demand is critical to the development of any streamflow augmentation project intended to sustain streamflow and mitigate periods of low flow in the lower Platte River.

The characteristics of groundwater movement and interaction with surface water are affected by hydrologic and local climatic conditions. For the study area, 2016-18 conditions can be broadly characterized as above normal precipitation. The flows measured at the Elkhorn River at Waterloo, Nebr., streamflow-gaging station (U.S. Geological Survey station 06800500) were above the long-term median, and the streamflow of the Platte River near Leshara, Nebr., streamflowgaging station (06796500) remained normal or slightly above normal for the duration of this study.

Continuous streamflow and water-level data were interpreted to examine differences in groundwater movement and interaction with surface water between the Platte and Elkhorn Rivers during high and low groundwater demand periods. Although the streamflow for the Platte and Elkhorn Rivers and their tributaries was less during the high groundwater demand period, the hydraulic gradient along a transect of recorder wells was identical ( 0.0012 foot per foot) during the high and low groundwater demand synoptic water-level and streamflow surveys. The hydraulic gradient between the Platte and Elkhorn Rivers generally remained between 0.0011 and 0.0012 foot per foot. It can be inferred that the hydraulic gradient, which is the only temporally variable factor in Darcy's Law, is consistent throughout the study period and that groundwater flow does not vary appreciably along this transect.

The northern part of the study area (north of the transect of recorder wells) has consistent groundwater and tributary flow from Big Slough, Rawhide Creek (Old Channel), and Rawhide Creek for low and high groundwater demand 
periods. In the southern part of the study area (south of the transect of recorder wells), tributary flow is more variable and dependent on local groundwater demand and flow conditions of the Platte River. Small decreases (less than 2 feet) in the groundwater levels, such as those measured during the high groundwater demand period, can have substantial changes in the streamflow in an unnamed tributary to the Elkhorn River. The streamflow measured during the high groundwater demand synoptic water-level and streamflow survey had decreased by nearly a factor of 20 when compared to the low groundwater demand period.

The volume of groundwater discharge received by the Elkhorn River was estimated by examining the changes in streamflow between measurement locations. Streamflow measurements indicate that the groundwater discharge received by the Elkhorn River in the southern part of the study area was seasonably variable, making it difficult if not impossible to estimate an annual value. In the Elkhorn River, between the Elkhorn River at Waterloo, Nebr., streamflow-gaging station and the Q Street Bridge, streamflow measurements collected during the low groundwater demand period indicated a gain of 80 cubic feet per second, which is comparable to the gain estimated using aerial thermal infrared imagery and water temperature data. Streamflow measurements collected during the high groundwater demand period indicate a loss of 80 cubic feet per second across this same reach. In assessing water supply conditions in the lower Platte River system, the term "loss" in reference to streamflow in the Elkhorn River should be used with caution. Most likely, flow from the Elkhorn River which is "lost" to the groundwater system will later discharge to surface water closer to the confluence of the Platte and Elkhorn Rivers as underflow. A calibrated groundwater flow model of the study area likely is required to predict the fate of this water and to quantify groundwater discharge during varying hydrologic conditions along this reach.

Aerial thermal infrared imagery indicated that much of the groundwater discharge in the southern part of the study area is focused across a 3-mile reach where the Elkhorn River turns southwest, perpendicular to the regional groundwater flow direction. Points of focused groundwater discharge were not detected with aerial thermal infrared imagery, indicating that groundwater discharge is diffuse rather than concentrated at focused points. Temperature-based streambed flux estimates indicated that strong regional groundwater gradients are not driving groundwater discharge and hyporheic flow is the dominant groundwater/surface-water exchange process.

\section{Introduction}

The State of Nebraska requires a sustainable balance between long-term water supplies and uses of groundwater and surface water and requires Natural Resources Districts (NRDs) to include the effect of groundwater use on surface-water systems as part of their respective integrated management plans. Recent droughts in Nebraska (2000-6; 2012-13) have amplified concerns about the long-term sustainability of groundwater and surface-water resources in Nebraska, as well as concerns about the effect of groundwater irrigation on streamflow and water supplies needed to meet wildlife, recreational, and municipal needs. The Platte River is an important stream reach that provides nearly 100 percent of drinking-water supplies to Lincoln, Nebraska, 40 to 60 percent of drinking-water supplies to Omaha, Nebr. (fig. 1), and critical aquatic and riparian habitat for threatened and endangered species (Lower Platte River Basin Coalition, 2018). The Lower Platte River Basin-wide Management Plan (Lower Platte River Basin Coalition, 2018) has been developed jointly by the Nebraska Department of Natural Resources and seven NRDs to address some of these concerns by managing groundwater and surface-water resources conjunctively.

To sustain flows in the lower Platte River that are needed for municipal water supplies, water managers have proposed projects aimed at temporary storage of surface water in upstream parts of the basin to mitigate periods of low flow in the lower Platte River. One area of interest to the Lower Platte North NRD (LPNNRD) and the Papio-Missouri River NRD (PMRNRD) is a reach of the lower Platte River that extends downstream from Fremont, Nebr., to its confluence with the Elkhorn River (fig. 1). Along this 23-mile (mi) reach, the Platte River is topographically higher in elevation than the Elkhorn River and a broad, flat alluvial valley separates the two streams. Within the study area, the Platte River has a gradient of approximately 4.4 feet per mile and the Elkhorn River flows for approximately $24 \mathrm{mi}$ at a gradient of 2.5 feet per mile (fig. 1). Because of the differences in stream gradient, the Platte River's bed at the Platte River at Leshara, Nebr., streamflow-gaging station (U.S. Geological Survey [USGS] station 06796500) is roughly 40 feet (ft) higher in elevation than the Elkhorn River streambed at the Elkhorn River at Waterloo, Nebr., streamflow-gaging station (USGS station 06800500). It can be inferred that water recharged from the Platte River into the alluvial aquifer will move downgradient to the Elkhorn River, increasing base flows therein, but the effects of varying flow in the Platte and Elkhorn Rivers, water levels in the alluvial aquifer, and local climatic conditions on the hydrologic system have not been evaluated. Understanding how the hydrologic systems respond to fluctuations in groundwater levels and surface water flow is critical to planning any proposed streamflow retiming or augmentation project to mitigate periods of low flow in the Platte River.

Flows in the lower Platte River are heavily dependent on climatic conditions in the local area and upstream. The influence of several hydrologic factors - such as increased flows during the spring in the Platte River caused by above-normal snowmelt, runoff to the Elkhorn River, or local groundwater demand - may affect the groundwater flow paths in the alluvial aquifer and produce changes in the base flow of the Elkhorn River. To increase scientific understanding and provide support for any potential future streamflow augmentation 


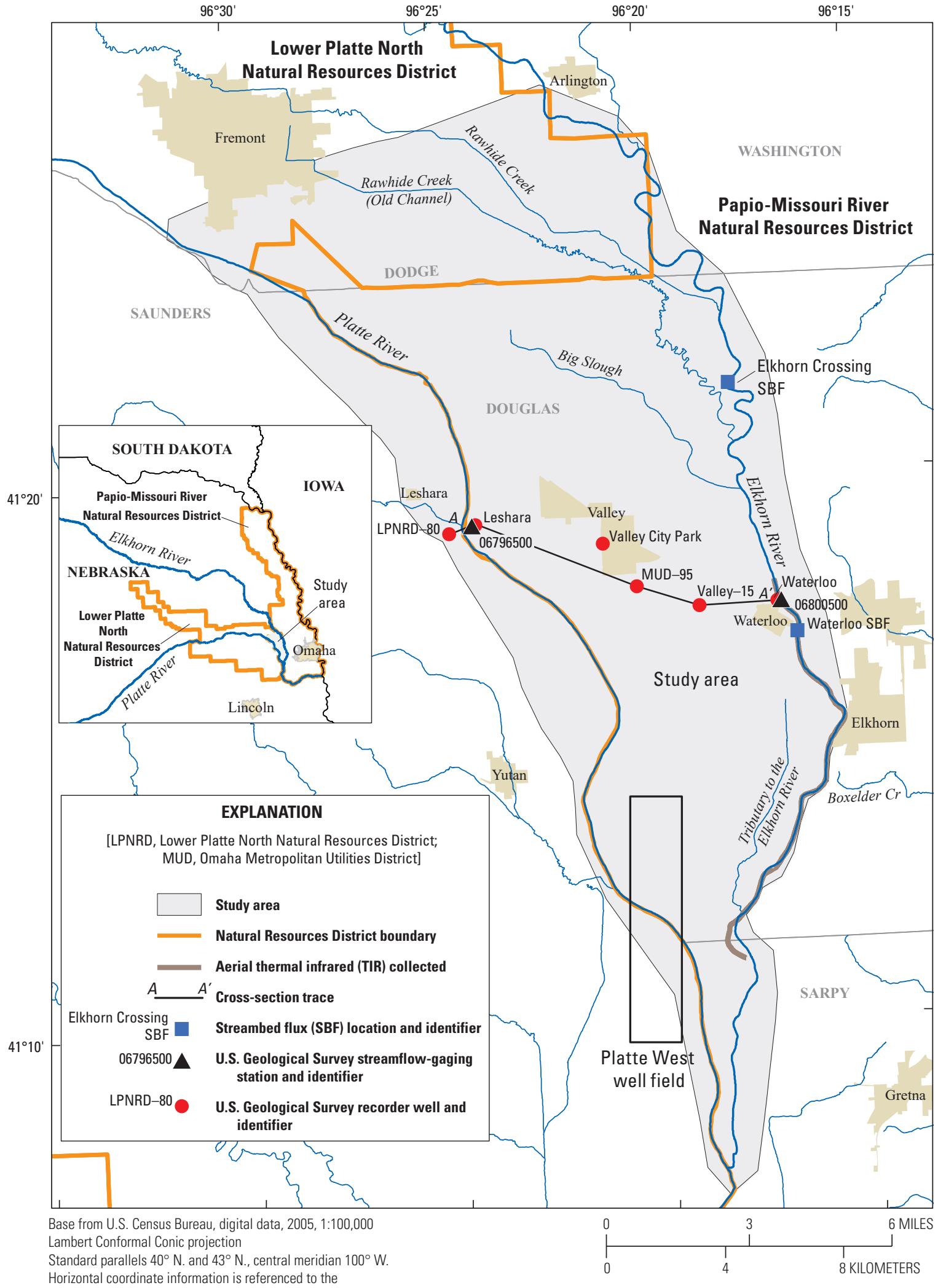

Horizontal coordinate information is referenced to the

North American Datum of 1983 (NAD 83)

Figure 1. Selected stream reaches, streamflow-gaging stations, recorder wells, and cross-section trace upstream from the confluence of the Platte and Elkhorn Rivers, Nebraska. 
projects, the PMRNRD, LPNNRD, and Nebraska Department of Natural Resources, in cooperation with the USGS, examined the groundwater/surface-water interaction along the lower Platte and Elkhorn Rivers upstream from their confluence. The study design described herein focused on understanding seasonal characteristics of groundwater movement and interaction with surface water during periods of high-groundwater demand (June through August) and low groundwater demand (all other months) from 2016 to 2018. Understanding how groundwater movement and interaction with surface water are affected by streamflow conditions and local groundwater demand are critical to the development of any streamflow augmentation project intended to sustain streamflow and mitigate periods of low flow in the lower Platte River.

\section{Purpose and Scope}

The purpose of this report is to describe the spatial and temporal characteristics of groundwater movement and interaction with surface water near the lower Platte and Elkhorn Rivers upstream from their confluence (fig. 1) during high and low groundwater demand periods. This report documents the methods of data collection and analysis, which include the collection of continuous groundwater and surface-water level elevation data along a transect from the Platte River to the Elkhorn River from May 2016 through September 2018. This report also provides water-level and streamflow data and interpretations from two synoptic water-level and streamflow surveys completed during high and low groundwater demand periods from May 2016 through September 2018. During the high groundwater demand period in 2017, temperature-based streambed flux estimates from July to September 2017 are also provided to improve the understanding of the temporal and spatial variability of groundwater/surface-water interaction along the Elkhorn River. Aerial thermal infrared (TIR) imagery was collected during a low groundwater demand period in December of 2017 to assess the spatial variability of groundwater/surface-water interaction along the Elkhorn River. The data and interpretations are intended to inform water managers of the effect flow conditions have on groundwater movement and interaction with surface water above the confluence of the Platte and Elkhorn Rivers.

\section{Study Area Description}

The study area includes portions of Douglas, Dodge, Sarpy, Saunders, and Washington Counties (fig. 1). Most of the study area is within the PMRNRD and the remaining is within the LPNNRD (fig. 1). The western edge of the study area extends west of the Platte River to include a part of the Platte River Valley. The eastern edge of the study area is along the eastern edge of the Elkhorn River Valley bounded by the valley wall near the edge of the Papillion Creek Basin (not shown on any maps). Between the Platte and Elkhorn Rivers, the study area is a nearly flat valley (Conservation and Survey Division, University of Nebraska-Lincoln, 2018b) that is gently sloping towards the Elkhorn River. The area is drained by Rawhide Creek, Rawhide Creek (Old Channel), and Big Slough to the north and an unnamed tributary to the Elkhorn River (referred to herein as "Tributary to the Elkhorn River") to the south (fig. 1).

The climate in the study area is typical of continental midlatitude locations, characterized by cold winters and warm summers (McGuire and others, 2012). At Valley, Nebr., from 1981 to 2010 the average annual low temperature for the winter was -3.6 degrees Celsius $\left({ }^{\circ} \mathrm{C}\right)$ and the average annual high temperature for the summer was $28.9^{\circ} \mathrm{C}$ (National Center for Environmental Information, 2018; fig. 1). During that same period, the average annual precipitation was 32.6 inches (in.) per year (National Center for Environmental Information, 2018), 13.6 in. of which on average falls during the summer months (June through August). Nearly 75 percent of the annual precipitation falls within the growing season for row crops, which is defined as April through September. Potential evaporation, like precipitation, is greatest during the cropgrowing season of April through September.

Much of the land used within the study area is for agricultural purposes (Center for Advanced Land Management Information Technologies, 2007). Approximately 22 percent of the study area is classified as irrigated cropland, 37 percent dryland crops, 19 percent pasture, 11 percent riparian woodlands, 6 percent open water or wetlands, and 5 percent urban or developed. Increased urban and residential development has decreased the percent of agricultural land in production (Papio-Missouri River Natural Resources District, 2017a).

Within the study area, groundwater primarily is used for domestic, irrigation, and public water supply (Maupin and others, 2014). Because water-use data are reported on a countywide level, numbers specific to the study area are not reported. Countywide estimates (Maupin and others, 2014; Kenny and others, 2009) indicate that water use has been decreasing within the PMRNRD, which is potentially in response to increased urbanization and increased water use efficiency (Papio-Missouri River Natural Resources District, 2017a). McGuire and others (2012) reported that highest uses of groundwater in Douglas County were for domestic and public water supply. Since then, the Omaha Metropolitan Utilities District (MUD) has opened the Platte West Well Field, which includes 42 production wells on 2,240 acres. The Platte West Well Field is north and south of the Platte River in Douglas and Saunders Counties (fig. 1). Since pumping began in February 2009, the average water use for the well field was 28.5 million gallons per day (Mgal/d). Approximately 70 percent of the total pumping is on the Saunders County side of the well field outside of the study area (Burns and McDonnell Engineering Company, Inc., 2017). 


\section{Hydrogeology}

The local hydrogeology and aquifers of the study area have been described in geologic maps (Burchett and others, 1975), cross-sections (Korus and others, 2012), test hole information (Conservation and Survey Division, University of Nebraska-Lincoln, 2018a), and airborne electromagnetic surveys (Carney and others, 2015). McGuire and others (2012) and Verstraeten and Ellis (1995) have described the groundwater quality conditions of the surficial and bedrock aquifers within the PMRNRD. Olsson Associates (2009) delineated and described the surficial aquifers across the LPNNRD, which includes the northern and western part of the study area.

The primary aquifer consists of Quaternary-age alluvial deposits that mantle nearly the entire study area. Within the PMRNRD, these deposits are referred to as the Elkhorn River Valley aquifer (McGuire and others, 2012; Verstraeten and Ellis, 1995) and in the LPNNRD to the north they are referred to as the Platte Valley aquifer (Olsson Associates, 2009). Most of the deposits in the surficial aquifer consist of coarse-grained alluvial deposits beneath flood plain and terrace deposits along the Elkhorn and Platte River Valleys. Most of these deposits are permeable sand and gravel nearly $100 \mathrm{ft}$ thick with interbedded clay and silt (McGuire and others, 2012; Olsson Associates, 2009; Papio-Missouri River Natural Resources District, 2017b). The thicker portions of the Quaternary-age alluvial deposits are along the eastern edge of the Platte River in Douglas and Sarpy Counties. The Quaternary-age alluvial deposits thin near the Elkhorn River, particularly in the northern part of the study area. Thinning of the Quaternaryage alluvial deposits can be seen in map view (Papio-Missouri River Natural Resources District, 2017b) and cross-section view (Carney and others; 2015; Korus and others, 2012). The highest concentration of high-capacity wells is northwest of Valley, Nebr. (Papio-Missouri River Natural Resources District, 2017b). These wells typically yield 700 to 1,200 gallons per minute (gal/min; Verstraeten and Ellis, 1995).

The early Cretaceous-age Dakota Formation (referred to as the Dakota Group in Korus and Joeckel, 2011) underlies the Quaternary-age alluvial deposits across the entire study area. Within the PMRNRD, the Dakota Formation is described as sandstone and claystone or mudstone. The sandstone is described as very fine to coarse grained, friable, and cemented with iron oxide (Verstraeten and Ellis, 1995). The claystone is massive and often silty. The Dakota Formation aquifer is typically confined or partially confined. Well yield depends on the thickness of the sandstone and ranges from 10 to $600 \mathrm{gal} / \mathrm{min}$. A test hole was drilled through the Dakota Formation in March 2016 in Valley, Nebr. (labeled Valley City Park in fig. 1). In this location, the upper $95 \mathrm{ft}$ was described as mudstone that overlies approximately $24 \mathrm{ft}$ of sandstone. Observation wells were installed in Valley City Park (table 1) and screened within the Quaternary-age alluvial deposits (USGS stations
411845096211201 and 411845096211202 ) or the sandstone interval of the underlying Dakota Formation (USGS station 411845096211203). Measured water levels in the Valley Park deep well (411845096211203; U.S. Geological Survey, 2018a) indicated that the upper mudstone created artesian conditions within the Dakota Formation.

The interaction of groundwater and surface water along the Platte and Elkhorn Rivers has been the topic of several published studies. Verstraeten and Ellis (1995) noted that the alluvial aquifer can recharge from the adjacent Elkhorn and Platte Rivers when river stage is higher than groundwater levels. Most of the published work focused on the hydraulic properties of streambed sediments and the shallow underlying aquifer (Cheng and others, 2011; Chen, 2005). As part of an unpublished groundwater model examining effects of groundwater pumping on streamflow of the Platte River within the LPNNRD (X. Chen and G. Ou, University of Nebraska-Lincoln, written commun., 2012), in-stream permeameter tests were completed in the shallow streambed and lab permeameter tests were conducted from extracted cores from depths as much as $50 \mathrm{ft}$. Core locations near Fremont and Yutan (fig. 1) generally indicated that approximately $14 \mathrm{ft}$ of permeable sand and gravel overlies a thicker fine-grained layer that could limit interaction with the Quaternary-age alluvial aquifer, though the lateral extent of the fine-grained layer was not discussed in detail in the report. Other studies (Cheng and others, 2011; Chen, 2005) described the spatial patterns of vertical hydraulic conductivity of streambed sediments along a nearly 200-mi reach of the Platte River. Researchers (Cheng and others, 2011) indicated there were decreases in the vertical hydraulic conductivity of the streambed sediments of the Platte River downstream from the Loup River (not shown on any maps), which drains the Sand Hills and dissected loess plains in central Nebraska, and the Elkhorn River, which drains glaciated parts of northeastern Nebraska. The contributions of fine-grained sediment from the Loup and Elkhorn Rivers result in lower vertical hydraulic conductivity, potentially limiting the interaction potential of the Platte River within parts of the studied stream reaches (Cheng and others, 2011).

Similar studies have focused on understanding groundwater/surface-water interaction along the Elkhorn River upstream from the study area (Chen and others, 2009; Song and others, 2009). Studies of the Elkhorn River and the underlying alluvial aquifer upstream from the study area determined vertical hydraulic conductivity and hydraulic gradients can vary substantially over very short distances. Over distances of less than $50 \mathrm{ft}$, the vertical hydraulic gradient often switched from positive (groundwater discharge) to negative (groundwater recharge). The researchers attributed this to groundwater/surface-water exchange processes happening primarily within the hyporheic zone rather than being driven by regional groundwater flow gradients (Chen and others, 2009). 
Table 1. Site number, geographic location, and selected well construction data for observation wells drilled near streamflow-gaging stations and recorder wells.

[NAVD 88, North American Vertical Datum of 1988; aquifer screened, the aquifer where the well is screened; T, township; N, north; R, range; E, East; S, section; ABCD, codes for the quarter section, quarterquarter section, quarter-quarter-quarter section, and quarter-quarter-quarter-quarter sections $\mathrm{A}, \mathrm{B}, \mathrm{C}$, and D, respectively, where $\mathrm{A}$ is the northeast, B is the northwest, C is the southwest, and D is the southeast quarter of the next larger unit; LPNNRD, Lower Platte North Natural Resources District; alluvial, Quaternary-age Elkhorn River Valley alluvial aquifer; Dakota, sandstone interval within the early Cretaceousage Dakota Formation; MUD, Omaha Metropolitan Utilities District]

\begin{tabular}{|c|c|c|c|c|c|c|c|c|c|c|}
\hline Site number & Station name & Field name & $\begin{array}{c}\text { Latitude, } \\
\text { in degrees, } \\
\text { minutes, } \\
\text { seconds }\end{array}$ & $\begin{array}{c}\text { Longitude, } \\
\text { in degrees, } \\
\text { minutes, } \\
\text { seconds }\end{array}$ & Northing & Easting & $\begin{array}{c}\text { Surveyed } \\
\text { elevation, } \\
\text { in feet above } \\
\text { NAVD } 88\end{array}$ & $\begin{array}{c}\text { Screened } \\
\text { interval, } \\
\text { in feet below } \\
\text { land surface }\end{array}$ & $\begin{array}{l}\text { Date } \\
\text { drilled }\end{array}$ & $\begin{array}{c}\text { Aquifer } \\
\text { screened }\end{array}$ \\
\hline 411903096245501 & T16N R9E S33ABCD1 & LPNNRD-80 & $41^{\circ} 19^{\prime} 02.6^{\prime \prime}$ & $96^{\circ} 24^{\prime} 54.6^{\prime \prime}$ & 560981.9 & 2624581.3 & $1,158.87$ & $60-80$ & $7 / 7 / 2014$ & Alluvial. \\
\hline 411911096241601 & T16N R9E S34BBBD1 & Leshara & $41^{\circ} 19^{\prime} 11.00^{\prime \prime}$ & $96^{\circ} 24^{\prime} 16.00^{\prime \prime}$ & 561953.2 & 2627482.5 & $1,153.50$ & $24.7-34.7$ & $5 / 24 / 2016$ & Alluvial. \\
\hline 411845096211201 & T16N R9E S36NESE & Valley City Park & $41^{\circ} 18^{\prime} 45.26^{\prime \prime}$ & $96^{\circ} 21^{\prime} 12.00^{\prime \prime}$ & 527845.4 & 2656120.5 & $1,140.00$ & $20-30$ & $4 / 27 / 2017$ & Alluvial. \\
\hline 411845096211202 & T16N R9E S36NESE & $\begin{array}{l}\text { Valley City Park } \\
\text { medium }\end{array}$ & $41^{\circ} 18^{\prime} 45^{\prime \prime}$ & $96^{\circ} 21^{\prime} 12^{\prime \prime}$ & 527845.0 & 2656121.0 & $1,140.00$ & $84-94$ & $5 / 10 / 2017$ & Alluvial. \\
\hline 411845096211203 & T16N R9E S36NESE & $\begin{array}{l}\text { Valley City Park } \\
\text { deep }\end{array}$ & $41^{\circ} 18^{\prime} 45^{\prime \prime}$ & $96^{\circ} 21^{\prime} 12^{\prime \prime}$ & 527845.0 & 2656121.0 & $1,140.00$ & 194-204 & $5 / 10 / 2017$ & Dakota. \\
\hline 411757096202501 & T15N R10E S6ACCC1 & MUD-95 & $41^{\circ} 17^{\prime} 57^{\prime \prime}$ & $96^{\circ} 20^{\prime} 25^{\prime \prime}$ & 555211.7 & 2645404.1 & $1,136.49$ & $5-15,45-55$ & $1 / 25 / 1990$ & Alluvial. \\
\hline 411733096185501 & T15N R10E S5DDCB1 & Valley-15 & $41^{\circ} 17^{\prime} 33.32^{\prime \prime}$ & $96^{\circ} 18^{\prime} 55.07^{\prime \prime}$ & 553109.3 & 2652361.9 & $1,127.40$ & $10-15$ & $8 / 27 / 2002$ & Alluvial. \\
\hline 411736096170201 & T15N R10E S3CDDA1 & Waterloo & $41^{\circ} 17^{\prime} 35.6^{\prime \prime}$ & $96^{\circ} 17^{\prime} 01.5^{\prime \prime}$ & 553710.6 & 2661010.6 & $1,121.93$ & $34.7-44.2$ & $3 / 12 / 2014$ & Alluvial. \\
\hline
\end{tabular}




\section{Approach and Methods}

This section of the report describes the methods of data collection and analysis used to improve the understanding of groundwater movement and interaction with surface water near the confluence of the Platte and Elkhorn Rivers. The "Approach and Methods" section is divided into four different subsections. The "Real-Time Water-Level Network" subsection describes the continuous water-level data collection procedures used to assess groundwater movement and interaction with surface water along a northwest-southeast transect of the study area. The "Synoptic Water-Level and Streamflow Survey" subsection describes the data collection methods and interpretive approaches used to determine the groundwater flow directions and streamflow during high and low groundwater demand periods. The "Aerial Thermal Infrared Imagery Methods" subsection provides background information of aerial TIR, describes the data collection methods, and discusses the interpretive approach used to describe the spatial characteristics of groundwater discharge to the Elkhorn River during a low groundwater demand period. The "TemperatureBased Streambed Flux Estimates" subsection describes the data collection approach and analytical methods used to estimate groundwater/surface-water exchange at locations along the Elkhorn River during a high groundwater demand period.

\section{Real-Time Water-Level Network}

Continuous water levels of groundwater and surface water were collected and interpreted to understand the temporal variability of groundwater/surface-water interaction above the confluence of the lower Platte and Elkhorn Rivers. Continuous groundwater-level data were collected during the period of June 2016 through September 2018 in five recorder wells located along a transect between two USGS streamflowgaging stations: the Platte River near Leshara, Nebr. (USGS station 06796500), and Elkhorn River at Waterloo, Nebr. (USGS station 06800500) (fig. 1; table 2). A cross-section of the transect using recently acquired elevation data (Nebraska Department of Natural Resources, 2011) can be seen in figure 2. One monitoring well (USGS station 411845096211201, also called Valley City Park) was installed within this transect in April 2017 and began collecting groundwater-level data in June 2017 (fig. 1; table 1).

Groundwater and surface-water elevations were collected and compared at the Platte River near Leshara, Nebr. (USGS station 06796500), and Elkhorn River at Waterloo, Nebr. (USGS station 06800500), streamflow-gaging stations (fig. 1) to quantify the difference in hydraulic head between the groundwater and surface water. The data collection approach, described in Eddy-Miller and others (2012), consists of a streamflow-gaging station coupled with an observation well generally within $100 \mathrm{ft}$ of the river, completed below the elevation of the streambed, and instrumented with a continuous water-level recorder. The comparison of continuous groundwater-level elevation and stream-stage elevation can indicate whether a stream is gaining or losing near the streamflow-gaging station. The information provided by multiple instrumented streamflow-gaging stations coupled with nearby recorder wells allows for an analysis of groundwater discharge patterns, temporally and spatially (EddyMiller and others, 2012).

To compare measured groundwater and surface-water levels at the same datum, elevations of monitoring wells and streamflow-gaging station datums were established by using the Global Navigation Satellite Systems followed by a series of station levels (Kenney, 2010). Elevations were established using the single-base real-time kinematic (RTK) approach described in Rydlund and Densmore (2012). Data collection procedures ensured that the position and elevation accuracy met the criteria for a USGS Level II single-base RTK survey (Rydlund and Densmore, 2012). The vertical accuracy generally was within $0.15 \mathrm{ft}$ for each observation well.

Station levels were completed to establish the measuring point on the well casing and to tie the streamflow-gaging station datum to the surveyed reference mark elevation on the concrete well pad. Station levels were completed using a Sokkia SDL30 electronic digital level system (Sokkia Topcon Co., Ltd., 2000) in accordance with the guidelines and procedures stated in Cunningham and Schalk (2011) and Kenney (2010).

All observation wells were instrumented with a KPSI 500 vented pressure transducer (TE Connectivity, 2018), which was placed below the anticipated water level in the well. All water-level data were collected following the protocols and guidance stated in Cunningham and Schalk (2011) and Turnipseed and Sauer (2010) and are stored in the USGS National Water Information System (NWIS) database (U.S. Geological Survey, 2018a).

\section{Synoptic Water-Level and Streamflow Survey}

The PMRNRD and LPNNRD have been collecting groundwater-level data within the study area for monitoring and management purposes for decades. Discrete or continuous-recorder measurements are invaluable for water management but do not provide sufficient detailed information to determine groundwater flow paths under various hydrologic conditions. To improve the understanding of groundwater movement and interaction with surface water under varying hydrologic conditions, two synoptic water-level and streamflow surveys were completed during a low groundwater demand period (October 31-November 3, 2016) and a high groundwater demand period (July 31-August 2, 2017). To provide an accurate snapshot of hydrologic conditions, all data were collected during a short period (less than 1 week). During that same period, streamflow measurements were collected at various bridge crossings along the Elkhorn River and selected tributaries. The water-level elevation data, along with supporting streamflow measurements, were used to create groundwater-level contour maps from which groundwaterflow paths can be interpreted. 


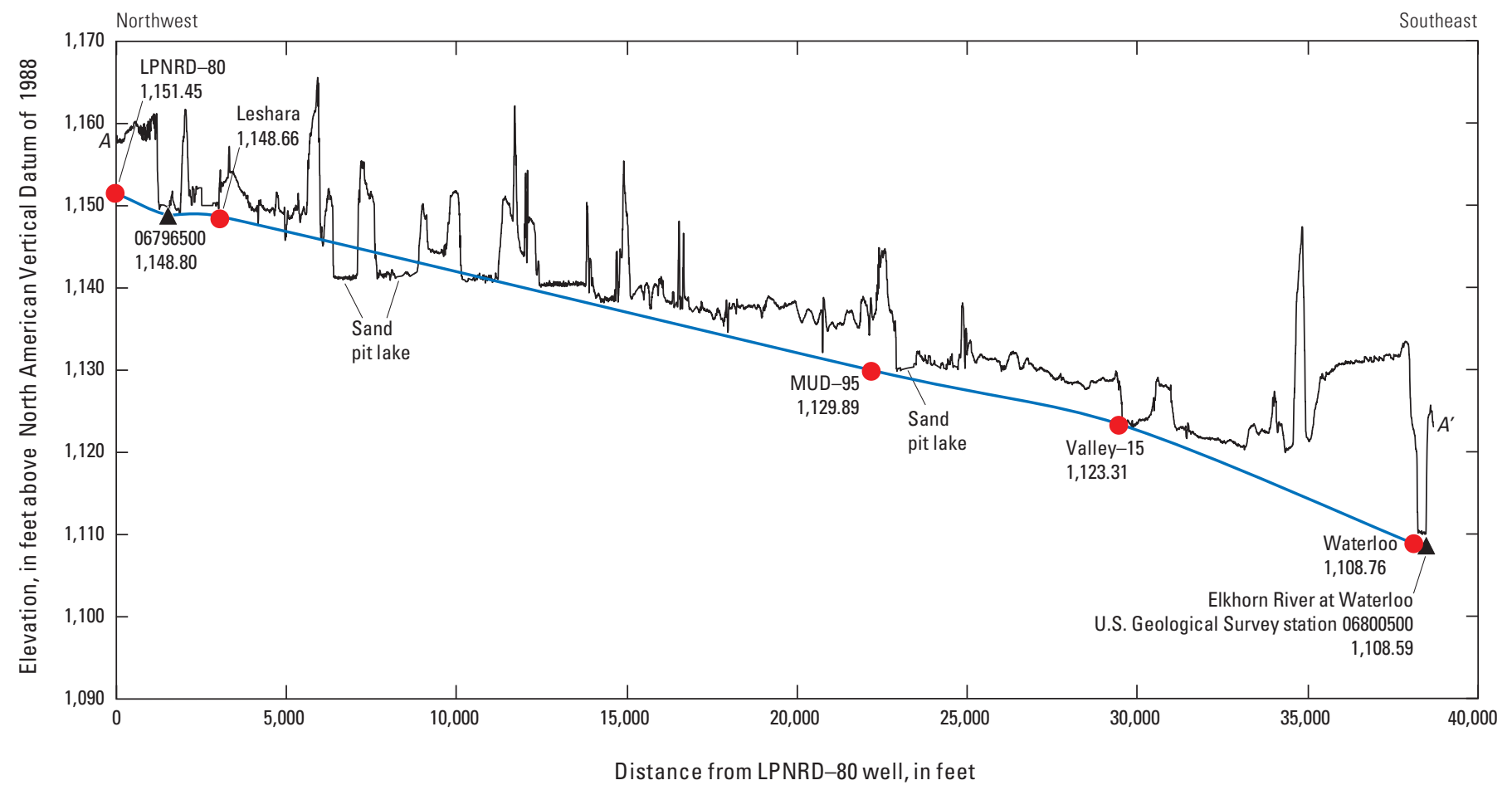

EXPLANATION

[LPNRD, Lower Platte North Natural Resources District; MUD, Omaha Metropolitan Utilities District]

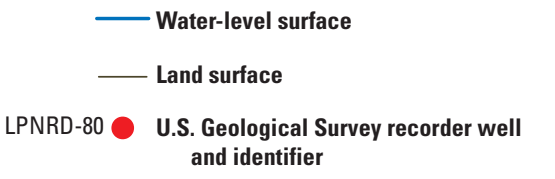

06796500 A U.S. Geological Survey streamflow-gaging station and identifier

Figure 2. Cross-section of study area showing water-levels measured in recorder wells and streamflow-gaging stations from November 2016.

The PMRNRD, LPNNRD, and MUD routinely measure groundwater levels in observation, domestic, and irrigation wells as part of their groundwater-monitoring programs. For this study, many of these wells were selected for use in the synoptic water-level and streamflow surveys because the wells were screened in the Quaternary-age alluvial aquifer, easily accessible, and evenly distributed across the study area. Prior to the synoptic water-level and streamflow surveys, the elevations of the selected wells were surveyed using the single-base RTK approach to achieve a Level-II survey accuracy (Rydlund and Densmore, 2012). During synoptic water-level and streamflow surveys, a groundwater-level measurement was obtained for each well from measurements by PMRNRD and LPNNRD staff or by transducers in recorder wells (USGS, 2018a; Kevin Tobin, Omaha Metropolitan Utilities District, written commun., 2018). The daily median groundwater level was computed from the hourly recorded measurements, and the groundwater elevation was computed from the daily median groundwater level and the reference mark elevation on the well and used in low groundwater demand and high groundwater demand synoptic water-level and streamflow surveys.

Surface-water features - such as streams, ponds, sand pit lakes, wetlands, and inundated road ditches - are common within the study area. Because groundwater is close to land surface (within $10 \mathrm{ft}$ ), these surface-water features are considered in hydrologic connection with the local groundwater flow system. The elevations of surface-water features were surveyed with a rover receiver using a real-time network (RTN; U.S. Geological Survey, 2018b), where the rover receiver receives real-time position corrections from a central server through a mobile wireless fidelity (commonly known as Wi-Fi) hotspot linked to the rover receiver. Data collection procedures ensured that positions and elevations achieved a USGS Level-IV survey accuracy (Rydlund and Densmore, 2012) and surveyed surface-water elevations were generally within $0.25 \mathrm{ft}$. 
Table 2. Measured streamflow and measurement locations collected during low and high groundwater demand synoptic water-level and streamflow surveys.

[Streamflow measurement quality rating: good (2-5 percent error), fair (5-8 percent error), and poor (greater than 8 percent error); lower bound of discharge, indicates the lower bound of the discharge based on the measurement quality rating and associated measurement error; upper bound of discharge, indicates the upper bound of the discharge based on the measurement quality rating and associated measurement error; discharge source, source of discharge data; $\mathrm{ft}^{3} / \mathrm{s}$, cubic foot per second; Nebr., Nebraska; DV, daily mean value of discharge reported at streamflow-gaging station; MEAS, discharge measured; St, Street; Cr, Creek; Old Ch, Old Channel; nr, near; Co, County; Rd, road; NE, northeast; N, north]

\begin{tabular}{|c|c|c|c|c|c|c|c|c|c|}
\hline Site number & Site name & $\begin{array}{l}\text { Latitiude, } \\
\text { in degrees, } \\
\text { minutes, } \\
\text { seconds }\end{array}$ & $\begin{array}{c}\text { Longitude, } \\
\text { in degrees, } \\
\text { minutes, } \\
\text { seconds }\end{array}$ & Date & $\begin{array}{l}\text { Discharge, } \\
\text { in } \mathrm{ft}^{3} / \mathrm{s}\end{array}$ & $\begin{array}{l}\text { Streamflow } \\
\text { measurement } \\
\text { quality rating }\end{array}$ & $\begin{array}{c}\text { Lower } \\
\text { bound of } \\
\text { discharge, } \\
\text { in } \mathrm{ft}^{3} / \mathrm{s}\end{array}$ & $\begin{array}{c}\text { Upper } \\
\text { bound of } \\
\text { discharge, } \\
\text { in } \mathrm{ft}^{3} / \mathrm{s}\end{array}$ & $\begin{array}{c}\text { Discharge } \\
\text { source }\end{array}$ \\
\hline \multirow[t]{2}{*}{06796500} & Platte River near Leshara, Nebr. & $41^{\circ} 19^{\prime} 12^{\prime \prime}$ & $96^{\circ} 24^{\prime} 14^{\prime \prime}$ & $11 / 2 / 2016$ & $4,940^{\mathrm{a}}$ & Fair & 4,540 & 5,340 & DV \\
\hline & & & & $8 / 2 / 2017$ & $2,320^{\mathrm{a}}$ & Fair & 2,130 & 2,510 & DV \\
\hline 412703096220801 & Elkhorn River at Arlington, Nebr. & $41^{\circ} 27^{\prime} 03$ & $96^{\circ} 22^{\prime} 08^{\prime \prime}$ & $8 / 2 / 2017$ & 1,060 & Fair & 975 & 1,140 & MEAS \\
\hline \multirow[t]{4}{*}{06800500} & Elkhorn River at Waterloo, Nebr. & $41^{\circ} 17^{\prime} 36^{\prime \prime}$ & $96^{\circ} 17^{\prime} 02^{\prime \prime}$ & $11 / 2 / 2016$ & $1,610^{\mathrm{a}}$ & Fair & 1,480 & 1,740 & DV \\
\hline & & & & $8 / 2 / 2017$ & $1,210^{\mathrm{a}}$ & Fair & 1,110 & 1,310 & DV \\
\hline & & & & $8 / 7 / 2017$ & 1,150 & Fair & 1,060 & 1,240 & MEAS \\
\hline & & & & $8 / 7 / 2017$ & 1,230 & Fair & 1,130 & 1,330 & MEAS \\
\hline \multirow[t]{3}{*}{06800800} & Elkhorn River at Q St Bridge near Venice, Nebr. & $41^{\circ} 12^{\prime} 17^{\prime \prime}$ & $96^{\circ} 17^{\prime} 46^{\prime \prime}$ & $11 / 2 / 2016$ & 1,690 & Fair & 1,550 & 1,830 & MEAS \\
\hline & & & & $8 / 2 / 2017$ & 1,130 & Fair & 1,040 & 1,220 & MEAS \\
\hline & & & & $8 / 7 / 2017$ & 1,080 & Fair & 1,030 & 1,170 & MEAS \\
\hline \multirow[t]{2}{*}{411951096184101} & Big Slough at 252nd Street near Valley, Nebr. & $41^{\circ} 19^{\prime} 51^{\prime \prime}$ & $96^{\circ} 18^{\prime} 41^{\prime \prime}$ & $11 / 2 / 2016$ & 6.13 & Good & 5.82 & 6.44 & MEAS \\
\hline & & & & $8 / 2 / 2017$ & 2.11 & Good & 2.00 & 2.22 & MEAS \\
\hline \multirow[t]{2}{*}{412146096205601} & Big Slough at 276th St near Valley, Nebr. & $41^{\circ} 21^{\prime} 46^{\prime \prime}$ & $96^{\circ} 20^{\prime} 56^{\prime \prime}$ & $11 / 2 / 2016$ & 2.75 & Good & 2.61 & 2.89 & MEAS \\
\hline & & & & $8 / 2 / 2017$ & 0.96 & Good & 0.91 & 1.01 & MEAS \\
\hline \multirow[t]{2}{*}{412408096220401} & Rawhide $\mathrm{Cr}$ (Old Ch) at 288th St nr Fremont, Nebr. & $41^{\circ} 24^{\prime} 08^{\prime \prime}$ & $96^{\circ} 22^{\prime} 04^{\prime \prime}$ & $11 / 2 / 2016$ & 22.5 & Good & 21.4 & 23.6 & MEAS \\
\hline & & & & $8 / 2 / 2017$ & 21.7 & Good & 20.6 & 22.8 & MEAS \\
\hline \multirow[t]{2}{*}{412521096253101} & Rawhide $\mathrm{Cr}$ (Old Ch) at Co Rd 26 at Fremont, Nebr. & $41^{\circ} 25^{\prime} 21^{\prime \prime}$ & $96^{\circ} 25^{\prime} 31^{\prime \prime}$ & $11 / 3 / 2016$ & 30.9 & Good & 29.3 & 32.4 & MEAS \\
\hline & & & & $8 / 2 / 2017$ & 25.9 & Good & 24.6 & 27.2 & MEAS \\
\hline \multirow[t]{2}{*}{412100096181701} & Rawhide $\mathrm{Cr}$ (Old Ch) at Rainwood Rd nr Valley, NE & $41^{\circ} 21^{\prime} 00^{\prime \prime}$ & $96^{\circ} 18^{\prime} 17^{\prime \prime}$ & $11 / 2 / 2016$ & 30.2 & Good & 28.7 & 31.7 & MEAS \\
\hline & & & & $8 / 2 / 2017$ & 31.1 & Good & 29.5 & 32.7 & MEAS \\
\hline \multirow[t]{2}{*}{411216096182401} & Unnamed Tributary to Elkhorn River at Q Street & $41^{\circ} 12^{\prime} 16^{\prime \prime}$ & $96^{\circ} 18^{\prime} 24^{\prime \prime}$ & $11 / 2 / 2016$ & 10.6 & Good & 10.1 & 11.1 & MEAS \\
\hline & & & & $8 / 2 / 2017$ & 0.63 & Good & 0.6 & 0.66 & MEAS \\
\hline \multirow[t]{2}{*}{412311096184201} & Rawhide Creek at N 252nd St near Arlington, Nebr. & $41^{\circ} 23^{\prime} 11^{\prime \prime}$ & $96^{\circ} 18^{\prime} 42^{\prime \prime}$ & $11 / 2 / 2016$ & 2.57 & Good & 2.44 & 2.7 & MEAS \\
\hline & & & & $8 / 2 / 2017$ & 0.81 & Good & 0.770 & 0.85 & MEAS \\
\hline \multirow[t]{2}{*}{412427096220301} & Rawhide Creek at 288th St nr Arlington, Nebr. & $41^{\circ} 24^{\prime} 27^{\prime \prime}$ & $96^{\circ} 22^{\prime} 03^{\prime \prime}$ & $11 / 2 / 2016$ & 1.76 & Good & 1.67 & 1.85 & MEAS \\
\hline & & & & $8 / 2 / 2017$ & 0.61 & Good & 0.580 & 0.64 & MEAS \\
\hline
\end{tabular}

aU.S. Geological Survey, 2018a.

${ }^{b}$ Lower and upper bounds of the discharge were based on the measurement quality rating and associated measurement error. 
To provide additional support to the water-level measurements, streamflow measurements were collected at selected locations of the Elkhorn River and major tributaries within the study area. Streamflow was measured along the Elkhorn River with an acoustic Doppler current profiler mounted to a catamaran tethered to a rope. The acoustic Doppler current profiler was towed across the stream channel at bridge crossings to measure the velocity profile of the river in accordance with the guidelines outlined in Mueller and others (2013). The streamflow of the tributaries was measured using a handheld acoustic Doppler velocimeter mounted to a wading rod in accordance with the guidelines and recommendations stated in Turnipseed and Sauer (2010) and from the USGS Office of Surface Water (U.S. Geological Survey, 2004). Streamflow measurements are given in table 2 and stored in the USGS NWIS (U.S. Geological Survey, 2018a).

The horizontal coordinates and elevations of groundwater levels, surface-water features, and streamflow measurements were used to create contour maps depicting water levels during low and high groundwater demand periods (figs. $3 \mathrm{~A}$ and $4 A$ ). Water-level contour maps were created within a geographic information system (GIS) environment using the plotted water-level elevations. Given the density of water-level elevation data and the vertical accuracy of the points, a 5-ft contour interval was chosen for the water-level maps. Groundwater level and surface-water elevations along with interpreted contours are available in Hobza and Strauch (2019). Streamflow measurements collected at multiple locations along the same stream indicated whether a stream was gaining or losing flow to the underlying aquifer along its reach (figs. $3 B$ and $4 B$ ). This information was used to assist in interpreting groundwater flow paths near streams.

\section{Aerial Thermal Infrared Imagery Methods}

Civilian use of TIR remote sensing began in 1968 when systems first were declassified by the military (Dugdale, 2016). Because of the coarse resolution of some of the early TIR systems, the primary research focus through the 1980s was mapping ocean (Anding and Kauth, 1970) and lake temperatures (Atwell and others, 1971; Dugdale, 2016; Rundquist and others, 1985). As more sophisticated TIR technology became available for civilian use, inexpensive, high-precision systems were developed enabling the use of TIR for mapping temperatures of river and stream systems (Dugdale, 2016). Researchers have applied TIR remote sensing to assess reachand watershed-scale stream-temperature patterns (Atwell and others, 1971; Torgersen and others, 2001), identify thermal refugia and habitat suitability for fish in streams (Dugdale and others, 2015; Torgersen and others, 1999; Vatland and others, 2015), identify zones of groundwater discharge into streams and estuaries (Banks and others, 1996; Liu and others, 2016; Loheide and Gorelick, 2006; Culbertson and others, 2014), and identify geologic controls on groundwater discharge (Hobza and Schepers, 2018). Dugdale (2016) published a summary of recent TIR-based studies since 2011 and documented an increase in published articles since 1995.

\section{Aerial Thermal Infrared Imagery Collection}

Advancements in aerial TIR remote-sensing technology have improved its utility for evaluating basin-wide groundwater discharge patterns because of the ability to cover entire stream systems with high-resolution imagery using fixed-wing aircraft. Groundwater discharge can be detected using thermal imaging technology because of the temperature difference between stable groundwater temperature and seasonally variable surface-water temperature. Temperature differences between groundwater and surface water are greatest during the summer and winter months. During these periods, it may be possible to identify and delineate areas of focused groundwater discharge in a steam by mapping stream surface temperatures with TIR (Banks and others, 1996). TIR sensors measure radiant energy from an object; in a stream, the temperature measured is representative of the top $0.0001 \mathrm{ft}$ of the stream (Torgersen and others, 2001). Groundwater discharge through streambeds within deeper parts of the stream channel may go undetected by TIR because of the extinction of the thermal signal at the stream surface caused by mixing.

For this study, aerial TIR imagery was collected with a FLIR midwave TIR camera, model SC8303 (FLIR, 2011) mounted to the belly of a Piper Saratoga aircraft. The FLIR SC8303 has a $0.3{ }^{\circ} \mathrm{C}$ sensitivity in the 3 - to 5-micron range and an absolute temperature accuracy of $2{ }^{\circ} \mathrm{C}$ across a range from -20 to $500{ }^{\circ} \mathrm{C}$ (FLIR, 2011). The FLIR SC8303 camera was controlled by custom software designed for airborne data acquisition. The camera was tightly integrated with a flight management system, a survey-grade airborne global positioning system (GPS), and an inertial measurement unit. Flight lines were designed before each flight to optimize data acquisition over the meandering streams. The contractor used the preplanned flight lines and the flight management system to ensure proper flying altitude and to provide coarse guidance. The GPS logged actual X, Y, and Z location data. The inertial measurement unit logged roll, pitch, and yaw orientation data for the camera.

Image spatial resolution is a function of lens focal length and the aircraft altitude during image collection. A higher altitude reduces spatial resolution because of the increased effective footprint, or field of view, of the thermal camera. An increased field of view requires less maneuvering and effort for the aircraft to adequately cover a meandering stream and adjacent low-lying areas, reducing the cost of data collection. The stream reach was flight planned to use a 1.6-ft ground sample distance to achieve the best spatial resolution while capturing the entire width of the stream in one pass.

The thermal imagery was collected when the temperature difference of groundwater compared to surface water would be at its maximum to optimize the detection of groundwater discharge. Aerial TIR was collected on December 15, 2017 , before the onset of ice when the stream temperature was 


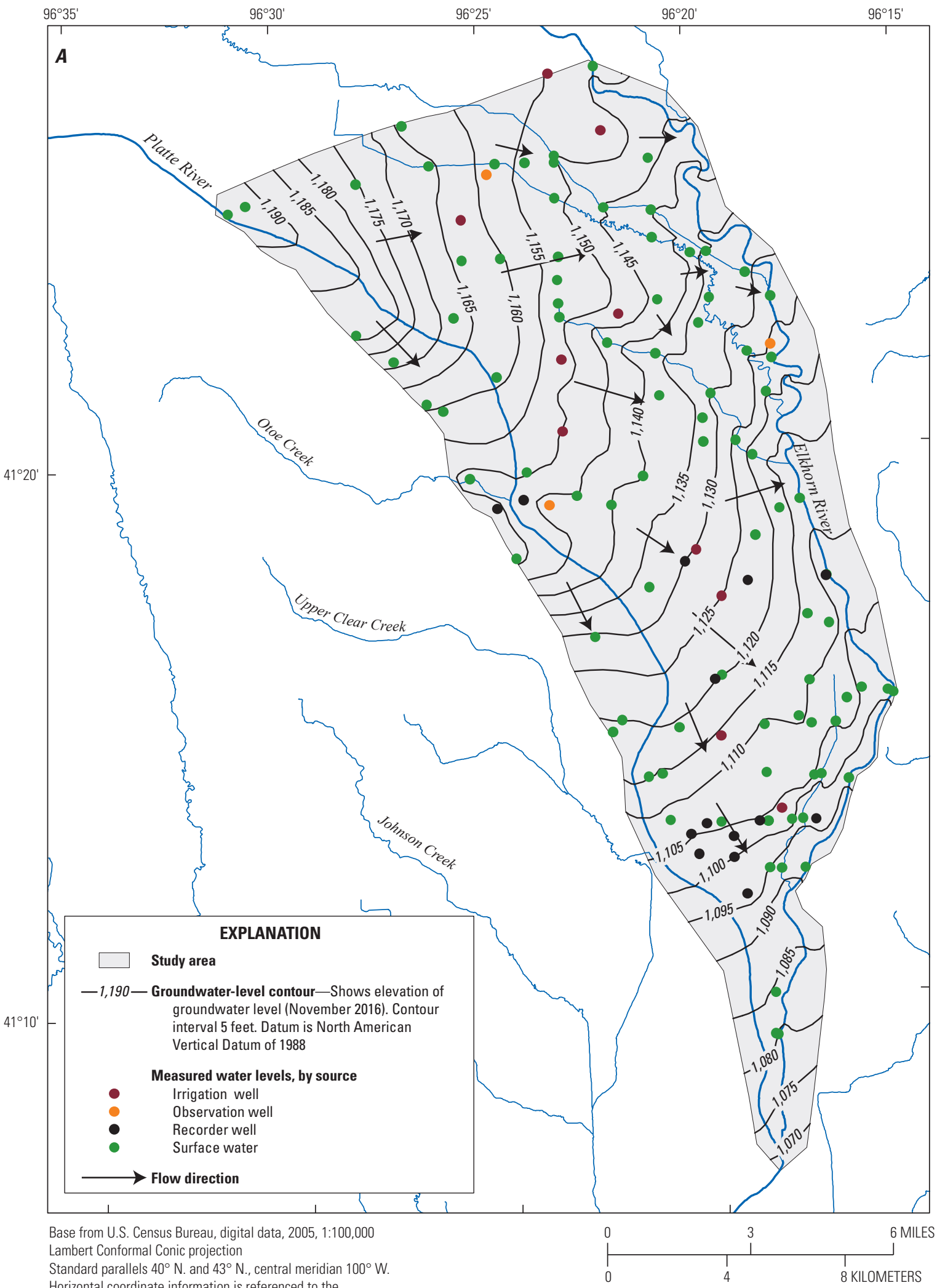

Horizontal coordinate information is referenced to the

North American Datum of 1983 (NAD 83)

Figure 3. Results from the low groundwater demand synoptic water-level and streamflow survey, November 2016. $A$, measured water-level locations from wells and surface-water features; and $B$, stream discharge and measurement locations within the study area. 


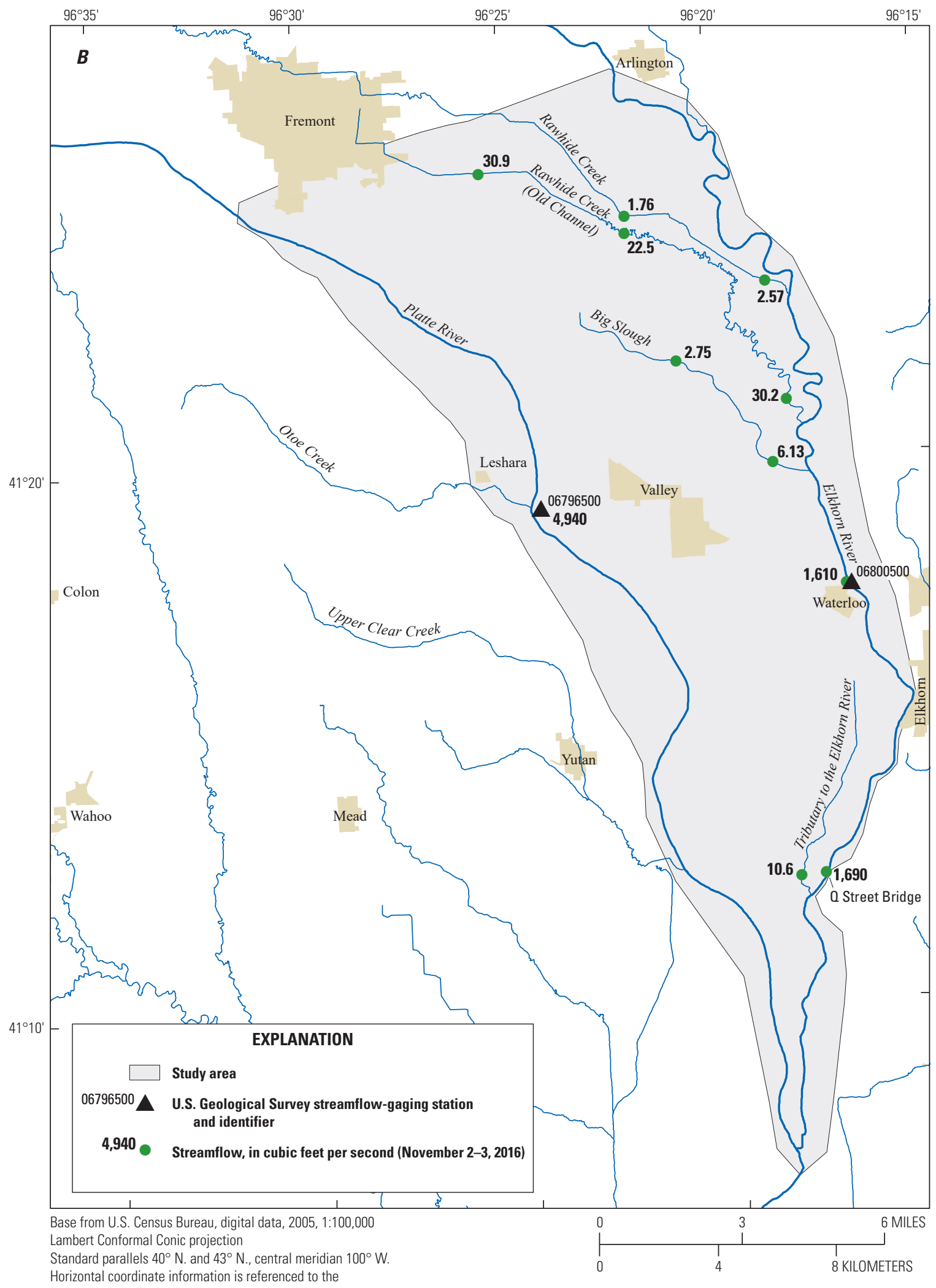

North American Datum of 1983 (NAD 83)

Figure 3. Results from the low groundwater demand synoptic water-level and streamflow survey, November 2016. $A$, measured water-level locations from wells and surface-water features; and $B$, stream discharge and measurement locations within the study area.-Continued 


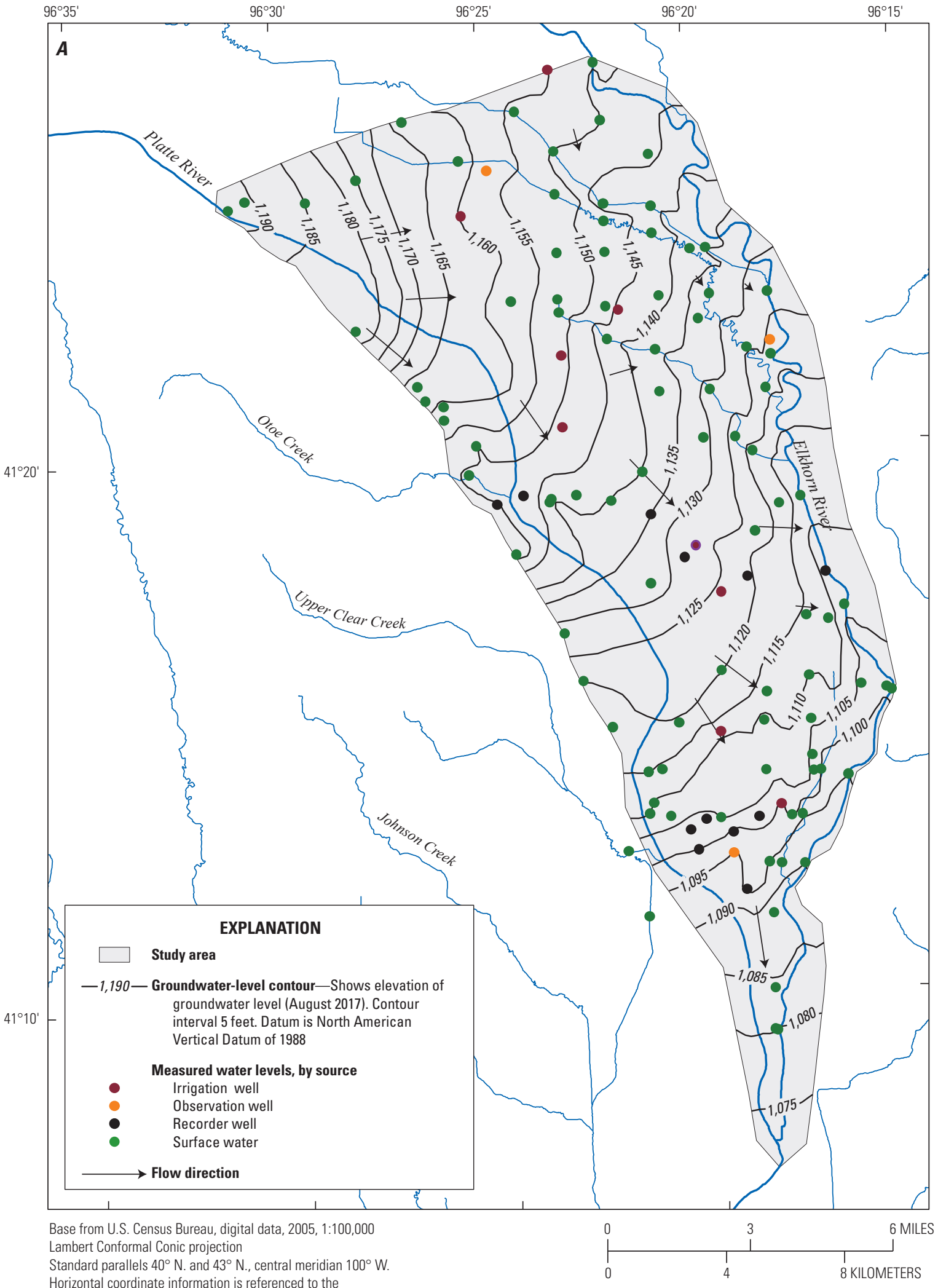

Horizontal coordinate information is referenced to the

North American Datum of 1983 (NAD 83)

Figure 4. Results from the high groundwater demand synoptic water-level and streamflow survey, August 2017. $A$, measured water-level locations from wells and surface-water features; and $B$, stream discharge and measurement locations within the study area. 


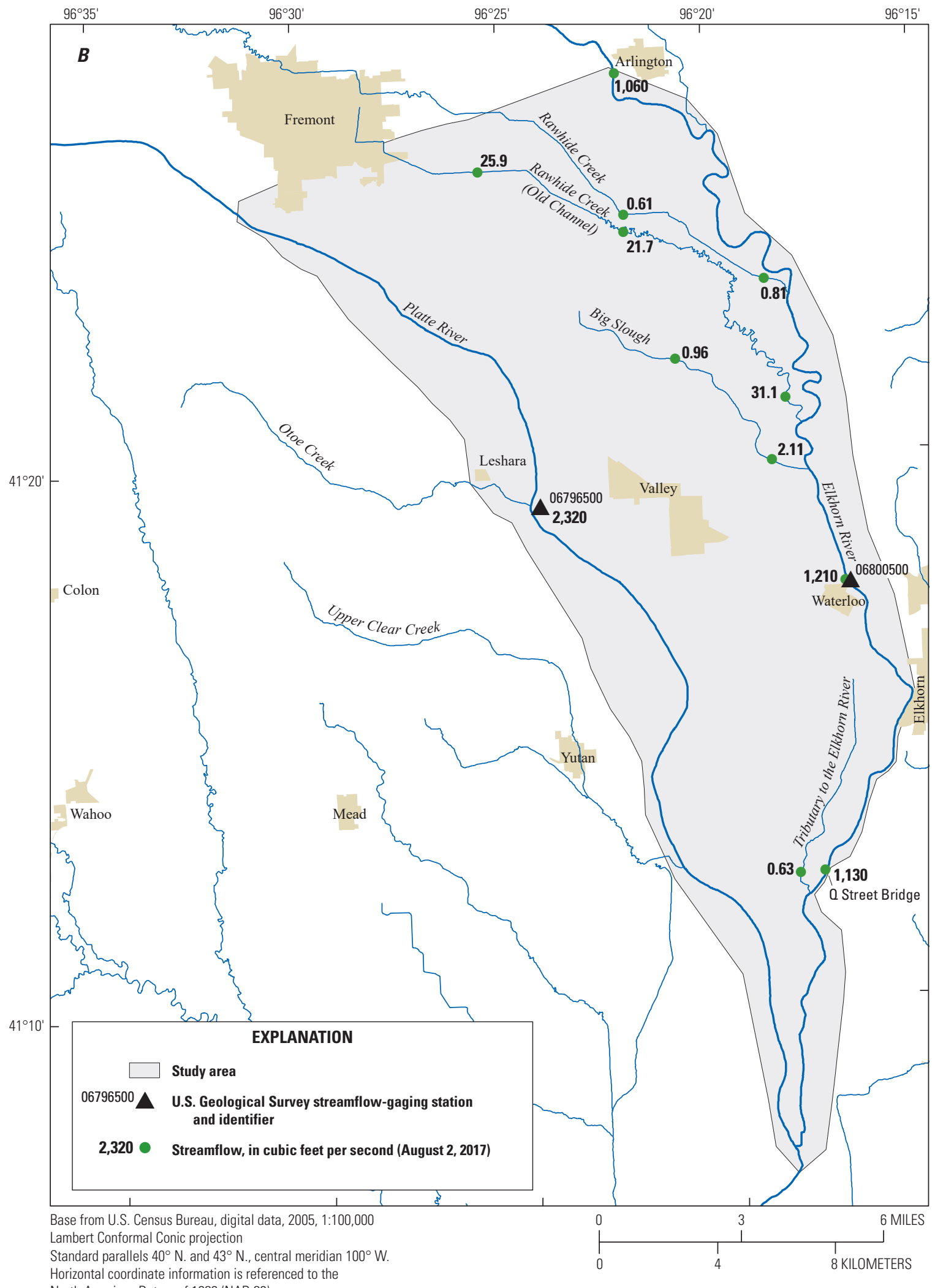

North American Datum of 1983 (NAD 83)

Figure 4. Results from the high groundwater demand synoptic water-level and streamflow survey, August 2017. $A$, measured water-level locations from wells and surface-water features; and $B$, stream discharge and measurement locations within the study area.-Continued 
near freezing (near $0^{\circ} \mathrm{C}$ ) and groundwater temperature was typically around $13{ }^{\circ} \mathrm{C}$ (U.S. Geological Survey, 2018a). This time of year also has the advantage of minimal obstructions of the stream surface from leaf and vegetative cover. Aerial TIR imagery was collected at nighttime to reduce the potential effects of solar reflection on the stream surface and eliminate thermal loading of the land and stream surface. As nighttime low temperatures pushed stream temperatures towards freezing, project personnel monitored the water temperature data collected at specific streamflow-gaging stations and weather forecasts. Caution was used to ensure that stream temperatures remained above freezing so that edges were not obscured by shore ice, which potentially could mask some focused groundwater discharge points.

Aerial TIR imagery was collected from 0.4 mi upstream from the Elkhorn River at Waterloo, Nebr., streamflow-gaging station (USGS station 06800500) to $1.8 \mathrm{mi}$ downstream from the Q Street Bridge (USGS station 06800800; fig. 5). This reach was identified during the low groundwater demand period synoptic water-level and streamflow survey as a reach where the Elkhorn River received a substantial amount of groundwater discharge.

\section{Image Calibration}

Before aerial TIR imagery was collected, self-logging temperature sensors (Onset, 2018) were deployed at two locations within the stream in addition to a thermistor deployed at the Elkhorn River at Waterloo, Nebr., streamflow-gaging station (U.S. Geological Survey station 06800500; fig. 5). The recorded water temperature data were used to ground truth and correct the aerial TIR data as described later in this section. Before deployment, the accuracy of all self-logging temperature sensors was verified by completing five-point temperature checks bracketing the expected range of environmental temperatures (Wagner and others, 2006). The temperature checks indicated that all self-logging temperature sensors were within plus or minus $( \pm) 0.2^{\circ} \mathrm{C}$ of the National Institute of Standards and Technology-measured temperature within a range from 0 to $30^{\circ} \mathrm{C}$. Self-logging temperature sensors were placed inside a small section of polyvinyl chloride pipe with holes drilled in it to allow water to flow past the temperature sensor. The pipe was attached to a t-post driven into the streambed. Side-byside temperature check measurements, as described in Wagner and others (2006), verified that the self-logging temperature sensors experienced minimal sensor drift through the duration of the deployment. Self-logging temperature sensor locations were determined with a handheld Magellan MobileMapper CX (Magellan, 2007) GPS unit. Site numbers are shown in figure 5 and recorded water temperature data were stored in NWIS (U.S. Geological Survey, 2018a).

A TIR camera does not measure the surface temperature directly; rather, the camera images the emitted infrared radiation from an object. Images of the emitted infrared radiation can be corrected to produce an accurate image of surface temperatures by estimating the emissivity of the object, atmospheric temperature, relative humidity, the distance between the object and the camera (altitude), and the reflected apparent temperature. The FLIR ResearchIR v4.0 (FLIR, 2014b) software package was used to compensate for these effects and produce images that represent the true temperature of the stream and adjacent areas. Reference temperatures (recorded stream temperatures) from the self-logging temperature sensors and thermistors at streamflow-gaging stations, collected at the time of the aerial TIR data collection, were used as validation points. The emissivity, which is the effectiveness of the target (water) surface to emit energy as thermal radiation, was estimated from published literature (FLIR, 2014a). Other variables such as atmospheric temperature, relative humidity, and atmospheric transmissivity were adjusted iteratively such that the best fit was achieved across all reference temperatures with corresponding points on the TIR imagery.

The root mean square error (RMSE) was calculated to assess the accuracy of the stream temperatures derived from corrected TIR imagery (Mikhail and others, 2001). The RMSE was quantified as the difference between the measured stream temperature and the corrected aerial TIR temperature using the following equation:

$$
R M S E=\sqrt{\frac{\sum(\text { Tmeas }- \text { Tcorr })^{2}}{n}}
$$

where

$$
\begin{gathered}
\text { RMSE } \\
\text { Tmeas the root mean square error, in }{ }^{\circ} \mathrm{C} ; \\
\text { is the temperature measured by the self- } \\
\text { logging temperature sensors or thermistors } \\
\text { at the streamflow-gaging stations; } \\
\text { is the temperature extracted from the } \\
\text { corrected TIR imagery; and } \\
\quad \text { is the number of locations where temperature }
\end{gathered}
$$

The RMSE was $0.48^{\circ} \mathrm{C}$ for the Elkhorn River based on three points (fig. 5). The largest difference between the TIR imagery and the in-stream temperature sensor was at the Elkhorn River at Waterloo, Nebr., streamflow-gaging station (06800500) where the TIR imagery was $0.8^{\circ} \mathrm{C}$ warmer than the temperature sensor.

\section{Orthorectification}

For this study, the contractor provided the aerial TIR imagery as georeferenced grids (also called rasters) for interpretation within a GIS environment. The TIR images were orthorectified (also termed georeferenced) using SimActive 3D Correlator software (SimActive Inc., 2016). SimActive 3D Correlator is a photogrammetric software package designed to orthorectify and mosaic aerial imagery. The temperature-corrected TIR images, USGS 10-meter digital elevation model (Nebraska Department of Natural Resources and U.S. Geological Survey, 1998), and exterior camera 


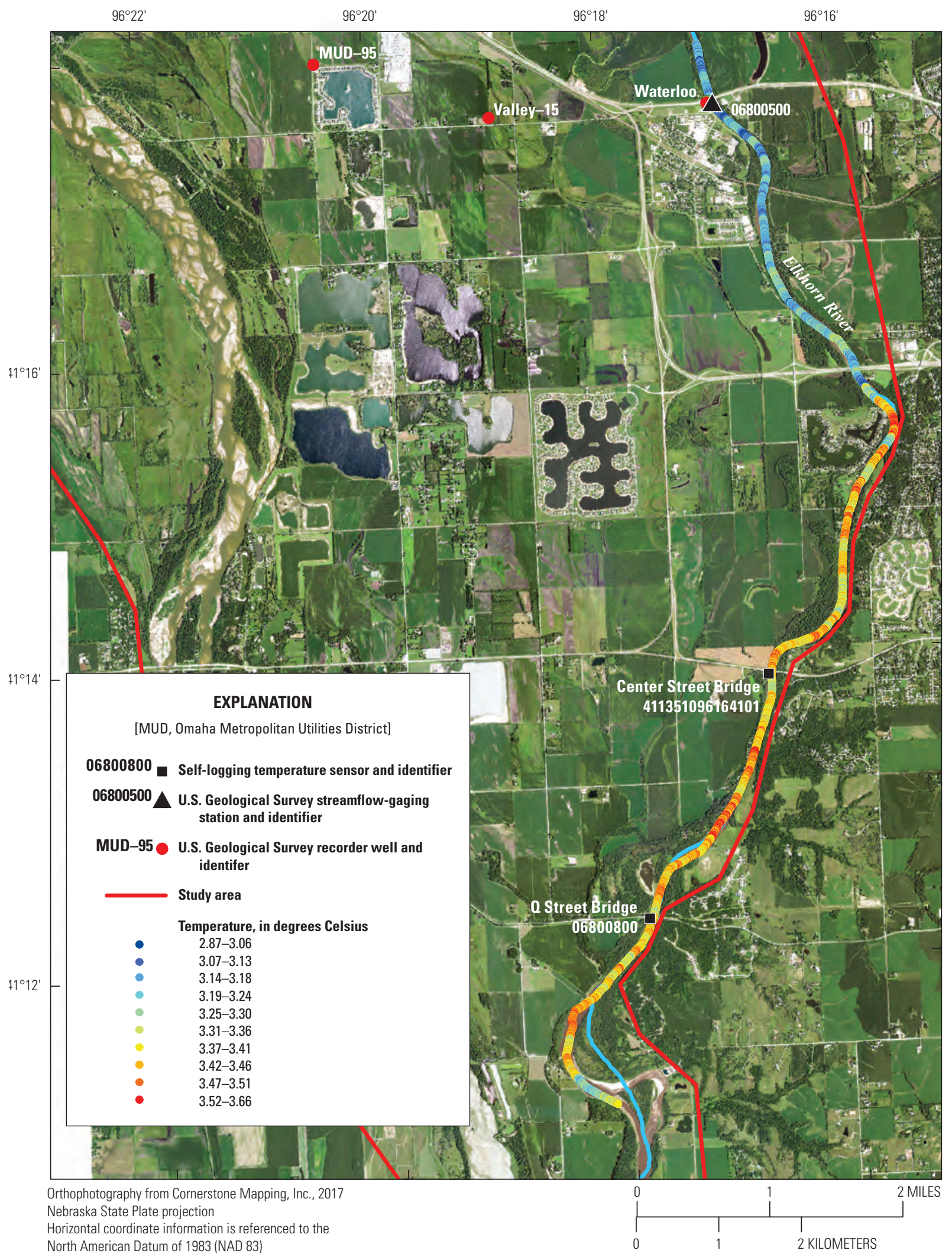

Figure 5. Map of reach where aerial thermal infrared (TIR) imagery was collected, self-logging temperature locations, and surface temperature of the Elkhorn River determined with aerial TIR, December 15, 2017. 
orientation data logged by the GPS/inertial measurement unit system were used as data inputs.

Reference imagery was used to provide photographs of identifiable ground control points to help enhance the aerial triangulation solution. Four-band orthoimages previously collected by the contractor (Cornerstone Mapping, unpub. data, 2017) for other mapping purposes were used as reference images. This set of reference images was collected with a 2 -ft ground sample distance. The contractor-supplied imagery was needed to add temporally valid, visual context with high spatial resolution, which aided thermal image interpretation. The horizontal accuracy of the orthorectified TIR imagery was within $1.3 \mathrm{ft}$ of the reference imagery (Hobza and Strauch, 2019). Orthorectified TIR imagery are available in Hobza and Strauch (2019).

\section{Thermal Infrared Imagery Analysis}

Georeferenced TIR imagery was interpreted within a GIS environment by creating a downstream temperature profile where stream surface temperatures are extracted every $6.6 \mathrm{ft}$ along a digitized stream centerline. The extracted point temperatures were plotted against distance upstream or downstream from the Elkhorn River at Waterloo, Nebr., streamflowgaging station (06800500). Because aerial TIR imagery was collected before the onset of ice, warmer stream temperatures would be the result of an increase in the proportion of groundwater discharge relative to total streamflow. The downstream temperature profiles included parts of the stream that were totally or partially obstructed by bridges, which had a different temperature than the stream surface. Spikes of extracted point temperature data at bridge crossings were removed to isolate the water temperature data.

\section{Temperature-Based Streambed Flux Estimates}

Groundwater/surface-water exchange, or streambed flux rates, were estimated using heat as a tracer. The effectiveness of using heat as a tracer in groundwater and surface-water interaction studies has been well established. Heat tracer techniques have been applied successfully to determine streambed hydraulic conductivity (Essaid and others, 2007; Eddy-Miller and others, 2009; Zamora, 2008), assess diurnal and annual variability in groundwater/surface-water exchanges (Cox and others, 2007), determine groundwater recharge from ephemeral streams and canals (Constantz and others, 2002; Hobza and Andersen, 2010; Naranjo and Smith, 2016), and understand streambed thermal refugia (Briggs and others, 2013). The practicality of using heat as a tracer has improved substantially in recent years because of improvements in data-collection equipment and computational capabilities (Stonestrom and Constantz, 2003). For more detail on the use of this technique in studies of groundwater and surface-water interaction and groundwater transport, refer to Stonestrom and Constantz (2003), Andersen (2006), Blasch and others (2007), Constantz and others (2002), and Constantz and others (2008).
Stallman (1965) developed a one-dimensional analytical solution to estimate flux based on sinusoidal temperature signals, which are the result of daily heating and cooling of streams. Under steady streamflow conditions, the daily minimum temperature in a stream is typically just prior to sunrise and the daily maximum is typically before sunset. This daily pattern results in diurnal temperature cycles and gives stream temperature time series data a characteristic sinusoidal shape and diurnal amplitude. As heat is transferred from the stream water to the underlying sediments through conduction and (or) advection, the daily minimum temperature of streambed sediments is just prior to sunrise and the daily maximum is before sunset, with a dampened diurnal amplitude. A time lag exists between the time when the daily minimum and maximum temperatures happen in the stream compared to the streambed, resulting in a phase shift in the sinusoidal temperature signal. In addition to the phase shift, the diurnal amplitude decreases as heat is transferred to deeper parts of the streambed (Briggs and others, 2014). In cases of groundwater recharge, where water moves from the stream through the streambed, heat is transferred by advection and conduction and the diurnal temperature signals can reach to depths of as much as $1.6 \mathrm{ft}$ (Irvine and others, 2016). Conversely, in cases of groundwater discharge where water moves through the streambed into the stream, heat is transferred by only conduction. The upward movement of groundwater can limit the depth at which the diurnal temperature signal can be measured to the upper $0.7 \mathrm{ft}$ of streambed (Briggs and others, 2014).

In recent years, the analytical solution produced by Stallman (1965) has been reworked to estimate flux based on the amplitude ratio (Hatch and others, 2006) and the phase shift (Keery and others, 2007) between two streambed temperature time series records. Other researchers have developed solutions that use amplitude ratio and phase shift simultaneously to estimate flux (McCallum and others, 2012; Luce and others, 2013). These approaches rely on the estimation of thermal properties such as thermal conductivity of the saturated sediment and volumetric heat capacity of the water and sediment (Irvine and others, 2016). Constantz and others (2008) reported that thermal properties have a much smaller range than hydraulic properties such as hydraulic conductivity; however, uncertainties in thermal properties can lead to greater uncertainty in the calculated flux, particularly in cases of groundwater discharge (Briggs and others, 2014).

The analytical model Vertical Fluid Heat Transfer Solver (VFLUX) was initially developed by Gordon and others (2012) in the MATLAB ${ }^{\circledR}$ (MathWorks, 2018) environment to estimate vertical water flux in porous media using temperature time series data. The VFLUX analytical model integrates data management, signal processing, fluid flux modeling, and analysis routines (Irvine and others, 2015). VFLUX includes analytical solutions from Hatch and others (2006) and Keery and others (2007). Irvine and others (2015) improved the original analytical model to create VFLUX2, which includes analytical solutions from McCallum and others (2012) and Luce and others (2013). 
Temperature time series data from multiple depths below the streambed surface are the primary data inputs for the VFLUX2 analytical model. The VFLUX2 analytical model assumes vertical, one-dimensional flow within the streambed and calculates the vertical water flux at the midpoint depth between a pair of sensors. Irvine and others (2015) stated that analytical solutions that rely on the amplitude ratio (Hatch and others, 2006) perform better when water flux is variable with time, which is often the case for many natural streams. Previous researchers have stated that multidimensional flow was a greater source of error compared to imperfect or nonsinusoidal temperature signals (Lautz, 2010).

\section{Location Selection and Data Collection}

Streambed flux was estimated at two locations along the Elkhorn River within the study area (fig. 1). The first location, referred to as "Waterloo SBF," was approximately $1 \mathrm{mi}$ south of the Elkhorn River at Waterloo, Nebr., streamflowgaging station (06800500) along the southeastern edge of the city of Waterloo, Nebr. (fig. 1). The second location, referred to as "Elkhorn Crossing SBF," was approximately $6 \mathrm{mi}$ north of the Elkhorn River at Waterloo, Nebr., streamflowgaging station (06800500) and $1 \mathrm{mi}$ north of the confluence of the Elkhorn River with Rawhide Creek (Old Channel) on PMRNRD-owned property (fig. 1). Based on geologic cross sections near the Elkhorn River (Carney and others, 2015; Korus and others, 2012), the alluvial aquifer at the Elkhorn Crossing SBF location is thinner compared to the Waterloo SBF location. Locations were chosen in areas that provided convenient access at higher-than-normal streamflow and were used to assess the potential effect of alluvial aquifer thickness and permeability on streambed flux rates. Instrumentation was generally grouped along the right bank of the Elkhorn River to characterize and estimate streambed flux associated with the southeastward movement of groundwater within the study area and because higher-than-normal streamflows made accessing other parts of the stream channel difficult.

The use of heat as a tracer to estimate streambed flux requires monitoring the diel (24-hour) amplitude of temperature at multiple depths beneath the streambed. Continuous streambed temperature data were collected at multiple depths with vertical temperature arrays. The basic design of the vertical temperature arrays included a series of self-logging temperature sensors placed at specific depths within a solid rod driven into the streambed. Three configurations of vertical temperature arrays were used to estimate streambed flux along the Elkhorn River.

Two configurations of self-logging vertical temperature arrays used an Alpha Mach TROD, which was a ruggedized plastic probe that housed self-logging temperature sensors at specified depths (Naranjo and Turcotte, 2015). The TROD was developed by Alpha Mach Inc. and has been used by the USGS to estimate seepage in unlined irrigation canals (Naranjo and Smith, 2016). The TRODs housed self-logging type-L iButton Thermochron temperature sensors (Alpha Mach Inc.,
2018) using two different sensor depth configurations. The first configuration used five self-logging type-L iButton temperature sensors placed at $0,0.16,0.49,1.15$, and $3.28 \mathrm{ft}$ below the streambed surface (table 3 ) and the second configuration used six type-L iButton Thermochron temperature sensors (Alpha Mach Inc., 2018) placed at approximately $0.16,0.33,0.49$, $0.82,1.31$, and $2.13 \mathrm{ft}$ below the streambed surface (table 3 ). The manufacturer's specification for precision of the iButton temperature sensor was $\pm 0.5^{\circ} \mathrm{C}$ and the resolution was $0.063^{\circ} \mathrm{C}$ (Alpha Mach Inc., 2018).

The third configuration of self-logging vertical temperature arrays used a design like that described in Eddy-Miller and others (2009). This configuration of vertical temperature arrays used five Onset ${ }^{\circledR}$ Tidbit v2 Temperature Loggers (Onset, 2018) placed within a 1.25-in. diameter galvanized, continuously screened sand point. The self-logging temperature sensors were placed at $0.33,0.66,0.82,1.31$, and $1.64 \mathrm{ft}$ from the streambed surface (table 3 ). The manufacturer specified precision for the self-logging temperature sensors was $\pm 0.2^{\circ} \mathrm{C}$ and the resolution was $0.02{ }^{\circ} \mathrm{C}$ (Onset, 2018).

Before installation into the streambed, the accuracy of all self-logging temperature sensors was verified by completing five-point temperature checks bracketing the expected range of environmental temperatures (Wagner and others, 2006). The temperature checks indicated that all self-logging temperature sensors were generally within $\pm 0.2^{\circ} \mathrm{C}$ of the National Institute of Standards and Technology-certified thermometer measured temperature within a range from 0 to $30^{\circ} \mathrm{C}$.

Self-logging temperature sensors within each vertical temperature array were synchronized with a field laptop computer and set to log temperature every 15 minutes. Vertical temperature arrays were driven into the sandy streambed using a sledgehammer. Specific locations were chosen such that they remained submerged at lower flows but would still be accessible during moderate runoff events. Vertical temperature arrays were surveyed with a Global Navigation Satellite Systems rover receiver using an RTN (U.S. Geological Survey, 2018b) where the rover receiver receives real-time position corrections from a central server to a mobile Wi-Fi hotspot linked to the rover receiver. Field procedures ensured the survey achieved Level-IV accuracy (Rydlund and Densmore, 2012). A subscription for an RTN service (Seiler Geospatial Division, 2018) was activated for the Trimble R8 GPS (Trimble Navigation Limited, 2009) or a Topcon HiPer SR (Topcon Positioning Systems, Inc., 2018) rover and handheld. The location, configuration, and deployment period of each vertical sensor array is given in table 3 .

Streambed temperature data were collected in late summer of 2017 when the difference between warmer surface water and groundwater would be greatest. Temperature data were collected at the Waterloo SBF location from July 13 to August 16, 2017, and at the Elkhorn Crossing SBF location from August 30 to September 21, 2017. No vertical sensor arrays were deployed during a 2-week window in late August when local precipitation and runoff events increased the stage of the Elkhorn River at Waterloo, Nebr., streamflow-gaging 
Table 3. Location, configuration, and deployment period of vertical temperature arrays.

[Deployment dates, date range which the sensor was collecting streambed temperature data; Easting is referenced to Nebraska State Plane, in feet; Northing is referenced to Nebraska State Plane, in feet; sensor depths, depth in feet below the streambed surface where temperature sensors were installed; TROD refers to Alpha Mach (Alpha Mach, 2018) temperature rod; SP is where self-logging Onset temperature sensors (Onset, 2018) were placed inside a sand point; bold depths indicate sensor was used in flux estimates]

\begin{tabular}{|c|c|c|c|c|c|c|c|c|c|c|c|}
\hline Site number & Station name & $\begin{array}{l}\text { Vertical } \\
\text { tempertaure } \\
\text { array type }\end{array}$ & $\begin{array}{l}\text { Field } \\
\text { name }\end{array}$ & $\begin{array}{c}\text { Sensor } \\
\text { deployment } \\
\text { date, } \\
\text { start and } \\
\text { end }\end{array}$ & $\begin{array}{c}\text { Flux } \\
\text { estimate } \\
\text { start, } \\
\text { date and } \\
\text { time }\end{array}$ & $\begin{array}{c}\text { Flux } \\
\text { estimate } \\
\text { end, } \\
\text { date and } \\
\text { time }\end{array}$ & $\begin{array}{c}\text { Latitude, } \\
\text { in degrees, } \\
\text { minutes, seconds }\end{array}$ & $\begin{array}{c}\text { Longitude, } \\
\text { in degrees, } \\
\text { minutes, seconds }\end{array}$ & Easting & Northing & $\begin{array}{l}\text { Sensor } \\
\text { depths, } \\
\text { in feet }\end{array}$ \\
\hline 411659096163601 & 15N 10E10DABC1 & TROD & Q8 & $\begin{array}{c}7 / 13 / 17- \\
8 / 10 / 17\end{array}$ & $\begin{array}{c}7 / 13 / 17 \\
15: 30\end{array}$ & $\begin{array}{c}8 / 10 / 17 \\
10: 45\end{array}$ & $41^{\circ} 16^{\prime} 59.39103^{\prime \prime} \mathrm{N}$ & $96^{\circ} 16^{\prime} 35.66430^{\prime \prime} \mathrm{W}$ & 2663138.1 & 550135.2 & $\begin{array}{l}\mathbf{0 . 1 6}, \mathbf{0 . 3 3}, \\
\mathbf{0 . 4 9}, 0.82, \\
1.31,2.13\end{array}$ \\
\hline 411700096163501 & $15 \mathrm{~N} 10 \mathrm{E} 10 \mathrm{DABC} 2$ & TROD & Q11 & $\begin{array}{c}7 / 13 / 17- \\
8 / 10 / 17\end{array}$ & $\begin{array}{c}7 / 20 / 17 \\
16: 30\end{array}$ & $\begin{array}{c}8 / 10 / 17 \\
11: 30\end{array}$ & $41^{\circ} 17^{\prime} 00.59717^{\prime \prime} \mathrm{N}$ & $96^{\circ} 16^{\prime} 35.34357^{\prime \prime} \mathrm{W}$ & 2663157.3 & 550258.2 & $\begin{array}{l}\mathbf{0 . 1 6}, \mathbf{0 . 3 3}, \\
\mathbf{0 . 4 9}, 0.82, \\
1.31,2.13\end{array}$ \\
\hline 411654096163701 & $15 \mathrm{~N}$ 10E10DACB1 & TROD & Q5 & $\begin{array}{c}7 / 13 / 17- \\
8 / 16 / 17\end{array}$ & $\begin{array}{c}7 / 13 / 17 \\
16: 15\end{array}$ & $\begin{array}{c}8 / 15 / 17 \\
17: 00\end{array}$ & $41^{\circ} 16^{\prime} 54.55579^{\prime \prime} \mathrm{N}$ & $96^{\circ} 16^{\prime} 37.76451^{\prime \prime} \mathrm{W}$ & 2662999.0 & 549639.6 & $\begin{array}{c}\mathbf{0 , 0 . 1 6}, \\
\mathbf{0 . 4 9}, 1.15 \\
3.28\end{array}$ \\
\hline 411659096163503 & $15 \mathrm{~N}$ 10E10DABC8 & TROD & 2844 & $\begin{array}{c}8 / 11 / 17- \\
8 / 16 / 17\end{array}$ & $\begin{array}{c}8 / 11 / 17 \\
13: 58\end{array}$ & $\begin{array}{c}8 / 16 / 17 \\
16: 28\end{array}$ & $41^{\circ} 16^{\prime} 59.831^{\prime \prime} \mathrm{N}$ & $96^{\circ} 16^{\prime} 35.804^{\prime \prime} \mathrm{W}$ & 2663125.5 & 550179.3 & $\begin{array}{l}\mathbf{0 . 1 6}, \mathbf{0 . 3 3}, \\
\mathbf{0 . 4 9}, 0.82, \\
1.31,2.13\end{array}$ \\
\hline 411700096163502 & 15N 10E10DABC9 & TROD & 3281 & $\begin{array}{c}8 / 11 / 17- \\
8 / 16 / 17\end{array}$ & $\begin{array}{c}8 / 11 / 17 \\
13: 57\end{array}$ & $\begin{array}{c}8 / 16 / 17 \\
16: 12\end{array}$ & $41^{\circ} 17^{\prime} 00.129^{\prime \prime} \mathrm{N}$ & $96^{\circ} 16^{\prime} 35.128^{\prime \prime} \mathrm{W}$ & 2663171.7 & 550211.4 & $\begin{array}{l}\mathbf{0 . 1 6}, \mathbf{0 . 3 3}, \\
\mathbf{0 . 4 9}, 0.82, \\
1.31,2.13\end{array}$ \\
\hline 411700096163401 & 15N 10E10DABC5 & TROD & 3674 & $\begin{array}{c}8 / 11 / 17- \\
8 / 16 / 17\end{array}$ & $\begin{array}{c}8 / 11 / 17 \\
13: 39\end{array}$ & $\begin{array}{c}8 / 16 / 17 \\
16: 24\end{array}$ & $41^{\circ} 17^{\prime} 00.6374^{\prime \prime N}$ & $96^{\circ} 16^{\prime} 34.4583^{\prime \prime} \mathrm{W}$ & 2663224.6 & 550265.2 & $\begin{array}{c}\mathbf{0 , 0 . 1 6}, \\
\mathbf{0 . 4 9 ,} 1.15, \\
3.28\end{array}$ \\
\hline 411700096163402 & 15N 10E10DABC6 & TROD & 3731 & $\begin{array}{c}8 / 11 / 17- \\
8 / 16 / 17\end{array}$ & $\begin{array}{c}8 / 11 / 17 \\
13: 37\end{array}$ & $\begin{array}{c}8 / 16 / 17 \\
16: 37\end{array}$ & $41^{\circ} 17^{\prime} 00.6084^{\prime \prime} \mathrm{N}$ & $96^{\circ} 16^{\prime} 34.2960^{\prime \prime} \mathrm{W}$ & 2663237.1 & 550262.8 & $\begin{array}{c}\mathbf{0 , 0 . 1 6}, \\
\mathbf{0 . 4 9 ,} 1.15 \\
3.28\end{array}$ \\
\hline 411659096163501 & $15 \mathrm{~N}$ 10E10DABC7 & TROD & 3648 & $\begin{array}{l}8 / 8 / 17- \\
8 / 16 / 17\end{array}$ & $\begin{array}{c}8 / 8 / 17 \\
18: 23\end{array}$ & $\begin{array}{c}8 / 16 / 17 \\
16: 23\end{array}$ & $41^{\circ} 16^{\prime} 59.8270^{\prime \prime} \mathrm{N}$ & $96^{\circ} 16^{\prime} 34.7687^{\prime \prime} \mathrm{W}$ & 2663204.5 & 550182.2 & $\begin{array}{c}0, \mathbf{0 . 1 6}, \\
\mathbf{0 . 4 9}, 1.15 \\
3.28\end{array}$ \\
\hline 411658096163501 & $15 \mathrm{~N}$ 10E10DABC4 & SP & Q7 & $\begin{array}{c}7 / 12 / 17- \\
8 / 10 / 17\end{array}$ & $\begin{array}{c}7 / 12 / 17 \\
16: 00\end{array}$ & $\begin{array}{c}8 / 10 / 17 \\
10: 00\end{array}$ & $41^{\circ} 16^{\prime} 58.91320^{\prime \prime} \mathrm{N}$ & $96^{\circ} 16^{\prime} 35.80666^{\prime \prime} \mathrm{W}$ & 2663129.3 & 550086.5 & $\begin{array}{c}\mathbf{0 . 3 3}, \mathbf{0 . 6 6} \\
\mathbf{0 . 8 2}, 1.31 \\
1.64\end{array}$ \\
\hline 412136096180001 & 16N 10E16ACBA1 & TROD & E1 & $\begin{array}{c}8 / 30 / 17- \\
9 / 21 / 17\end{array}$ & $\begin{array}{c}8 / 30 / 17 \\
12: 15\end{array}$ & $\begin{array}{c}9 / 21 / 17 \\
9: 30\end{array}$ & $41^{\circ} 21^{\prime} 36.8022^{\prime \prime} \mathrm{N}$ & $96^{\circ} 18^{\prime} 0.3924^{\prime \prime} \mathrm{W}$ & 2655476.8 & 577900.5 & $\begin{array}{l}\mathbf{0 . 1 6}, \mathbf{0 . 3 3}, \\
\mathbf{0 . 4 9}, 0.82, \\
1.31,2.13\end{array}$ \\
\hline
\end{tabular}


Table 3. Location, configuration, an deployment period of vertical temperature arrays. - Continued

[Deployment dates, date range which the sensor was collecting streambed temperature data; Easting is referenced to Nebraska State Plane, in feet; Northing is referenced to Nebraska State Plane, in feet; sensor depths, depth in feet below the streambed surface where temperature sensors were installed; TROD refers to Alpha Mach (Alpha Mach, 2018) temperature rod; SP is where self-logging Onset temperature sensors (Onset, 2018) were placed inside a sand point; bold depths indicate sensor was used in flux estimates]

\begin{tabular}{|c|c|c|c|c|c|c|c|c|c|c|c|}
\hline Site number & Station name & $\begin{array}{l}\text { Vertical } \\
\text { tempertaure } \\
\text { array type }\end{array}$ & $\begin{array}{l}\text { Field } \\
\text { name }\end{array}$ & $\begin{array}{l}\text { Sensor } \\
\text { deployment } \\
\text { date, } \\
\text { start and } \\
\text { end }\end{array}$ & $\begin{array}{c}\text { Flux } \\
\text { estimate } \\
\text { start, } \\
\text { date and } \\
\text { time }\end{array}$ & $\begin{array}{c}\text { Flux } \\
\text { estimate } \\
\text { end, } \\
\text { date and } \\
\text { time }\end{array}$ & $\begin{array}{c}\text { Latitude, } \\
\text { in degrees, } \\
\text { minutes, seconds }\end{array}$ & $\begin{array}{c}\text { Longitude, } \\
\text { in degrees, } \\
\text { minutes, seconds }\end{array}$ & Easting & Northing & $\begin{array}{l}\text { Sensor } \\
\text { depths, } \\
\text { in feet }\end{array}$ \\
\hline 412136096175901 & 16N 10E16ACBA2 & TROD & E2 & $\begin{array}{l}8 / 30 / 17- \\
10 / 12 / 17\end{array}$ & $\begin{array}{c}8 / 30 / 17 \\
12: 30\end{array}$ & $\begin{array}{c}9 / 15 / 17 \\
13: 00\end{array}$ & $41^{\circ} 21^{\prime} 36.993^{\prime \prime} \mathrm{N}$ & $96^{\circ} 17^{\prime} 59.5608^{\prime \prime} \mathrm{W}$ & 2655539.2 & 577922.3 & $\begin{array}{c}\mathbf{0 , 0 . 1 6}, \\
0.49,1.15 \\
3.28\end{array}$ \\
\hline 412136096175902 & 16N 10E16ACBA3 & TROD & E3 & $\begin{array}{c}8 / 30 / 17- \\
9 / 21 / 17\end{array}$ & $\begin{array}{c}8 / 30 / 17 \\
12: 30\end{array}$ & $\begin{array}{c}9 / 21 / 17 \\
10: 00\end{array}$ & $41^{\circ} 21^{\prime} 36.9138^{\prime \prime} \mathrm{N}$ & $96^{\circ} 17^{\prime} 59.535^{\prime \prime} \mathrm{W}$ & 2655541.3 & 577914.4 & $\begin{array}{c}\mathbf{0 , 0 . 1 6} \\
\mathbf{0 . 4 9 , 1 . 1 5} \\
3.28\end{array}$ \\
\hline 412136096175903 & $16 \mathrm{~N}$ 10E16ACBA4 & TROD & E4 & $\begin{array}{c}8 / 30 / 17- \\
9 / 21 / 17\end{array}$ & $\begin{array}{c}8 / 30 / 17 \\
12: 45\end{array}$ & $\begin{array}{c}9 / 21 / 17 \\
13: 45\end{array}$ & $41^{\circ} 21^{\prime} 36.7776^{\prime \prime} \mathrm{N}$ & $96^{\circ} 17^{\prime} 59.4996^{\prime \prime} \mathrm{W}$ & 2655544.7 & 577900.9 & $\begin{array}{c}\mathbf{0 , 0 . 1 6} \\
\mathbf{0 . 4 9 ,}, 1.15 \\
3.28\end{array}$ \\
\hline 412136096175904 & 16N 10E16ACBA5 & TROD & E5 & $\begin{array}{l}8 / 30 / 17- \\
10 / 12 / 17\end{array}$ & $\begin{array}{c}8 / 30 / 17 \\
12: 45\end{array}$ & $\begin{array}{c}9 / 21 / 17 \\
9: 30\end{array}$ & $41^{\circ} 21^{\prime} 36.6006^{\prime \prime} \mathrm{N}$ & $96^{\circ} 17^{\prime} 59.4636^{\prime \prime} \mathrm{W}$ & 2655548.4 & 577883.3 & $\begin{array}{c}\mathbf{0 , 0 . 1 6} \\
\mathbf{0 . 4 9 , 1 . 1 5} \\
3.28\end{array}$ \\
\hline 412137096175801 & 16N 10E16ACBA6 & TROD & E6 & $\begin{array}{c}8 / 30 / 17- \\
9 / 21 / 17\end{array}$ & $\begin{array}{c}8 / 30 / 17 \\
12: 45\end{array}$ & $\begin{array}{c}9 / 15 / 17 \\
13: 00\end{array}$ & $41^{\circ} 21^{\prime} 37.0254^{\prime \prime} \mathrm{N}$ & $96^{\circ} 17^{\prime} 58.761^{\prime \prime} \mathrm{W}$ & 2655599.9 & 577928.5 & $\begin{array}{l}\mathbf{0 . 1 6}, \mathbf{0 . 3 3} \\
\mathbf{0 . 4 9}, 0.82 \\
1.31,2.13\end{array}$ \\
\hline
\end{tabular}


station (06800500) by $4 \mathrm{ft}$ (U.S. Geological Survey, 2018a), making access to the streambed unsafe. All temperature timeseries data are available from the NWIS database (U.S. Geological Survey, 2018a).

\section{Streambed Flux Calculations and Analysis}

This section of the report describes the streambed flux calculation approach and includes a discussion of temperature data processing, assumptions, and data display and interpretation. After streambed temperature data were downloaded from the field, data were formatted so each sample time included measured data from each sensor depth. Formatted temperature data were imported into the MATLAB environment for further processing. Several factors or variables were specified prior to running the VFLUX2 script, including a resampling factor. The default resampling factor was chosen to allow VFLUX2 to calculate the appropriate factor such that the time series was reduced to approximately 12 samples per day. The resampled temperature time series still produces the characteristic diurnal sinusoidal curve while removing redundant and anomalous data points (Irvine and others, 2015; Gordon and others, 2012). Thermal and physical parameters such as porosity, thermal conductivity, and volumetric heat capacity of the streambed sediment were estimated based on review of published material (table 4; given in metric units). The values given in table 4 were general estimates for the study area and assumed for each vertical temperature array location because it was assumed that the properties would not vary, in part because of their proximity to one another.

Table 4. Selected hydraulic and thermal parameters used in VFLUX2 calculations.

[VFLUX2, Vertical Fluid Heat Transfer Solver 2]

\begin{tabular}{lll}
\hline \multicolumn{1}{c}{ Parameter } & Value & \multicolumn{1}{c}{ Units } \\
\hline Porosity & $0.300^{\mathrm{a}}$ & Dimensionless \\
\hline Dispersivity & $0.001^{\mathrm{b}}$ & $\begin{array}{l}\text { Meter } \\
\text { Calorie/(second centimeter } \\
\text { degree Celsius) }\end{array}$ \\
$\begin{array}{l}\text { Thermal conductivity } \\
\begin{array}{c}\text { Volumetric heat } \\
\text { capacity } \\
\text { (sediment) }\end{array}\end{array}$ & $0.005^{\mathrm{c}}$ & $\begin{array}{c}\text { Calorie/(cubic centimeter } \\
\text { degree Celsius) }\end{array}$ \\
$\begin{array}{c}\text { Volumetric heat } \\
\text { capacity (water) }\end{array}$ & $1^{\mathrm{e}}$ & $\begin{array}{c}\text { Calorie/(cubic centimeter } \\
\text { degree Celsius) }\end{array}$ \\
\hline
\end{tabular}

${ }^{\mathrm{a}}$ Freeze and Cherry, 1979.

bSchulze-Makuch, 2005.

'Eppelbaum and others, 2014.

dStonestrom and Constantz, 2003.

eLapham, 1989.
The streambed flux generally was calculated using selflogging temperature sensors generally placed within the upper $1 \mathrm{ft}$ of streambed sediment (table 3 ). By examining a series of diagnostic plots created within VFLUX2, it was confirmed that the diurnal amplitude of the streambed temperature decreased with increased depth. If the diurnal amplitude for a given temperature was $0.2^{\circ} \mathrm{C}$ or less, then temperature data from that depth and all sensors below that depth were not used in streambed flux calculations. VFLUX2 calculates and reports the fluid flux at the midpoint depth between a temperature sensor pair. For example, site 411654096163701 has temperature sensors at 0.16 and $0.33 \mathrm{ft}$ below the streambed surface (table 3); therefore, VFLUX2 estimated the flux at the midpoint of $0.25 \mathrm{ft}$.

Following the advice of Briggs and others (2014), the Hatch Amplitude method (Hatch and others, 2006) was selected for the streambed flux analysis. The Hatch Amplitude method estimates flux accurately in situations where the flux is variable (Irvine and others, 2015) and where there may be potential strong upwelling conditions (Briggs and others, 2014). The first and last 48 hours of flux results are not included in the analyses, because the installation of vertical temperature arrays can alter flow paths within the streambed (Irvine and others, 2016) and edge effects created by automated filtering can produce misleading results (Gordon and others, 2012).

\section{Groundwater Movement and Interaction with Surface Water near the Confluence of the Platte and Elkhorn Rivers}

This section of the report describes streamflow and local climatic conditions near the confluence of the Platte and Elkhorn Rivers during this study. The characteristics of groundwater movement and interaction with surface water during low and high groundwater demand periods are also described. For the purposes of this report, low groundwater demand periods are defined as the months of September through May when streams are primarily sustained by groundwater discharge. During this period, runoff events are less common, and rates of evapotranspiration and groundwater pumping are minimal. Also for the purposes of this report, high groundwater demand periods are defined as the months of June, July, and August when groundwater pumping rates typically peak to meet row crop and municipal demands and evapotranspiration rates are at their highest. During this period, runoff events are common and are often the result of strong, localized convective storms that bring approximately 40 percent of the total annual precipitation (National Center for Environmental Information, 2018). 


\section{Streamflow and Local Climatic Conditions, 2016-18}

The local climatic conditions from 2016 to 2018 can be broadly characterized as having abnormally high precipitation. The annual precipitation rates measured at Valley, Nebr. (fig. 1), for the years of 2015, 2016, and 2017 were 40, 44, and 36 in., respectively (National Center for Environmental Information, 2018). The measured annual precipitation for 2018 was not available for Valley, Nebr., at the time this report was written; however, nearly 37 in. was reported in Omaha, Nebr. (fig. 1), for 2018 (National Weather Service, 2019). These rates were well above the 30 -year normal precipitation rate of 32.6 inches per year (National Center for Environmental Information, 2018), but were typical across the Elkhorn River Basin during the period of study. The measured daily discharge at the Elkhorn River at Waterloo, Nebr., streamflow-gaging station (06800500) remained above the long-term median for the entire period of study (fig. 6A; U.S. Geological Survey, 2018a). No major reservoirs or flow diversions are located along the main stem of the Elkhorn River and streamflow is generally reflective of the basin-wide climatic conditions. Runoff events, noted as upward spikes in the measured daily discharge record, were common and indicated periods of intense local rainfall in parts of the Elkhorn River basin. Dietsch and others (2009) determined that the flow of the Elkhorn River and some of the larger tributaries has been increasing over time.

The measured daily streamflow and median daily streamflow for the Platte River near Leshara, Nebr., streamflow-gaging station (06796500) is shown in figure $6 B$ (U.S. Geological Survey, 2018a). The streamflow of the Platte River remained normal or slightly above normal for the duration of this study. Exceptions include periods after local runoff events, which

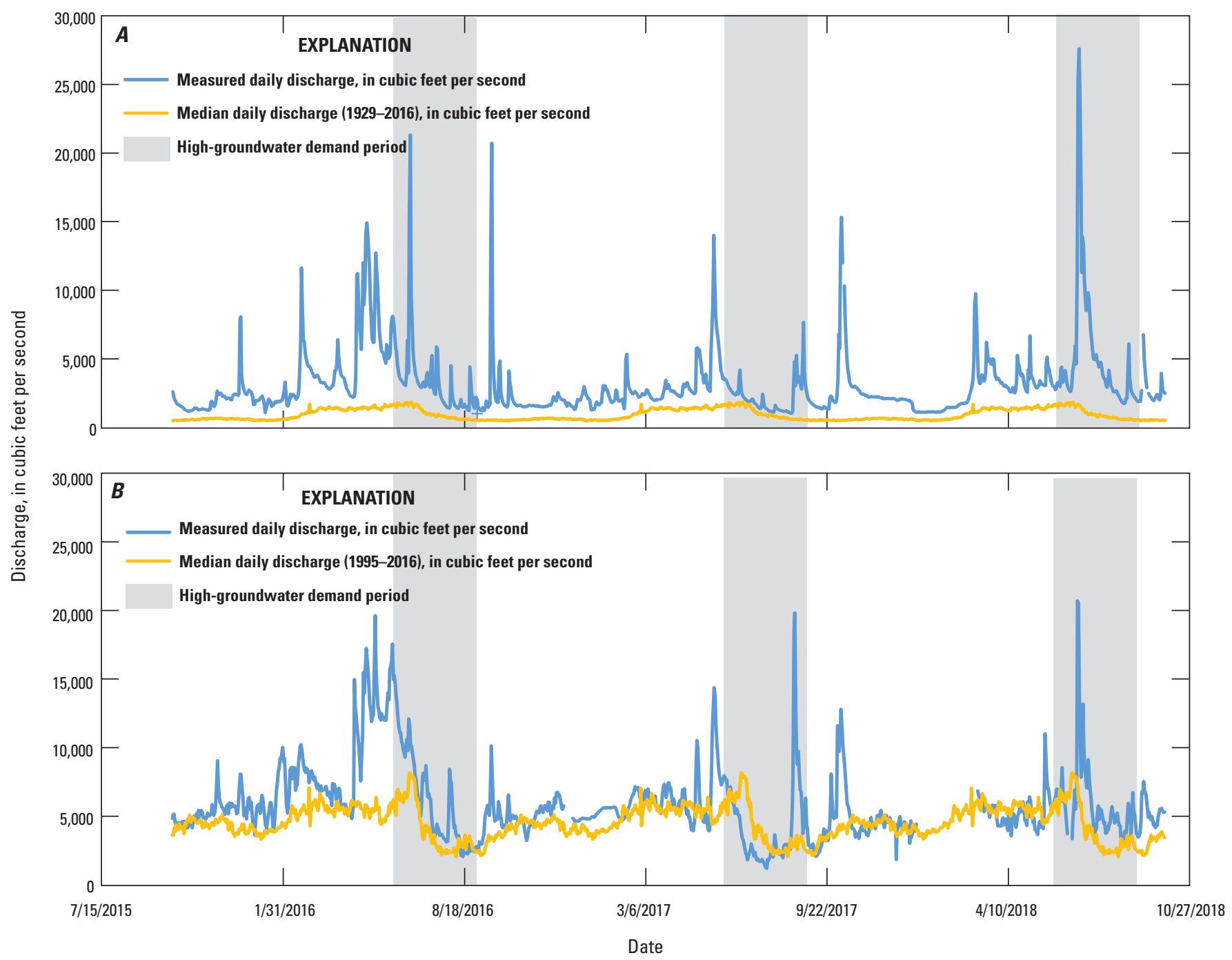

Figure 6. Measured daily discharge and median daily discharge. A, Elkhorn River at Waterloo, Nebraska, U.S. Geological Survey streamflow-gaging station (06800500); and B, Platte River near Leshara, Nebr., U.S. Geological Survey streamflow-gaging station (06796500). 
are upward spikes in the measured discharge record. The measured daily discharge during the spring of 2016 was often more than double the median daily discharge from 1995-2016 (fig. 6B). The flow of the Platte River is affected by local climatic conditions and by releases from upstream reservoirs in Nebraska and Wyoming. Higher-than-normal reservoir releases in spring of 2016 were timed to accommodate runoff from spring snowmelt in the headwaters of the Platte River system.

\section{Groundwater Movement Characteristics During Low Groundwater Demand Periods}

Recorder wells installed along a transect from west of the Platte River near Leshara, Nebr., streamflow-gaging station (06796500) eastward to the Elkhorn River at Waterloo, Nebr., streamflow-gaging station (06800500) indicate the northwest to southeast movement of water (fig. $2 A$; fig. 7). Water moves from the west across the Platte River channel towards the Elkhorn River. During low groundwater demand periods, the water level at well LPNNRD-80 (fig. 1) was consistently 2 to $3 \mathrm{ft}$ higher than the Platte River, indicating groundwater discharges into the Platte River from the west. Groundwater generally moves from the Platte River east towards the Elkhorn River; however, there was one exception during the fall of 2017 when approximately $10 \mathrm{in}$. of precipitation was recorded, which was 150 percent higher than normal (National Center for Environmental Information, 2018). As a result, local groundwater levels increased, creating a temporary groundwater ridge. Groundwater moved west towards the Platte River during September and October before returning to flow eastward towards the Elkhorn River (fig. 7). Periods of intense local precipitation translated into smaller increases in water-level elevation on the Platte River when compared to the Elkhorn River (fig. 7). Water levels measured at the Valley Park, MUD95, and Valley-15 wells indicate a consistent west to east movement of water across the entire period of study.

A synoptic water-level survey was completed October 31 to November 3, 2016, to assess groundwater and surface-water flow conditions within the study area during a low groundwater demand period. The survey used water levels measured from 10 irrigation wells, 3 observation wells, 14 recorder wells, and surveyed elevations from 91 surface-water features over a short period of time to provide a snapshot of groundwater and surface-water flow conditions (figs. $3 A$ and $B$ ). For each recorder well, the median recorded groundwater level from October 31 to November 3 was computed and used. Streamflow measurements were collected within the study area at 10 locations on the Elkhorn River and four tributaries (fig. $3 B$; table 2). The daily discharge reported at the Platte River near Leshara and Elkhorn River at Waterloo, Nebr., streamflow-gaging stations is shown in figure $3 B$ and reported in table 2. The discharge of the Platte River was slightly above normal and the discharge of the Elkhorn River was well above normal during this period (fig. 6). There were no runoff events in the 3 weeks preceding the synoptic water-level and streamflow survey, therefore the water levels and streamflow shown in figures $3 A$ and $B$ provide an accurate portrayal of hydrologic conditions within the study area.

A water-table contour map was created (fig. $3 A$ ) using the measured water levels and supporting streamflow measurements. In the northern portion of the study area, groundwater flows towards tributaries of the Elkhorn River, which include Rawhide Creek (Old Channel), Rawhide Creek, and Big Slough. These tributaries effectively act as groundwater drains across an area where the alluvial aquifer thins and is finer-grained compared to areas to the south (Carney and others, 2015; Korus and others, 2012). Groundwater discharges to the tributary streams, increasing flow before reaching the Elkhorn River. One notable exception is the upper portion of Rawhide Creek (Old Channel) where flow decreases from 30.9 to 22.5 cubic feet per second $\left(\mathrm{ft}^{3} / \mathrm{s}\right)$. Within the city of Fremont (fig. 1) dewatering wells pump groundwater into Rawhide Creek (Old Channel) to lower the water table. Some of the pumped groundwater recharges the underlying alluvial aquifer farther downstream and increases groundwater seepage into the upper reach of Rawhide Creek (Old Channel; fig. 3B; table 2).

South of Big Slough, along the transect of recorder wells, groundwater flow is to the southeast towards the Elkhorn River. The alluvial aquifer across this portion of the study area is much thicker and coarser grained compared to the north (Carney and others; 2015; Korus and others, 2012). From the streamflow-gaging station at Waterloo (06800500) to the Q Street Bridge (06800800), streamflow measurements indicate an increase in flow of approximately $80 \mathrm{ft}^{3} / \mathrm{s}$ to the Elkhorn River (fig. 3B; table 2). Farther to the south, a network of road ditches and small streams capture groundwater from the north and the west and discharge into the Tributary to the Elkhorn River (fig. 3B; table 2).

Aerial TIR data were collected on December 15, 2017, during a low groundwater demand period (fig. 5). Flow conditions were typical during the period of study in that the flow of the Platte River was near normal and the flow of the Elkhorn River was well above normal (fig. 6) and water levels indicated there were no runoff events in the weeks leading up to aerial TIR imagery collection. Inspection of the aerial TIR imagery (Hobza and Strauch, 2019) revealed there were very few, if any, focused groundwater discharge points along the west bank of the Elkhorn River. Riparian vegetation seemed to retain heat that was approximately the same temperature of the stream surface and could have obscured some focused groundwater discharge. The lack of focused groundwater discharge points indicates a lack of strong regional gradients along the margins of the Elkhorn River; therefore, groundwater discharge is more diffuse and occurs through the streambed.

A downstream temperature profile was created by plotting the extracted surface temperatures along a digitized centerline of the Elkhorn River and plotting against distance upstream and downstream from the Elkhorn River at Waterloo, Nebr., streamflow-gaging station (fig. 8). The downstream 


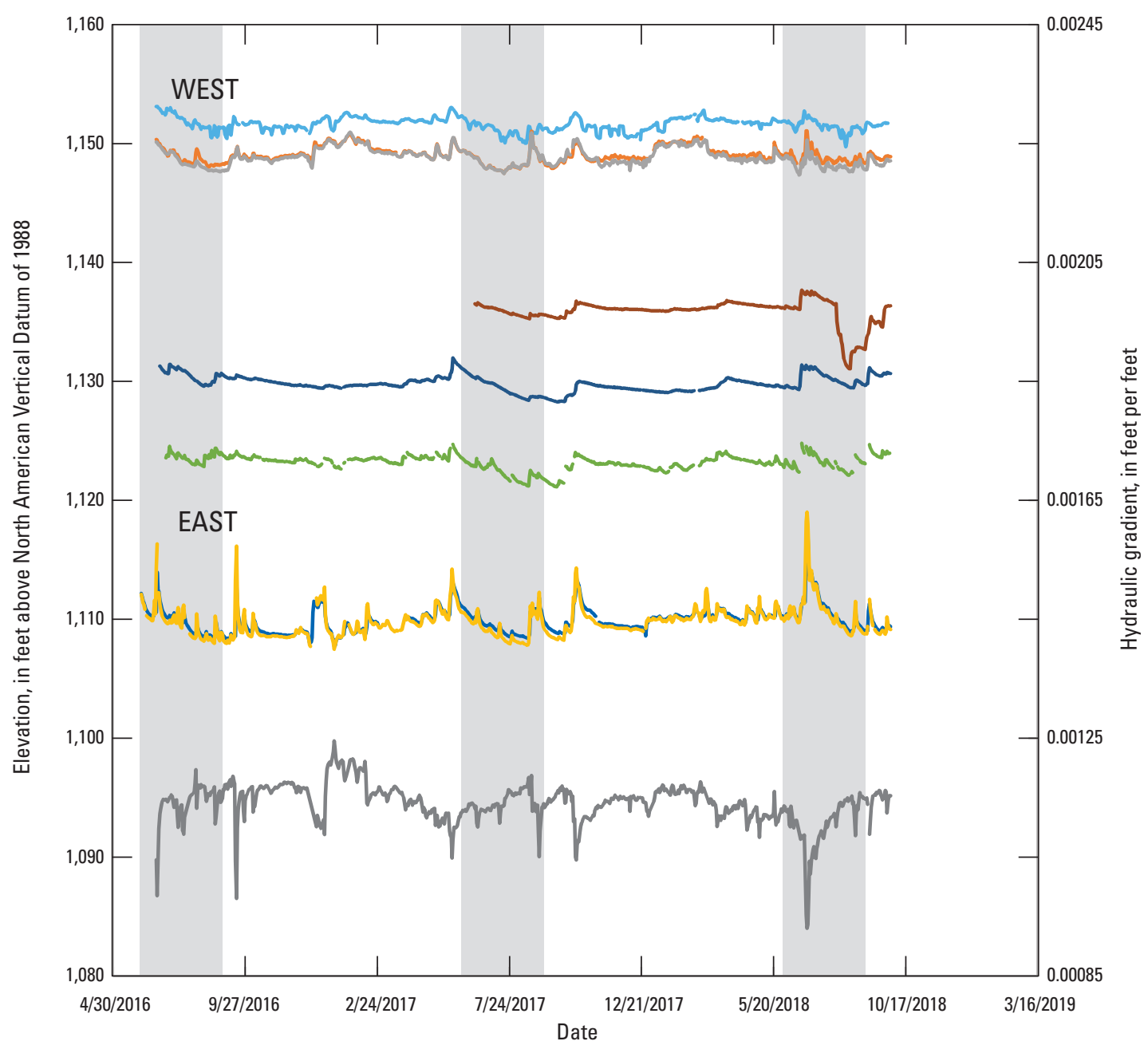

EXPLANATION

[LPNRD, Lower Platte North Natural Resources District; MUD, Omaha Metropolitan Utilities District]

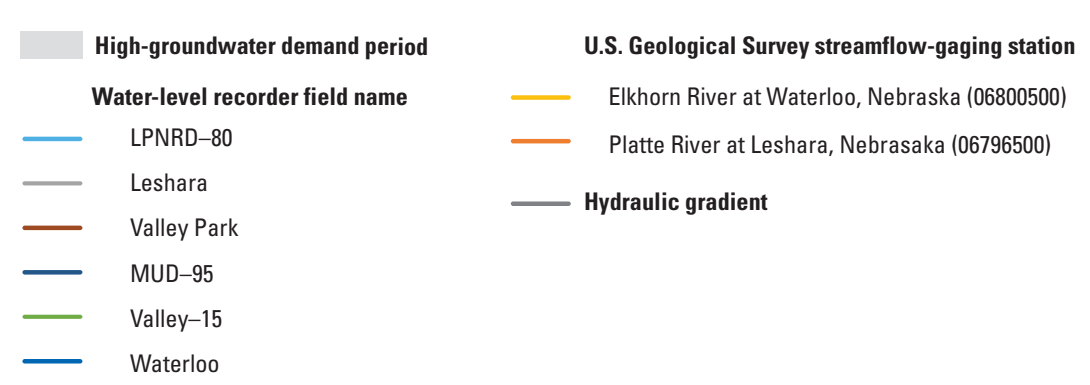

Figure 7. Water-level elevation from recorder wells and streamflow-gaging stations, and hydraulic gradient 2016-18. 
temperature profile indicates that surface temperatures of the Elkhorn River near the Elkhorn River at Waterloo, Nebr., streamflow-gaging station (06800500) varied $\pm 0.1^{\circ} \mathrm{C}$ around a central value of $3.1^{\circ} \mathrm{C}$. Around $3 \mathrm{mi}$ downstream from the Elkhorn River at Waterloo, Nebr., streamflow-gaging station the temperature increases to approximately $3.4^{\circ} \mathrm{C}$ (figs. 5 and 8). A similar temperature increase is noticed with the recorded temperature at the self-logging temperature sensors at Center Street and Q Street Bridges (figs. 5 and 8). Approximately $2.5 \mathrm{mi}$ downstream from the Elkhorn River at Waterloo, Nebr., streamflow-gaging station, the Elkhorn River bends from flowing south-southeast to south-southwest. The southwest direction is roughly perpendicular to the direction of groundwater flow mapped in figure $3 \mathrm{~A}$ and coincides with the increase in stream temperature. The temperature increase indicates that groundwater discharge received by the Elkhorn River is focused along a reach beginning $2.5 \mathrm{mi}$ downstream from the streamflow-gaging station to $1 \mathrm{mi}$ downstream from the Q Street Bridge (figs. 5 and 8). The Elkhorn River turns to the southeast along the last $0.5 \mathrm{mi}$ of the reach where aerial TIR was collected. Surface temperatures decrease across this short reach, indicating that the flow direction of the Elkhorn River is an important control on groundwater discharge.

The temperature data shown in figure 8 can be used to estimate the volume of groundwater discharged to the Elkhorn River from the Elkhorn River at Waterloo, Nebr., streamflowgaging station (06800500) to Q Street Bridge (06800800) using the following equation:

$$
\text { Qin Tin }+ \text { Qgw Tgw }=\text { Qout Tout }
$$

where

Qin is the discharge of the Elkhorn River
measured at the Elkhorn River at
Waterloo, Nebr., streamflow-gaging station
$(06800500)$;
is the temperature measured by the thermistor
at the Elkhorn River at Waterloo, Nebr.,
streamflow-gaging station (06800500);
is the volume of groundwater discharged to
the Elkhorn River between the Elkhorn
River at Waterloo, Nebr., streamflow-
gaging station (06800500) and the Q Street
Bridge (06800800);
is the temperature of the groundwater
discharged to the Elkhorn River;
Tgw the discharge of the Elkhorn River at the
Q Street Bridge (06800800); and
is the temperature measured by the self-
logging temperature sensors for the
Elkhorn River at the Q Street bridge
(06800800).

The use of this equation assumes that the stream is well mixed in the location of the temperature sensors, which has been demonstrated in the location of the streamflowgaging station where cross-sectional measurements of water temperature, specific conductance, and dissolved oxygen have been collected in support of continuous water-quality monitoring (U.S. Geological Survey, 2018a). The second assumption is that water temperature is a conservative tracer and groundwater discharged to the river is not affected by cooler air temperatures. Water temperature is generally not regarded as a conservative tracer; however, given the short reach and short travel times where the imagery was collected, the discharge calculations can provide some meaningful estimates.

Equation 2 can be rearranged to solve for $Q g w$ using temperature data from the aerial TIR imagery and from selflogging temperature sensors and thermistor readings collected at upstream (Tin) and downstream locations (Tout). The downstream temperature profile shows a smaller temperature increase compared to the temperature sensors data deployed at Q Street and the Elkhorn River at Waterloo, Nebr., streamflow-gaging station (fig. 8). The smaller temperature increase would translate to a lower bound for an estimate for $Q g w$. Conversely, using the temperature sensor data could provide an upper bound for the $Q g w$ estimate. The sources and values used to estimate $Q g w$ are given in table 5.

The range in estimates for the volume of groundwater discharged to the Elkhorn River $(Q g w)$ varies by a factor of four. The estimate provided by streamflow measurements measured during the synoptic water-level survey was $80 \mathrm{ft}^{3} / \mathrm{s}$, which fits within the range of estimates provided in table 5 and more closely approximates the estimate for $Q g w$ using the aerial TIR imagery.

\section{Groundwater Movement Characteristics During High Groundwater Demand Periods}

During periods of high groundwater demand, water levels indicated that water moved from the northwest across the Platte River to the southeast towards the Elkhorn River (figs. $4 A$ and 7). There were exceptions during high groundwater demand period in 2017 when the water levels in the Leshara well and the Platte River indicated westward groundwater movement towards the Platte River. In late July of 2018, localized groundwater pumping dropped the groundwater level near Valley City Park well by more than $5 \mathrm{ft}$. Water levels recovered shortly after pumping ceased in late September of 2018 (fig. 7).

A synoptic water-level survey was completed July 31 to August 3, 2017, to assess groundwater and surface-water flow conditions within the study area during a high groundwater demand period. The survey used water levels measured from 9 irrigation wells, 3 observation wells, and 12 recorder wells and surveyed elevations from 95 surface-water features (fig. 4A). For each recorder well, the median (daily) recorded groundwater level from July 31 to August 2 was computed and used. Streamflow was measured near Arlington (fig. 1) in addition to the 10 locations measured during the synoptic water-level survey completed during a low groundwater demand period (fig. 4B; table 2). The daily discharge reported 


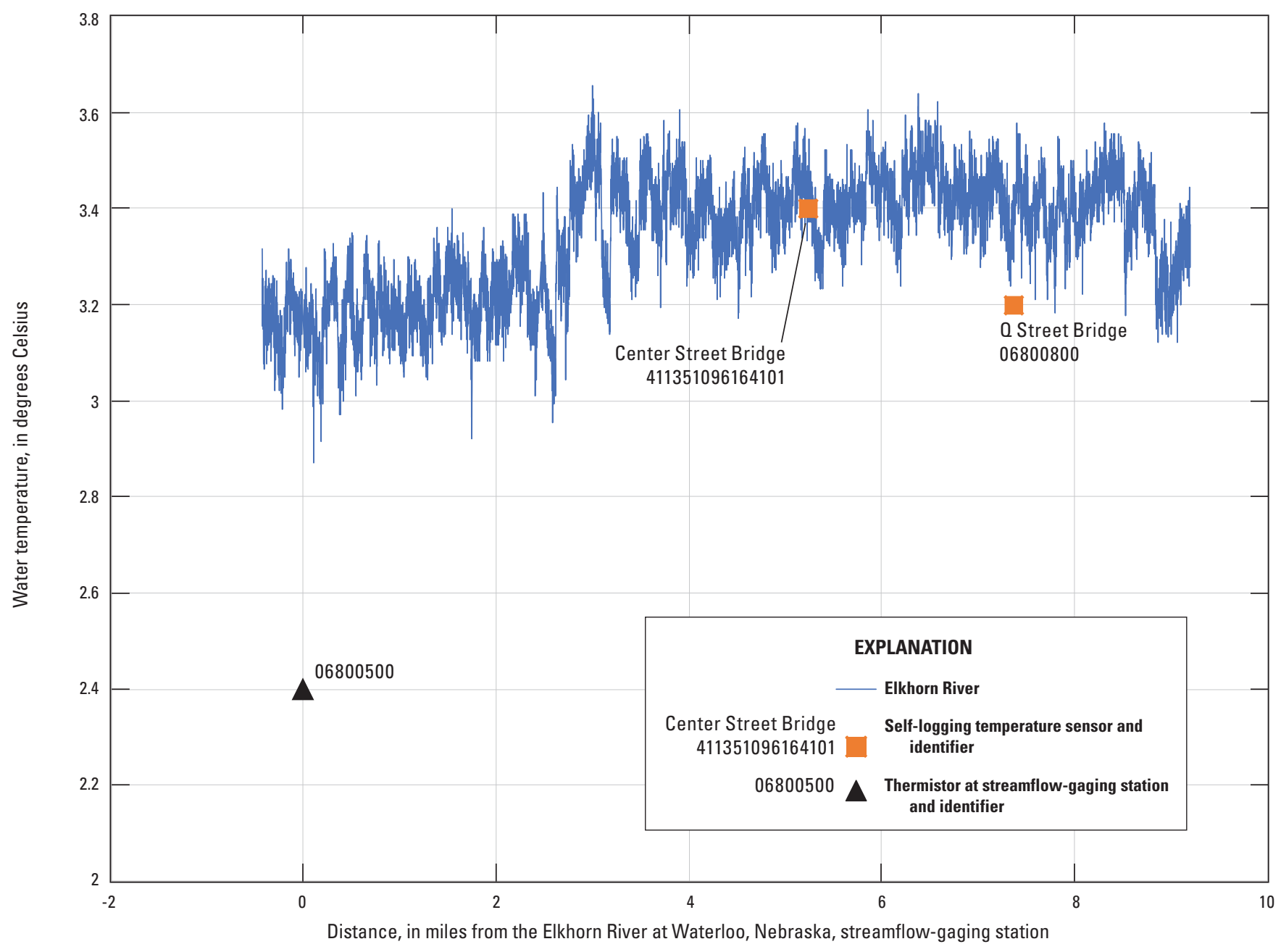

Figure 8. Graph showing downstream temperature profile of the Elkhorn River from 0.5 mile upstream from the Elkhorn River at Waterloo, Nebraska, streamflow-gaging station to 1 mile downstream from the 0 Street Bridge. Downstream temperature profiles were created from aerial thermal infrared imagery collected December 15, 2017.

Table 5. Discharge and temperature data used in equation 2 to estimate groundwater discharge to the Elkhorn River.

[Tin, temperature measured by the thermistor at the Elkhorn River at Waterloo, Nebraska, streamflow-gaging station (06800500); Tout, temperature measured by the self-logging temperature sensors for the Elkhorn River at the Q Street Bridge streamflow-gaging station (06800800); Qin, daily discharge from the Elkhorn River at Waterloo, Nebr., streamflow-gaging station (U.S. Geological Survey station 06800500), December 15, 2017; Tgw, groundwater temperature recorded at recorder well 411736096170201 rounded to the nearest degree; $Q g w$, volume of groundwater discharged to the Elkhorn River between the Elkhorn River at Waterloo, Nebr., streamflow-gaging station (06800500) and the Q Street Bridge (06800800)]

\begin{tabular}{lccccc}
\hline \multicolumn{1}{c}{ Source of Tin and Tout } & $\begin{array}{c}\text { Qin, } \\
\text { in cubic feet } \\
\text { per second }\end{array}$ & $\begin{array}{c}\text { Tin, } \\
\text { in degrees } \\
\text { Celsius }\end{array}$ & $\begin{array}{c}\text { Tgw, } \\
\text { in degrees } \\
\text { Celsius }\end{array}$ & $\begin{array}{c}\text { Tout, } \\
\text { in degrees } \\
\text { Celsius }\end{array}$ & $\begin{array}{c}\text { Qgw, } \\
\text { in cubic } \\
\text { feet per second }\end{array}$ \\
\hline Temperature sensors & 2,070 & 2.4 & 13 & 3.2 & 170 \\
Aerial thermal infared imagery & 2,070 & 3.2 & 13 & 3.4 & 43 \\
\hline
\end{tabular}


at the Platte River near Leshara and Elkhorn River at Waterloo, Nebr., streamflow-gaging stations is shown in figure $4 B$ and reported in table 2. The discharge of the Platte River was normal, and the discharge of the Elkhorn River was well above normal (fig. $6 A, B$ ). There were no runoff events in the 3 weeks preceding the synoptic water-level and streamflow survey, therefore the water levels and streamflow shown in figures $3 A$ and $B$ provide an accurate portrayal of hydrologic conditions within the study area.

A water-table contour map was created (fig. $4 A$ ) using the measured water levels and supporting streamflow measurements. Water levels and groundwater flow directions were similar to the low groundwater demand synoptic water-level survey; however, there were some key differences. Generally speaking, water levels measured in wells and surface-water features were lower during the high groundwater demand synoptic water-level survey. The largest declines in water levels, as large as $5 \mathrm{ft}$, were seen in observation wells within and near the Platte West well field in the southern part of the study area (fig. 1). The water-level elevation decreased in surface-water features near the Platte West well field, which are drained by the Tributary to the Elkhorn River (fig. 4A). Decreases in surface-water water levels as large as $1.4 \mathrm{ft}$ were surveyed along the Tributary to the Elkhorn River (fig. 1).

Streamflow measurements collected during the high groundwater demand period indicate less surface-water flow as compared to the low groundwater demand period (fig. $3 B$ and fig. $4 B$, table 2). The streamflows measured in Rawhide Creek and Big Slough decreased approximately by a factor of 3 during the high groundwater demand period. The streamflow measured in the Elkhorn River at the streamflow-gaging station at Waterloo indicates a decrease of 25 percent during the high groundwater demand period. Examining the measured streamflow during the high groundwater demand period, there is an increase in streamflow of approximately $150 \mathrm{ft}^{3} / \mathrm{s}$ between the Elkhorn River near Arlington and the Elkhorn River at Waterloo streamflow-gaging station. Approximately $34 \mathrm{ft}^{3} / \mathrm{s}$ is the result of combined surface-water inflows from Rawhide Creek, Rawhide Creek (Old Channel), and Big Slough. The remaining flow (about $116 \mathrm{ft}^{3} / \mathrm{s}$ ) was received as groundwater discharge.

The decrease in water-levels measured during the high groundwater demand period appears to have a substantial effect on streamflows in the southern part of the study area. Between the streamflow-gaging station at Waterloo and the $\mathrm{Q}$ Street Bridge (fig. $4 B$ ), the Elkhorn River loses approximately $80 \mathrm{ft}^{3} / \mathrm{s}$ (table 2). At this same time, the streamflow of the Tributary to the Elkhorn River was about $0.6 \mathrm{ft}^{3} / \mathrm{s}$, which was a decrease of $10 \mathrm{ft}^{3} / \mathrm{s}$ when compared to the low groundwater demand period (fig. $4 B$, table 2). Interestingly the interpreted groundwater flow paths shown in figure $4 A$ indicate that the Elkhorn River should be receiving groundwater discharge between the streamflow-gaging station at Waterloo and the Q Street Bridge. To confirm this counterintuitive and unexpected result, streamflow was measured again on August 7 at both locations and indicated a loss in streamflow of $110 \mathrm{ft}^{3} / \mathrm{s}$ across this reach from the streamflow-gaging station at Waterloo and the Q Street Bridge (table 2).

Regarding the unexpected result, it is hypothesized that in the southern part of the study area, west of the Elkhorn River, the slope or gradient of the groundwater-level surface steepens, and the groundwater flow direction deflects to the south. The steeper gradient and different flow direction effectively decreases the amount of groundwater discharge received by the Elkhorn River as groundwater flows south towards its confluence with the Platte River. Groundwater moves downgradient as underflow where it would be received as groundwater discharge to the Platte River or the Elkhorn River south of Q Street closer to their confluence. A decrease in streamflow in the Tributary to the Elkhorn River near Q Street may be caused by the steeper groundwater gradient and increased pumping at the Platte West well field that would most likely capture some groundwater discharge from its headwaters to the west (fig. $4 B$ ).

During late summer of 2017 streambed flux rates were estimated at 15 vertical temperature array sites (table 3; figs. $9 B$ and $10 B$ ) at two locations along the Elkhorn River (fig. 1). Streambed flux rates indicate water exchanged between the Elkhorn River and the underlying alluvial aquifer across the streambed. In this report, a positive streambed flux rate indicates the stream is gaining or receiving groundwater discharge. Conversely, a negative streambed flux rate indicates the stream is losing or the alluvial aquifer is receiving groundwater recharge. Streambed temperature data were collected in late summer of 2017 when streamflow would typically be at its minimum increasing the accessibility of the steam channel for data collection. Outside of a high flow 2-week window (August 16-30), streamflow remained steady during the entire data collection periods for the Waterloo SBF and Elkhorn Crossing SBF locations. Small runoff events occurred on July 13 and 27, and September 18 (fig. 6). Since the July 13 runoff event occurred within 48 hours of the vertical temperature deployment period, these streambed flux rates were excluded from further analysis. The second largest runoff event occurred on July 27 when the stage rose $0.9 \mathrm{ft}$ at the Elkhorn River near Waterloo streamflow-gaging station. Because streamflow rates were steady during the data collection periods at both sites, streambed flux rates at each vertical temperature array location are summarized in box plots (Helsel and Hirsch, 2002; figs. $9 A$ and $10 A$ ) to provide a concise visual summary.

Vertical temperature arrays were installed into the streambed at nine sites at the Waterloo SBF location downstream from a railroad bridge (table 3; fig. 9B). Measured streamflow generally decreased throughout the period of streambed temperature data collection except for one runoff event on July 27. A box plot shown in figure $9 A$ displays the distribution of flux rates for sites shown on the map in figure $9 B$. Streambed flux rates are given at the midpoint depth between two temperature sensors and were limited to within $1 \mathrm{ft}$ of the streambed surface. The flux rates shown in figure $9 A$ are a one-dimensional representation of three-dimensional hyporheic flow. At most 


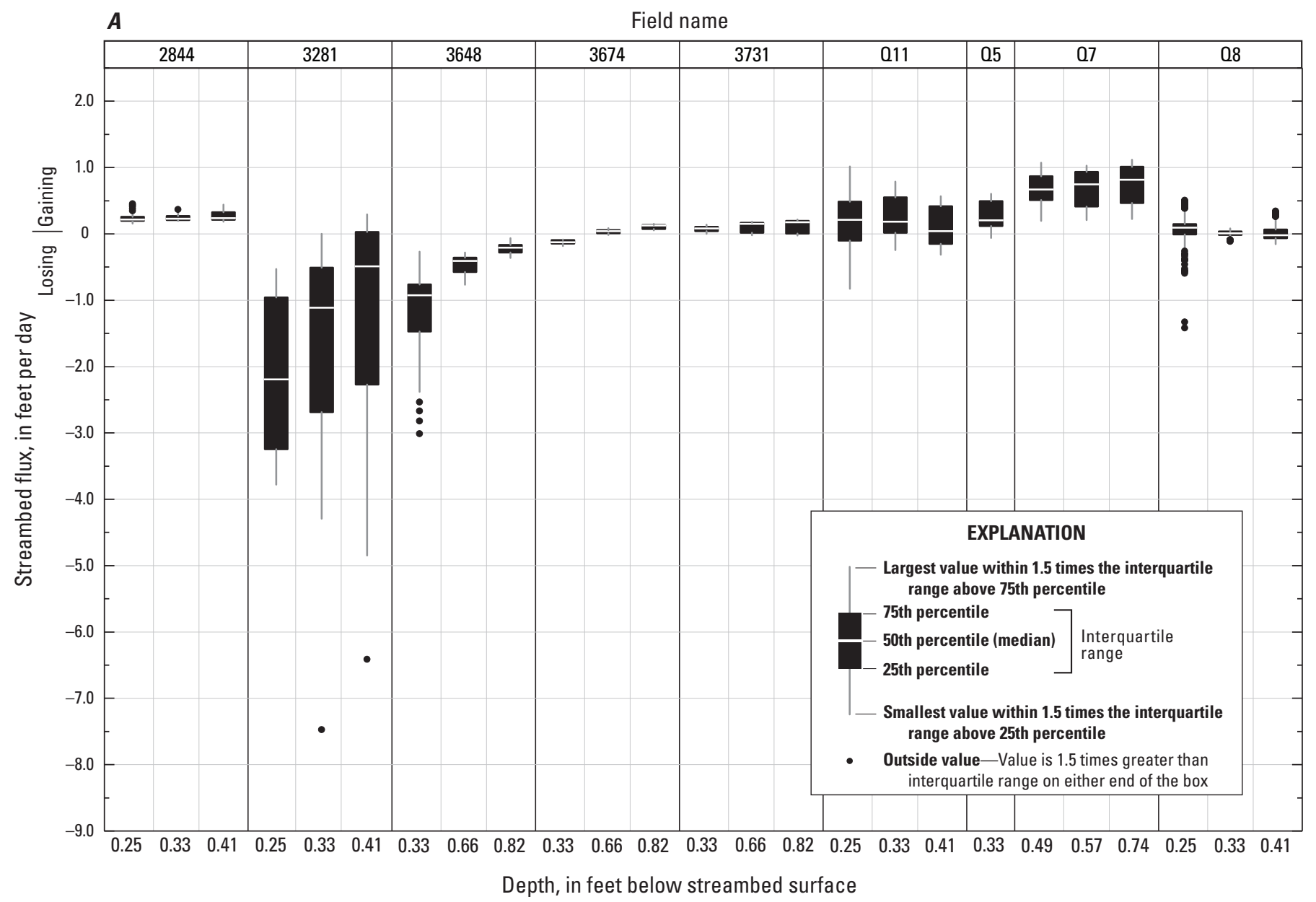

Figure 9. Waterloo streambed flux site on the Elkhorn River. $A$, Boxplot showing distribution of streambed flux rates at the midpoint between the sensors for each vertical temperature array, July 12-August 16, 2017; and $B$, map showing vertical temperature array locations.

vertical temperature array sites, flux rates were both positive and negative, which is consistent with the findings of Chen and others (2009), who noted both positive and negative vertical head gradients along a reach of the Elkhorn River upstream from the study area. Streambed flux rates generally ranged from $-7.5 \mathrm{feet} /$ day (ft/d) to $1.1 \mathrm{ft} / \mathrm{d}$ (fig. $9 A$ ). Some larger, positive streambed flux rates were closer to the right bank for sites 2844, Q7, and Q11 and are likely the result of the southeastern movement of groundwater across the study area. Some of the highest streambed flux rates are estimated at site 3281 in an area of strong downwelling. The variability in the direction and magnitude of streambed flux rates indicates that strong regional groundwater gradients are not driving groundwater discharge, and hyporheic exchange is the dominant groundwater/surface-water exchange process.

Vertical temperature arrays were installed at six sites at the Elkhorn Crossing SBF location. Higher-than-normal streamflow during the period of data collection limited access to one submerged shelf along the right bank (fig. 10B).

Streamflow was generally decreasing throughout the period of streambed temperature data collection (fig. 6), and stream stage measured at the Elkhorn River at Waterloo, Nebr., streamflow-gaging station fell approximately $1.5 \mathrm{ft}$ (fig. 7). One runoff event on September 18 increased the stream stage at the Elkhorn River at Waterloo, Nebr., streamflow-gaging station by $0.4 \mathrm{ft}$. Like the Waterloo SBF location, the calculated streambed flux rates at the Elkhorn Crossing SBF location indicated both gaining and losing conditions. The calculated streambed flux rates at the Elkhorn Crossing SBF location ranged from -2.7 to $0.6 \mathrm{ft} / \mathrm{d}$ and most flux rates were within -0.5 to $0.5 \mathrm{ft} / \mathrm{d}$. As with the Waterloo SBF location, the calculated streambed flux rates indicate a lack of strong regional groundwater gradients, and hyporheic exchange is the dominant groundwater/surface-water exchange process.

\section{Spatial and Seasonal Trends in Groundwater Movement Between the Platte and Elkhorn Rivers}

The previous two sections describe groundwater and surface-water interaction characteristics for high and low 


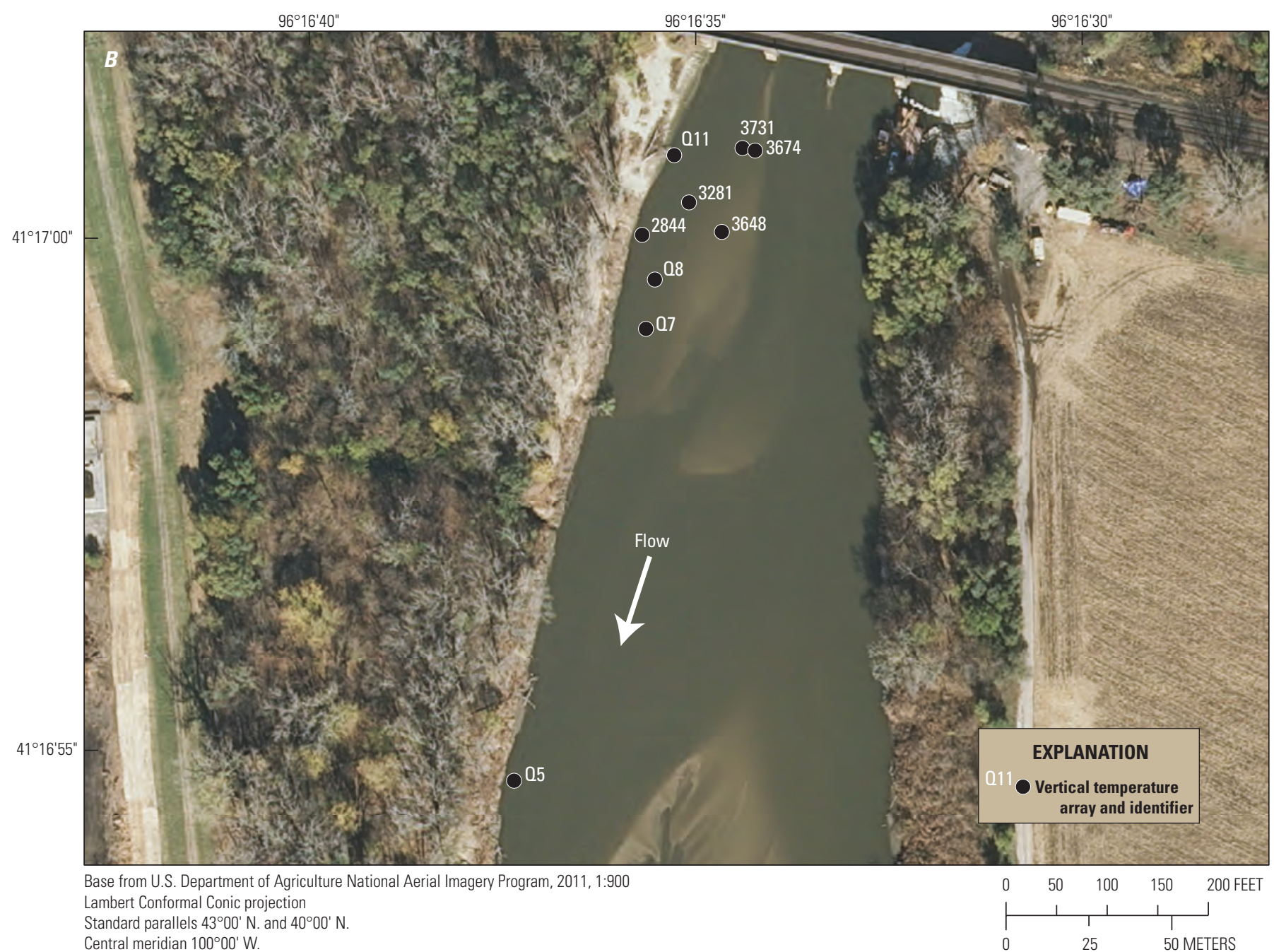

Figure 9. Waterloo streambed flux site on the Elkhorn River. $A$, Boxplot showing distribution of streambed flux rates at the midpoint between the sensors for each vertical temperature array, July 12-August 16, 2017; and B, map showing vertical temperature array locations. - Continued

groundwater demand periods from 2016 to 2018. Continuous streamflow and water-level data were interpreted to examine seasonal characteristics in groundwater movement and interaction with surface water between the Platte and Elkhorn Rivers. Although the streamflow for the Platte and Elkhorn Rivers and their tributaries was less during the high groundwater demand period, the hydraulic gradient (calculated along the transect of recorder wells) was identical ( 0.0012 foot per foot $[\mathrm{ft} / \mathrm{ft}]$ ) during the high and low groundwater demand synoptic water-level and streamflow surveys (fig. 7). The hydraulic gradient between Platte and Elkhorn Rivers generally remained between 0.0011 and $0.0012 \mathrm{ft} / \mathrm{ft}$. It can be inferred that the hydraulic gradient, which is the only temporally variable factor in Darcy's Law (Freeze and Cherry, 1979), is consistent throughout the study period and groundwater flow does not vary appreciably along this transect. There were exceptions during runoff events, which raised the stage of the
Elkhorn River and decreased the estimated hydraulic gradient (fig. 7).

The northern part of the study area (north of the transect of recorder wells) shows consistent groundwater and tributary flow for low and high groundwater demand periods. Based on streamflow measurements, approximately $34 \mathrm{ft}^{3} / \mathrm{s}$ (equivalent to 25,000 acre-feet per year [acre-ft/yr] ) and $39 \mathrm{ft}^{3} / \mathrm{s}$ $(28,000 \mathrm{acre}-\mathrm{ft} / \mathrm{yr})$ of water is received by the Elkhorn River as tributary flow from Big Slough, Rawhide Creek (Old Channel), and Rawhide Creek during the low and high groundwater demand periods, respectively.

In the southern part of the study area (south of the transect of recorder wells), tributary flow is much more variable and dependent on groundwater demand and flow conditions of the Platte River. Prior to the synoptic water-level and streamflow survey for the low groundwater demand period, the streamflow of the Platte River was slightly above normal 


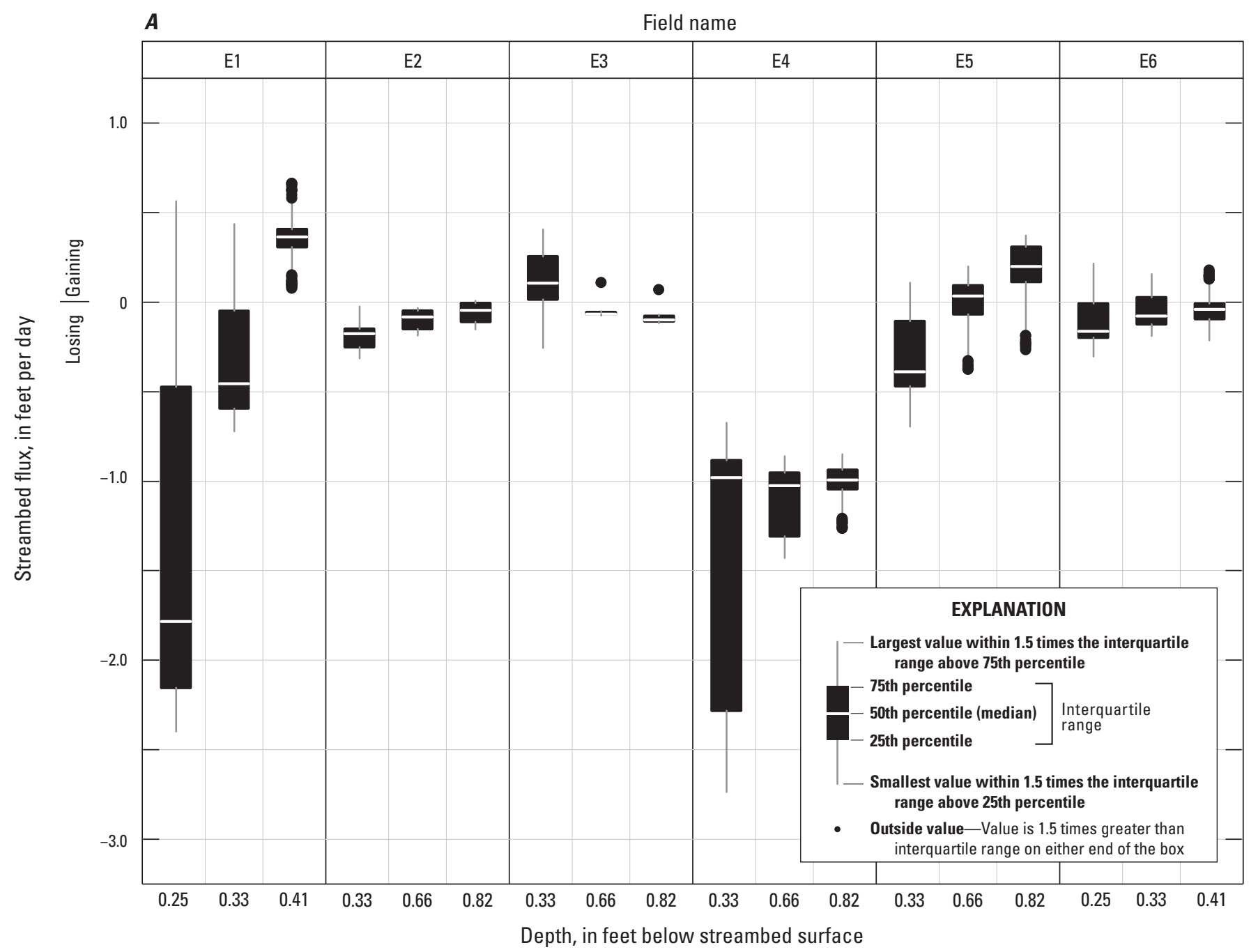

Figure 10. Elkhorn Crossing streambed flux site on the Elkhorn River. A, Boxplot showing distribution of streambed flux rates at the midpoint between the sensors for each vertical temperature array, August 30-September 21, 2017; and $B$, map showing vertical temperature array locations.

(fig. $6 B$ ), resulting in groundwater recharge and higher groundwater levels. During this period groundwater flow was to the southeast and captured by the Tributary to the Elkhorn River. Periods of lower than normal streamflow in the Platte River resulted in lower groundwater levels in areas near the Tributary to the Elkhorn River. Small decreases in the groundwater levels, such as those measured during the high groundwater demand period, can cause substantial changes in the streamflow of the Tributary to the Elkhorn River (table 2; fig. $4 B$ ). The streamflow measured during the synoptic waterlevel and streamflow survey for the high groundwater demand period had decreased by nearly a factor of 20 when compared to the low groundwater demand period. Using the streamflow measured during both synoptic water-level and streamflow surveys, the Tributary to the Elkhorn River provides about $8 \mathrm{ft}^{3} / \mathrm{s}(6,000 \mathrm{acre}-\mathrm{ft} / \mathrm{yr})$ of water to the Elkhorn River.

The volume of groundwater discharge received by the Elkhorn River was estimated by examining the changes in streamflow between measurement locations. Streamflow measurements indicate that the groundwater discharge received by the Elkhorn River in the southern part of the study area is seasonally variable, making it difficult, if not impossible, to estimate an annual value. Between the Elkhorn River at Waterloo, Nebr., streamflow-gaging station and the Q Street Bridge, streamflow measurements collected during the low groundwater demand period indicated a gain of $80 \mathrm{ft}^{3} / \mathrm{s}$ $(58,000 \mathrm{acre}-\mathrm{ft} / \mathrm{yr})$, which is comparable to the gain estimated using aerial TIR imagery and water temperature data. Streamflow measurements collected during the high groundwater demand period indicate a loss of $80 \mathrm{ft}^{3} / \mathrm{s}(58,000$ acre-ft/yr) for this reach. The term "loss" should be used with caution when referring to streamflow of the Elkhorn River in assessing water supply conditions in the lower Platte River system. Most likely, flow from the Elkhorn River, which is "lost" to the groundwater system, will later discharge to surface water closer to the confluence of the Platte and Elkhorn Rivers as 


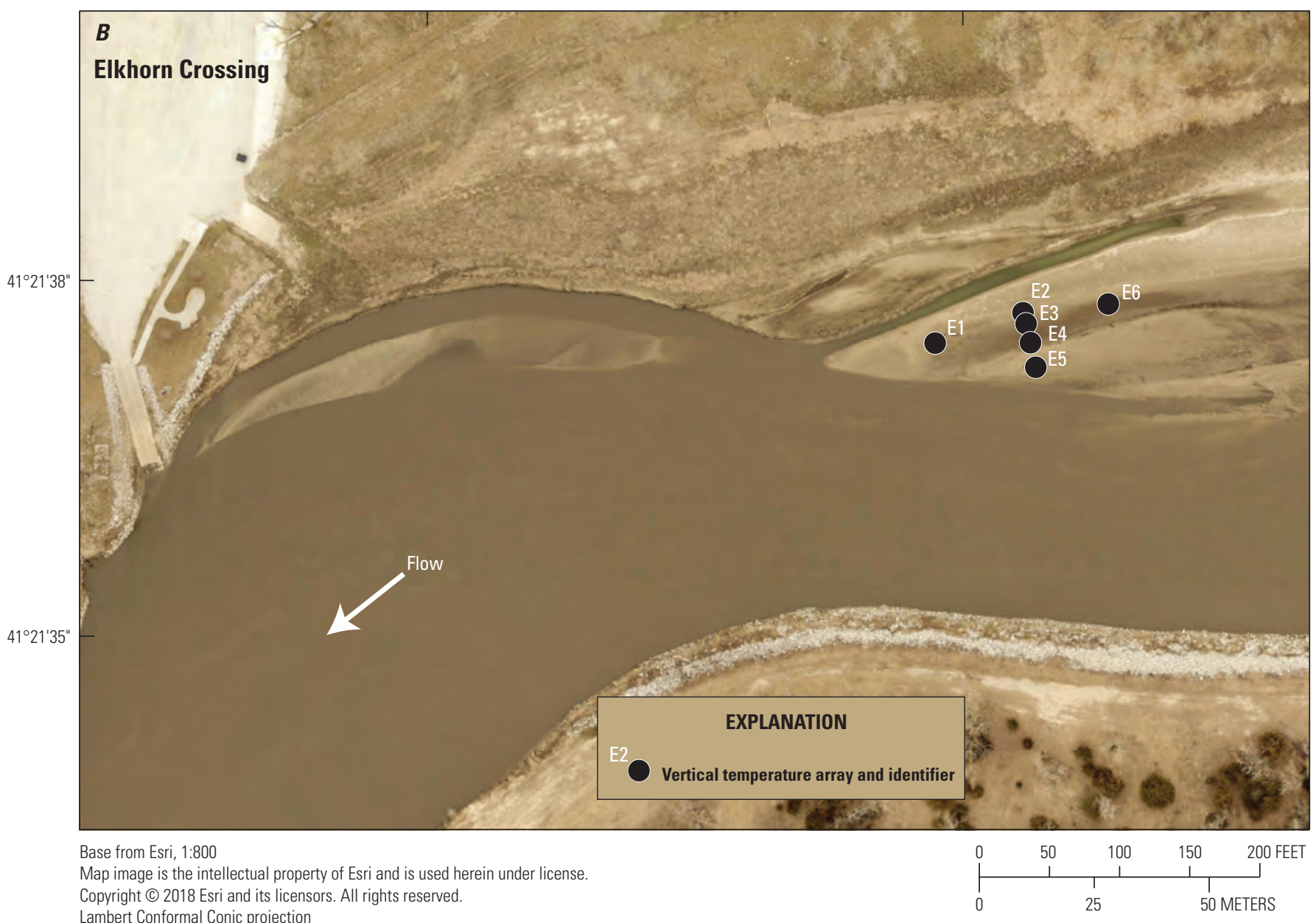

False Easting 1640417, False Northing 0

Central meridian $100^{\circ} 00^{\prime} \mathrm{W}$.

Figure 10. Elkhorn Crossing streambed flux site on the Elkhorn River. A, Boxplot showing distribution of streambed flux rates at the midpoint between the sensors for each vertical temperature array, August 30-September 21, 2017; and $B$, map showing vertical temperature array locations.-Continued

underflow. A calibrated groundwater flow model of the study area likely is required to predict the fate of this water and to quantify groundwater discharge during varying hydrologic conditions along this reach.

Aerial TIR imagery indicated that much of the groundwater discharge in the southern part of the study area is focused across a 3-mi reach where the Elkhorn River turns southwest, perpendicular to the regional groundwater flow direction. Points of focused groundwater discharge were not detected with aerial TIR imagery, indicating that groundwater discharge is diffuse rather than concentrated at focused points driven by strong regional groundwater flow gradients. Temperaturebased streambed flux estimates indicated that strong regional groundwater gradients are not driving groundwater discharge, and hyporheic flow is the dominant groundwater/surface-water exchange process.

\section{Summary}

The State of Nebraska requires a sustainable balance between long-term water supplies and uses of groundwater and surface water and requires Natural Resources Districts (NRDs) to include the effect of groundwater use on surfacewater systems as part of their respective integrated management plans. Recent droughts in Nebraska (2000-6; 2012-13) have amplified concerns about the long-term sustainability of groundwater and surface-water resources in Nebraska, as well as concerns about the effect of groundwater irrigation on streamflow and water supplies needed to meet wildlife, recreational, and municipal needs. The lower Platte River provides nearly 100 percent of drinking-water supplies to Lincoln, Nebr., 40 to 60 percent of drinking-water supplies to Omaha, Nebr., and critical aquatic and riparian habitat for threatened 
and endangered species. The Lower Platte River Basinwide Management Plan has been developed jointly by the Nebraska Department of Natural Resources and seven NRDs to address some of these concerns for this part of the Platte River by managing groundwater and surface-water resources conjunctively.

To sustain flows in the lower Platte River that are needed for municipal water supplies, water managers have proposed projects aimed at temporary storage of surface water in upstream parts of the basin to mitigate periods of low flow in the lower Platte River. One area of interest to the Lower Platte North NRD and the Papio-Missouri River NRD is a reach of the lower Platte River that extends downstream from Fremont to its confluence with the Elkhorn River. Along this 23-mile reach, the Platte River is topographically higher in elevation than the Elkhorn River and a broad, flat alluvial valley separates the two streams. Within the study area, the Platte River has a gradient of approximately 4.4 feet per mile and the Elkhorn River flows for approximately 24 miles at a gradient 2.5 feet per mile. Because of the differences in stream gradient, the Platte River's bed at the Platte River at Leshara, Nebr., streamflow-gaging station (U.S. Geological Survey station 06796500 ) is roughly 40 feet higher in elevation than the Elkhorn River streambed at the Elkhorn River at Waterloo, Nebr., streamflow-gaging station (U.S. Geological Survey station 06800500). It can be inferred that water recharged from the Platte River to the alluvial aquifer will move downgradient to the Elkhorn River, increasing base flows therein, but the effects of varying flow in the Platte and Elkhorn Rivers, water levels in the alluvial aquifer, and local climatic conditions on the hydrologic system had not previously been evaluated.

To increase scientific understanding and provide support for any potential future streamflow augmentation projects, the Papio-Missouri River NRD, the Lower Platte North NRD, and the Nebraska Department of Natural Resources, in cooperation with the U.S. Geological Survey, initiated this study to examine groundwater/surface-water interaction along the lower Platte and Elkhorn Rivers upstream from their confluence. The study design described herein focused on understanding seasonal characteristics of groundwater movement and interaction with surface water during periods of high groundwater demand (June through August) and low groundwater demand (all other months). Understanding how groundwater movement and interaction with surface water are affected by streamflow conditions and local groundwater demand are critical to the development of any streamflow augmentation project intended to sustain streamflow and mitigate periods of low flow in the lower Platte River.

This report documents the methods of data collection and analysis, which include the collection of continuous groundwater and surface-water level elevation data along a transect from the Platte River to the Elkhorn River from May 2016 through September 2018. This report also provides water-level and streamflow data and interpretations from two synoptic water-level and streamflow surveys completed during high and low groundwater demand periods. During the high groundwater demand period in 2017, temperaturebased streambed flux estimates are also provided to improve the understanding of the temporal and spatial variability of groundwater/surface-water interaction along the lower Elkhorn River. Aerial thermal infrared (TIR) imagery was collected during a low groundwater demand period in December of 2017 to assess the spatial variability of the lower Elkhorn River.

The characteristics of groundwater movement and interaction of surface water described in this report apply to the hydrologic and local climatic conditions from 2016 to 2018 , which can be broadly characterized as having abnormally high precipitation. The annual precipitation rates measured at Valley, Nebr., for the years of 2015, 2016, and 2017, were 40, 44, and 36 inches, respectively, and was estimated to be 37 inches for 2018. These rates are well above the normal precipitation rate of 32.6 inches per year but were typical for the Elkhorn River Basin during the period of study. The measured daily discharge at the Elkhorn River at Waterloo, Nebr., streamflowgaging station remained above the long-term median for the entire period of study. No major reservoirs or flow diversions are along the main stem of the Elkhorn River and streamflow is generally reflective of the recent basin-wide climatic conditions. The streamflow of the Platte River at Leshara, Nebr., remained normal or slightly above normal for the duration of this study. An exception to this was during the spring of 2016, when streamflow was often more than double the median daily discharge from 1995-2016. The flow of the Platte River is affected by local climatic conditions and by releases from upstream reservoirs in Nebraska and Wyoming. Higher than normal reservoir releases in spring of 2016 were timed to accommodate runoff from spring snowmelt in the headwaters of the Platte River system.

Continuous streamflow and water-level data were interpreted to examine characteristics in groundwater movement and interaction with surface water between the Platte and Elkhorn Rivers during high and low groundwater demand periods. Although the streamflow for the Platte and Elkhorn Rivers and their tributaries was less during the high groundwater demand period the hydraulic gradient along a transect of recorder wells was identical ( 0.0012 foot per foot) during the high and low groundwater demand synoptic water-level and streamflow surveys. The hydraulic gradient between Platte and Elkhorn Rivers generally remained between 0.0011 and 0.0012 foot per foot. It can be inferred that the hydraulic gradient, which is the only temporally variable factor in Darcy's Law, is consistent throughout the study period, and that groundwater flow does not vary appreciably along this transect. There were exceptions during runoff events, which raised the stage in the Elkhorn River and decreased the estimated hydraulic gradient.

The northern part of the study area (north of the transect of recorder wells) had consistent groundwater and tributary flow from Big Slough, Rawhide Creek (Old Channel), and Rawhide Creek for low and high groundwater demand periods. In the southern part of the study area (south of the transect of recorder wells), tributary flow was much more variable 
and dependent on groundwater demand and flow conditions of the Platte River. Prior to the synoptic water-level and streamflow survey for the low groundwater demand period, the streamflow of the Platte River was slightly above normal, resulting in groundwater recharge from the Platte River and higher groundwater levels. During low groundwater demand period, groundwater flow was to the southeast and discharged to the Tributary to the Elkhorn River. Periods of lower than normal streamflow in the Platte River result in lower groundwater levels in areas near the Tributary to the Elkhorn River. Small decreases in the groundwater levels, such as those measured during the high groundwater demand period, can cause substantial changes in the streamflow of the Tributary to the Elkhorn River. The streamflow measured during the synoptic water-level and streamflow survey for the high groundwater demand period had decreased by nearly a factor of 20 when compared to the low groundwater demand period.

The volume of groundwater discharge received by the Elkhorn River was estimated by examining the changes in streamflow between measurement locations. Streamflow measurements indicate that the groundwater discharge received by the Elkhorn River in the southern part of the study area was seasonally variable, making it difficult, if not impossible, to estimate an annual value. Between the Elkhorn River at Waterloo, Nebr., streamflow-gaging station and the Q Street Bridge, streamflow measurements collected during the low groundwater demand period indicated a gain of 80 cubic feet per second, which is comparable to the gain estimated using aerial TIR imagery and water temperature data. Streamflow measurements collected during the high groundwater demand period indicate a loss of 80 cubic feet per second across this same reach. In assessing water supply conditions in the lower Platte River system, the term "loss" should be used with caution when referring to streamflow of the Elkhorn River. Most likely, flow from the Elkhorn River, which is "lost" to the groundwater system, will later discharge to surface water closer to the confluence of the Platte and Elkhorn Rivers as underflow. A calibrated groundwater flow model of the study area likely is required to predict the fate of this water and to quantify groundwater discharge during varying hydrologic conditions along this reach.

Aerial TIR imagery indicated that much of the groundwater discharge in the southern part of the study area is focused across a 3-mile reach where the Elkhorn River turns southwest, perpendicular to the regional groundwater flow direction. Points of focused groundwater discharge were not detected with aerial TIR imagery, indicating that groundwater discharge is diffuse rather than concentrated at focused points driven by strong regional groundwater flow gradients. Temperature-based streambed flux estimates demonstrated that the variability in the direction and magnitude of streambed flux rates indicates that strong regional groundwater gradients are not driving groundwater discharge, and hyporheic flow is the dominant groundwater/surface-water exchange process.

\section{References Cited}

Alpha Mach Inc., 2018, iButton technical specificationsiButton 22L, 22T, 22E: Ste-Julie, Quebec, Canada, Alpha Mach Inc., accessed July 14, 2018, at http://alphamach.com/ wp-content/uploads/2015/03/DS1922L-DS1922T-Rev-10. pdf.

Andersen, M.P., 2006, Heat as a ground water tracer: Ground Water, v. 43, no. 6, p. 951-968. [Also available at https:// doi.org/10.1111/j.1745-6584.2005.00052.x.]

Anding, D., and Kauth, R., 1970, Estimation of sea surface temperature from space: Remote Sensing of Environment, v. 1, no. 4, p. 217-220. [Also available at https://doi. org/10.1016/S0034-4257(70)80002-5.]

Atwell, B.H., MacDonald, R.B., and Bartolucci, L.A., 1971, Thermal mapping of streams from airborne radiometric scanning: Water Resources Bulletin, v. 7, no. 2, p. 228-243. [Also available at https://doi.org/10.1111/j.1752-1688.1971. tb05904.x.]

Banks, W.S.L., Paylor, R.L., and Hughes, W.B., 1996, Using thermal-infrared imagery to delineate ground-water discharge: Ground Water, v. 34, no. 3, p. 434-443. [Also available at https://doi.org/10.1111/j.1745-6584.1996. tb02024.x.]

Blasch, K.J., Constantz, J., and Stonestrom, D.A., 2007, Thermal methods for investigating ground-water recharge, in Stonestrom, D.A., Constantz, J., Ferre, T.P.A., and Leake, S.A., eds., Ground-water recharge in the arid and semiarid southwestern United States: U.S. Geological Survey Professional Paper 1703, p. 353-376. [Also available at https://pubs.usgs.gov/pp/pp1703/app1/.]

Briggs, M.A., Lautz, L.K., Buckley, S.F., and Lane, J.W., 2014, Practical limitations on the use of diurnal temperature signals to quantify groundwater upwelling: Journal of Hydrology, v. 519, p. 1739-1751. [Also available at https:// doi.org/10.1016/j.jhydrol.2014.09.030.]

Briggs, M.A., Voytek, E.B., Day-Lewis, F.D., Rosenberry, D.O., and Lane, J.W., 2013, Understanding water column and streambed thermal refugia for endangered mussels in the Delaware River: Environmental Science \& Technology, v. 47 , no. 20 , p. 11423-11431. [Also available at https://doi. org/10.1021/es4018893.]

Burchett, R.R., Reed, E.C., Dreeszen, V.H., and Prichard, G.E., 1975, Bedrock geologic map showing thickness of overlying Quaternary deposits, Fremont quadrangle and part of Omaha quadrangle: U.S. Geological Survey Miscellaneous Investigations Series Map I-905, scale 1:250,000. [Also available at https://ngmdb.usgs.gov/ Prodesc/proddesc_9797.htm.] 
Burns and McDonnell Engineering Company, Inc., 2017, 2016 Annual Nebraska Ordnance Plant Groundwater Report for the Platte West Water Production Facilities: Kansas City, Mo., Project no. 92445, 164 p.

Carney, C.P., Abraham, J.D., Cannia, J.C., and Steele, G.V., 2015, Final report on airborne electromagnetic geophysical surveys and hydrogeologic framework development for the Eastern Nebraska Water Resources Assessment—Volume 1 including Lewis and Clark, Lower Elkhorn, and PapioMissouri Natural Resources Districts: Vicksburg, Miss., Exploration Resources International, $152 \mathrm{p}$.

Center for Advanced Land Management Information Technologies, 2007, 2005 Nebraska land use patterns: Lincoln, Nebr., University of Nebraska-Lincoln, geospatial data, accessed June 19, 2019, at https://dnr.nebraska.gov/ sites/dnr.nebraska.gov/files/doc/data/land-use/landuse.zip.

Chen, X.H., 2005, Statistical and geostatistical features of streambed hydraulic conductivities in the Platte River, Nebraska: Environmental Geology, v. 48, no. 6, p. 693-701. [Also available at https://doi.org/10.1007/s00254-005-00071.]

Chen, X.H., Song, J., Cheng, C., Wang, D., and Lackey, S.O., 2009 , A new method for mapping variability in vertical seepage flux in streambeds: Hydrogeology Journal, v. 17, no. 3, p. 519-525. [Also available at https://doi.org/10.1007/ s10040-008-0384-0.]

Cheng, C., Song, J., Chen, X.H., and Wang, D., 2011, Statistical distribution of streambed vertical hydraulic conductivity along the Platte River, Nebraska: University of Nebraska-Lincoln, Papers in Natural Resources, 362. [Also available at http://digitalcommons.unl.edu/ natrespapers/362.]

Conservation and Survey Division, University of NebraskaLincoln, 2018a, Test-hole database: University of NebraskaLincoln, Conservation and Survey Division digital data, accessed June 7, 2018, at http://snr.unl.edu/data/ geologysoils/NebraskaTestHole/NebraskaTestHoleIntro. aspx.

Conservation and Survey Division, University of NebraskaLincoln, 2018b, Topographic regions, 2017: University of Nebraska-Lincoln, Institute of Agriculture and Natural Resources, digital data, accessed June 6, 2018, at http://snr. unl.edu/csd-esic/download/geographygis/stp/toporeg_stp. zip.
Constantz, J., Niswonger, R., and Stewart, A.E., 2008, Analysis of temperature gradients to determine stream exchanges with ground water, in Rosenberry, D.O., and LaBaugh, J.W., eds., Field techniques for estimating water fluxes between surface water and ground water: U.S. Geological Survey Techniques and Methods, book 4, chap. D2, p. 115-128. [Also available at https://pubs.usgs. gov/tm/04d02/pdf/TM4-D2-chap4.pdf.]

Constantz, J., Stewart, A.E., Niswonger, R., and Sarma, L., 2002, Analysis of temperature profiles for investigating stream losses beneath ephemeral channels: Water Resources Research, v. 38, no. 12, p. 1-13. [Also available at https:// doi.org/10.1029/2001WR001221.]

Cox, M.H., Su, G.W., and Constantz, J., 2007, Heat, chloride, and specific conductance as ground water tracers near streams: Ground Water, v. 45, no. 2, p. 187-195. [Also available at https://doi.org/10.1111/j.17456584.2006.00276.x.]

Culbertson, C.W., Huntington, T.G., Caldwell, J.M., and O'Donnell, C., 2014, Evaluation of aerial thermal infrared remote sensing to identify groundwater-discharge zones in the Meduxnekeag River, Houlton, Maine: U.S. Geological Survey Open-File Report 2013-1168, 21 p. [Also available at https://doi.org/10.3133/ofr20131168.]

Cunningham, W.L., and Schalk, C.W., comps., 2011, Groundwater technical procedures of the U.S. Geological Survey: U.S. Geological Survey Techniques and Methods, book 1, chap. A1, 151 p. [Also available at https://pubs. usgs.gov/tm/1a1/.]

Dietsch, B.J., Godberson, J.A., and Steele, G.V., 2009, Trends in streamflow characteristics of selected sites in the Elkhorn River, Salt Creek, and Lower Platte River basins, eastern Nebraska, 1928-2004, and evaluation of streamflows in relation to instream-flow criteria, 19532004: U.S. Geological Survey Scientific Investigations Report 2009-5011, 93 p. with appendixes. [Also available at https://pubs.usgs.gov/sir/2009/5011/.]

Dugdale, S.J., 2016, A practitioner's guide to thermal infrared remote sensing of rivers and streams - Recent advances, precautions, and considerations: WIREs Water, v. 3 , no. 2 , p. 251-268. [Also available at https://doi.org/10.1002/ wat2.1135.]

Dugdale, S.J., Bergeron, N.E., and St-Hilaire, A., 2015, Spatial distribution of thermal refuges analyzed in relation to riverscape hydromorphology using airborne thermal infrared imagery: Remote Sensing of Environment, v. 160, p. 43-55. [Also available at https://doi.org/10.1016/j. rse.2014.12.021.] 
Eddy-Miller, C.A., Constantz, J., Wheeler, J.D., Caldwell, R.R., and Barlow, J.R.B., 2012, Demonstrating usefulness of real-time monitoring at streambank wells coupled with active streamgages-Pilot studies in Wyoming, Montana, and Mississippi: U.S. Geological Survey Fact Sheet 2012-3054, 6 p. [Also available at https://doi.org/10.3133/ fs20123054.]

Eddy-Miller, C.A., Wheeler, J.D., and Essaid, H.I., 2009, Characterization of interactions between surface water and near-stream groundwater along Fish Creek, Teton County, Wyoming, by using heat as a tracer: U.S. Geological Survey Scientific Investigations Report 2009-5160, 53 p. [Also available at https://pubs.usgs.gov/sir/2009/5160/.]

Eppelbaum, L., Kutasov, I., and Pilchin, A., 2014, Applied Geothermics: New Delhi, India, Springer-Verlag Berlin Heidelberg, 751 p. [Also available at https://doi. org/10.1007/978-3-642-34023-9.]

Essaid, H.I., Zamora, C.M., McCarth, K.A., Vogel, J.R., and Wilson, J.T., 2007, Using heat to characterize streambed water flux variability in four stream reaches: Journal of Environmental Quality, v. 36, p. 1-14.

FLIR, 2011, FLIR SC8300HD User's manual, document number 27525-000, ver. 2: Portland, Oreg., FLIR Systems, Inc., $97 \mathrm{p}$.

FLIR, 2014a, FLIR ResearchIR v4.0 User's guide, document number 29354-000, revision 1: Portland, Oreg., FLIR Systems, Inc., 114 p.

FLIR, 2014b, FLIR Tools/Tools+user's manual: Wilsonville, Oreg., FLIR Systems, Inc., 162 p.

Freeze, R.A., and Cherry, J.A., 1979, Groundwater: Englewood, N.J., Prentice Hall, Inc., 604 p.

Gordon, R.P., Lautz, L.K., Briggs, M.A., and McKenzie, J.M., 2012, Automated calculation of vertical pore-water flux from field temperature time series using the VFLUX method and computer program: Journal of Hydrology (Amsterdam), v. 420-421, p. 142-158. [Also available at https://doi.org/10.1016/j.jhydrol.2011.11.053.]

Hatch, C.E., Fisher, A.T., Revenaugh, J.S., Constantz, J., and Ruehl, C., 2006, Quantifying surface water-groundwater interactions using time series analysis of streambed thermal records-Method development: Water Resources Research, v. 42 , no. 10, W10411, p. 1-12. [Also available at https:// doi.org/10.1029/2005WR004787.]

Helsel, D.R., and Hirsch, R.M., 2002, Statistical Methods in Water Resources: U.S. Geological Survey Techniques of Water-Resources Investigations, book 4, chap. A3, 522 p. [Also available at https://doi.org/10.3133/twri04A3.]
Hobza, C.M., and Andersen, M.J., 2010, Quantifying canal leakage rates using a mass-balance approach and heatbased hydraulic conductivity estimates in selected irrigation canals, western Nebraska, 2007 through 2009: U.S. Geological Survey Scientific Investigations Report 2010-5226, 45 p. [Also available at https://pubs.usgs.gov/ $\operatorname{sir} / 2010 / 5226 /$.

Hobza, C.M., and Schepers, A.R., 2018, Groundwater discharge characteristics for selected streams within the Loup River Basin, Nebraska: U.S. Geological Survey Scientific Investigations Report 2018-5093, 50 p. [Also available at https://doi.org/10.3133/sir20185093.]

Hobza, Christopher M., and Strauch, Kellan R., 2019, Waterlevel and aerial thermal infrared imagery data collected along the lower Platte and Elkhorn Rivers, Nebraska, 2016-2017: U.S. Geological Survey data release [Also available at https://doi.org/10.5066/P9EZLGSC.]

Irvine, D.J., Briggs, M.A., Cartwright, I., Scruggs, C.R., and Lautz, L.K., 2016, Improved vertical streambed flux estimation using multiple diurnal temperature methods in series: Ground Water, v. 55, no. 1, p. 73-80. [Also available at https://doi.org/10.1111/gwat.12436.]

Irvine, D.J., Lautz, L.K., Briggs, M.A., Gordon, R.P., and McKenzie, J.M., 2015, Experimental evaluation of the applicability of phase, amplitude, and combined methods to determine water flux and thermal diffusivity from temperature time series using VFLUX2: Journal of Hydrology, v. 531, p. 728-737. [Also available at http:// dx.doi.org/10.1016/j.jhydrol.2015.10.054.]

Keery, J., Binley, A., Crook, N., and Smith, J.W.N., 2007, Temporal and spatial variability of groundwater-surface water fluxes-Development and application of an analytical method using temperature time series: Journal of Hydrology (Amsterdam), v. 336, no. 1-2, p. 1-16. [Also available at https://doi.org/10.1016/j.jhydrol.2006.12.003.]

Kenney, T.A., 2010, Levels at gaging stations: U.S. Geological Survey Techniques and Methods, book 3, chap. A19, 60 p. [Also available at https://pubs.usgs.gov/tm/tm3A19/.]

Kenny, J.F., Barber, N.L., Hutson, S.S., Linsey, K.S., Lovelace, J.K., and Maupin, M.A., 2009, Estimated use of water in the United States in 2005: U.S. Geological Survey Circular 1344, 52 p. [Also available at https://pubs.usgs. gov/circ/1344/.]

Korus, J.T., Divine, D.P., Hanson, P.R., and Dillon, J.S., 2012, Three geologic cross-sections across portions of eastern Nebraska showing Quaternary lithologic units and stratigraphy of uppermost bedrock: University of NebraskaLincoln Conservation and Survey Division Correlations and Cross sections (CCS) 18, 16 p., [Also available at https:// www.enwra.org/media/CCS18_Korus-Divine-HansonDillon.pdf]. 
Korus, J.T., and Joeckel, R.M., 2011. Generalized geologic and hydrostratigraphic framework of Nebraska 2011, ver. 2. Conservation and Survey Division, School of Natural Resources, Institute of Agriculture and Natural Resources, University of Nebraska-Lincoln. Geologic Maps and Charts (GMC) 38 .

Lapham, W.W., 1989, Use of temperature profiles beneath streams to determine rates of vertical ground-water flow and vertical hydraulic conductivity: U.S. Geological Survey Water-Supply Paper 2337, 35 p. [Also available at https:// pubs.usgs.gov/wsp/2337/report.pdf.]

Lautz, L.K., 2010, Impacts of nonideal field conditions on vertical water velocity estimates from streambed temperature time series: Water Resources Research, v. 46, W01509, p. 1-14. [Also available at https://doi. org/10.1029/2009WR007917.]

Liu, C., Liu, J., Hu, Y., Wang, H., and Zheng, C., 2016, Airborne thermal remote sensing for estimation of groundwater discharge to a river: Ground Water, v. 54, no. 3, p. 363-373. [Also available at https://doi.org/10.1111/ gwat.12362.]

Loheide, S.P., and Gorelick, S.M., 2006, Quantifying streamaquifer interactions through analysis of remotely sensed thermographic profiles and in situ temperature histories: Environmental Science \& Technology, v. 40, no. 10, p. 3336-3341. [Also available at https://doi.org/10.1021/ es0522074.]

Lower Platte River Basin Coalition, 2018, Lower Platte River Basin Coalition Basin Water Management Plan: 50 p., accessed June 6, 2018, at https://lprbc.nebraska.gov/ MtgMaterials/LPRBC_Basin_Water_Management_Plan. pdf.

Luce, C.H., Tonina, D., Gariglio, F., and Applebee, R., 2013, Solutions for the diurnally forced advection-diffusion equation to estimate bulk fluid velocity and diffusivity in streambeds from temperature time series: Water Resources Research, v. 49, p. 488-506. [Also available at http://dx.doi. org/10.1029/2012WR012380.]

Magellan, 2007, MobileMapper CX getting started guide: San Dimas, Calif., Magellan, 86 p.

MathWorks, 2018, MATLAB R2015a: MATLAB Documentation, accessed October 10, 2018, at https://www. mathworks.com/help/mathlab.

Maupin, M.A., Kenny, J.F., Hutson, S.S., Lovelace, J.K., Barber, N.L., and Linsey, K.S., 2014, Estimated use of water in the United States in 2010: U.S. Geological Survey Circular 1405, 56 p. [Also available at https://dx.doi. org/10.3133/cir1405.]
McCallum, A.M., Andersen, M.S., Rau, G.C., and Acworth, R.I., 2012, A 1-D analytical method for estimating surface water-groundwater interactions and effective thermal diffusivity using temperature time series: Water Resources Research, v. 48, no. 11, W11532, p.1-11 [Also available at https://doi.org/10.1029/2012WR012007.]

McGuire, V.L., Ryter, D.W., and Flynn, A.S., 2012, Altitude, age, and quality of groundwater, Papio-Missouri River Natural Resources District, eastern Nebraska, 1992 to 2009: U.S. Geological Survey Scientific Investigations Report 2012-5036, 68 p. [Also available at https://doi.org/10.3133/ sir20125036.]

Mikhail, E.M., Bethel, J., and McGlone, C., 2001, Introduction to modern photogrammertry: Hoboken, N.J., John Wiley and Sons Publishers, $496 \mathrm{p}$.

Mueller, D.S., Wagner, C.R., Rehmel, M.S., Oberg, K.A., and Rainville, F., 2013, Measuring discharge with acoustic Doppler current profilers from a moving boat (ver. 2.0, December 2013): U.S. Geological Survey Techniques and Methods, book 3, chap. A22, 95 p. [Also available at https:// dx.doi.org/10.3133/tm3A22.]

Naranjo, R.C., and Turcotte, R., 2015, A new temperature profiling probe for investigating groundwater-surface water interaction: Water Resources Research, v. 51, no. 9, p. 7790-7797. [Also available at http://dx.doi. org/10.1002/2015WR017574.]

Naranjo, R.C., and Smith, D.W., 2016, Quantifying seepage using heat as a tracer in selected irrigation canals, Walker River Basin, Nevada, 2012 and 2013: U.S. Geological Survey Scientific Investigations Report 2016-5133, 169 p. [Also available at http://dx.doi.org/10.3133/sir20165133.]

National Center for Environmental Information, 2018, 1981-2010 U.S. Climate Normals: Asheville, N.C., National Center for Environmental Information, digital data, accessed June 5, 2018, at https://www.ncdc.noaa.gov/cdoweb/datatools/normals.

National Weather Service, 2019, Annual climatological report, Omaha, NE, 2018: Valley, Nebr., National Weather Service preliminary data, accessed February 15, 2019, at https:// w2.weather.gov/climate/getclimate.php?wfo=oax.

Nebraska Department of Natural Resources, 2011, NRCS LIDAR DEMs for Eastern Nebraska-2 meter: Lincoln, Nebr., digital data, accessed February 22, 2017, at ftp:// dnrftp.dnr.ne.gov/Pub/data/dems/LiDAR_East/. 
Nebraska Department of Natural Resources and U.S. Geological Survey, 1998, 7.5-minute digital elevation models - DEM-10 meter-Index for the State of Nebraska: Menlo Park, Calif., U.S. Geological Survey, digital data, accessed October 10, 2017, at https://dnr. nebraska.gov/sites/dnr.nebraska.gov/files/doc/data/ elevation/DEM.html.

Olsson Associates, 2009, Hydrogeologic evaluation and subarea delineation study: Lincoln, Nebr., Olsson Associates, 11 p., accessed June 7, 2018, at https://www. enwra.org/media/LPN_Subarea\%20Delineation\%20 Report\%20Final.pdf.

Onset, 2018, Tidbit v2 temp manual: Onset Computer Corporation, 2 p., accessed July 12, 2018, at https://www. onsetcomp.com/files/manual_pdfs/10385-J\%20UTBI001\%20Manual.pdf.

Papio-Missouri River Natural Resources District, 2017a, Papio-Missouri River Natural Resources District Groundwater Management Plan vol. 1: prepared by Olsson and Associates, 72 p., accessed June 5, 2018, at https:// www.papionrd.org/wp-content/uploads/2018/03/180209-PMRNRD-170724-Final_GMP_Vol-I-adopted_180208.pdf.

Papio-Missouri River Natural Resources District, 2017b, Papio-Missouri River Natural Resources District Groundwater Management Plan vol. 2: prepared by Olsson and Associates, 72 p., accessed June 5, 2018, at https:// www.papionrd.org/wp-content/uploads/2018/03/FinalGMP-Vol-II.pdf.

Rundquist, D., Murray, G., and Queen, L., 1985, Airborne thermal mapping of a flow-through lake in the Nebraska Sandhills: Water Resources Bulletin, v. 21, no. 6, p. 989-994. [Also available at https://doi. org/10.1111/j.1752-1688.1985.tb00193.x.]

Rydlund, P.H., Jr., and Densmore, B.K., 2012, Methods of practice and guidelines for using survey-grade global navigation satellite systems (GNSS) to establish vertical datum in the United States Geological Survey: U.S. Geological Survey Techniques and Methods, book 11, chap. D1, $102 \mathrm{p}$. with appendixes [Also available at https:// pubs.usgs.gov/tm/11d1/tm11-D1.pdf.]

Schulze-Makuch, D., 2005, Longitudinal dispersivity data and implications for scaling behavior: Ground Water, v. 43, no. 3, p. 443-456. [Also available at https://doi.org/10.1111/ j.1745-6584.2005.0051.x.].

Seiler Geospatial Division, 2018, Real-time GPS base staion networks - VRS and RTN's in the midwestern USA Part 1: Saint Louis, Mo., accessed June 12, 2018, at https:// www.seilergeo.com/2012/05/14/real-time-gps-base-stationnetworks-vrs-and-rtns-in-the-midwestern-usa-part-1/.
SimActive Inc, 2016, Correlator3D User manual, ver. 6.5: Montreal, Quebec, SimActive Inc., 88 p.

Sokkia Topcon Co., Ltd., 2000, SDL30 SDL50 digital level operator's manual: Kanagawa, Japan, 84 p., accessed June 11, 2018, at https://eu.sokkia.com/sites/default/files/ sc_files/downloads/sdl30-50_operators_manual_-_13th_ ed.pdf.

Song, J., Chen, X.H., Cheng, C., Wang, D., Lackey, S.L., and $\mathrm{Xu}, \mathrm{Z} ., 2009$, Feasibility of grain-size analysis methods for determination of vertical hydraulic conductivity of streambeds: Journal of Hydrology (Amsterdam), v. 375, no. 3-4, p. 428-437. [Also available at https://doi. org/10.1016/j.jhydrol.2009.06.043.]

Stallman, R.W., 1965, Steady 1-dimensional fluid flow in a semi-infinite porous medium with sinusoidal surface temperature: Journal of Geophysical Research, v. 70, no. 12, p. 2821-2827. [Also available at https://doi.org/10.1029/ JZ070i012p02821.]

Stonestrom, D.A., and Constantz, J., 2003, Heat as a tool for studying the movement of ground water near streams: U.S. Geological Survey Circular 1260, 96 p. [Also available at https://doi.org/10.3133/cir1260.]

TE Connectivity, 2018, KPSI 355: Hampton, Va.,

Measurement Specialties, Inc., accessed June 11, 2018, at http://www.te.com/commerce/DocumentDelivery/DDECont roller?Action=srchrtrv\&DocNm=KPSI_500\&DocType $=\mathrm{Da}$ ta + Sheet\&DocLang=English\&DocFormat $=$ pdf\&PartCntxt $=$ CAT-WLS0017.

Topcon Positioning Systems, Inc., 2018, Topcon HiPer SR: Livermore, Calif., Topcon Positioning Systems, Inc, accessed August 6, 2018, at https://www.topconpositioning. com/sites/default/files/product_files/hiper_sr_ broch_7010_2108_revd_sm_3.pdf.

Torgersen, C.E., Faux, R.N., McIntosh, B.A., Poage, N.J., and Norton, D.J., 2001, Airborne thermal remote sensing for water temperature assessment in rivers and streams: Remote Sensing of Environment, v. 76, no. 3, p. 386-398. [Also available at https://doi.org/10.1016/S0034-4257(01)001869.]

Torgersen, C.E., Price, D.M., Li, H.W., and McIntosh, B.A., 1999, Multiscale thermal refugia and stream habitat associations of chinook salmon in northeastern Oregon: Ecological Applications, v. 9, no. 1, p. 301319. [Also available at https://doi.org/10.1890/10510761(1999)009[0301:MTRASH]2.0.CO;2.]

Trimble Navigation Limited, 2009, Trimble R8 GNSS Receiver user guide (revision a): Sunnyvale, Calif., Trimble Navigation Limited, 78 p., accessed June 11, 2018, at http:// trl.trimble.com/docushare/dsweb/Get/Document-666214/ R8-R6-R4-5800M3_v411A_UserGuide.pdf. 
Turnipseed, D.P., and Sauer, V.B., 2010, Discharge measurements at gaging stations: U.S. Geological Survey Techniques and Methods, book 3, chap. A8, 87 p. [Also available at https://pubs.usgs.gov/tm/tm3-a8/.]

U.S. Geological Survey, 2004, Policy on the use of the FlowTracker for discharge measurements: U.S. Geological Survey Office of Surface Water Technical Memorandum 2004.04, accessed June 11, 2018, at https://hydroacoustics. usgs.gov/memos/OSW2004-04.pdf.

U.S. Geological Survey, 2018a, USGS water data for the Nation: U.S. Geological Survey National Water Information System database, accessed September 30, 2018, https://doi. org/10.5066/F7P55KJN.

U.S. Geological Survey, 2018b, Real-Time Network (RTN) surveying: accessed June 11, 2018, at https://water.usgs. gov/osw/gps/real-time_network.html.

Verstraeten, I.M., and Ellis, M.J., 1995, Reconnaissance of ground-water quality in the Papio-Missouri River Natural Resources District, eastern Nebraska, July through September 1992: U.S. Geological Survey Water-Resources Investigations Report 94-4197, 90 p. [Also available at https://pubs.er.usgs.gov/publication/wri944197.]
Vatland, S.J., Gresswell, R.E., and Poole, G.C., 2015, Quantifying stream thermal regimes at multiple scalesCombining thermal infrared imagery and stationary stream temperature data in a novel modeling framework: Water Resources Research, v. 51, no. 1, p. 31-46. [Also available at https://doi.org/10.1002/2014WR015588.]

Wagner, R.J., Boulger, R.W., Jr., Oblinger, C.J., and Smith, B.A., 2006, Guidelines and standard procedures for continuous water-quality monitors - Station operation, record computation, and data reporting: U.S. Geological Survey Techniques and Methods, book 1, chap. D3, 51 p., 8 attachments. [Also available at https://pubs.water.usgs. gov/tm1d3.]

Zamora, C., 2008, Estimating water fluxes across the sediment-water interface in the Lower Merced River, California: U.S. Geological Survey Scientific Investigations Report 2007-5216, 47 p. [Also available at https://pubs. usgs.gov/sir/2007/5216/.]
For more information about this publication, contact:

Director, USGS Nebraska Water Science Center

5231 South 19th Street

Lincoln, NE 68512

402-328-4100

For additional information, visit: https://www.usgs.gov/centers/ ne-water

Publishing support provided by the

Rolla and Madison Publishing Service Centers 

-

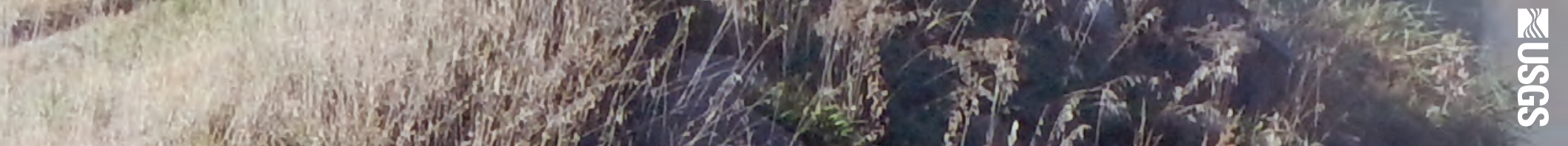

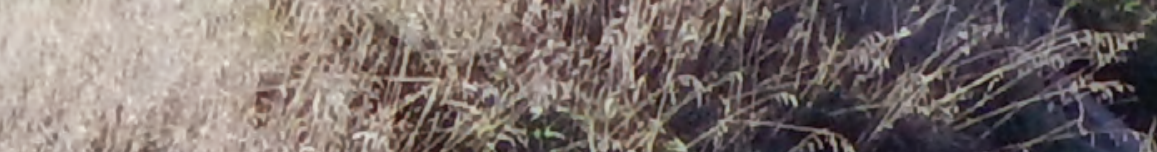

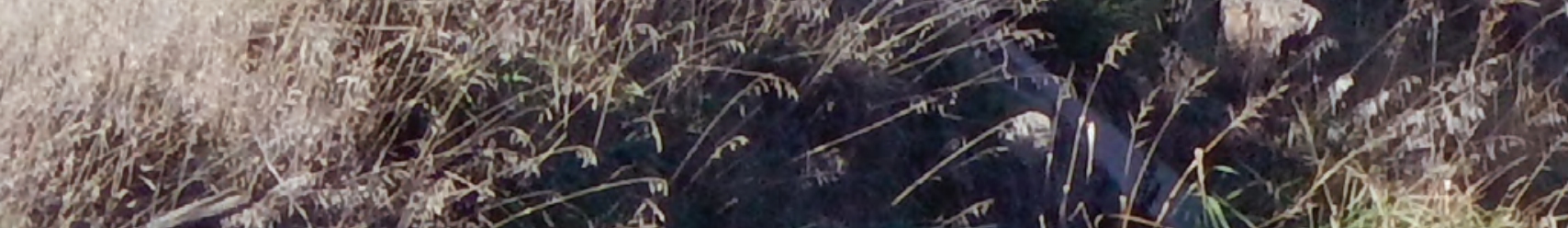
Q 1 ( 9470 in

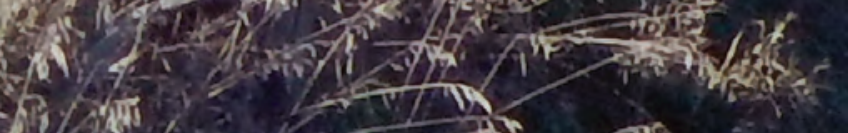

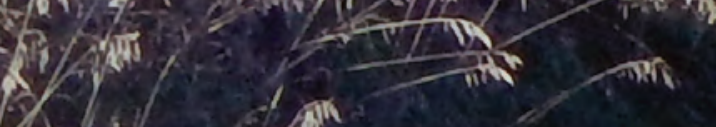

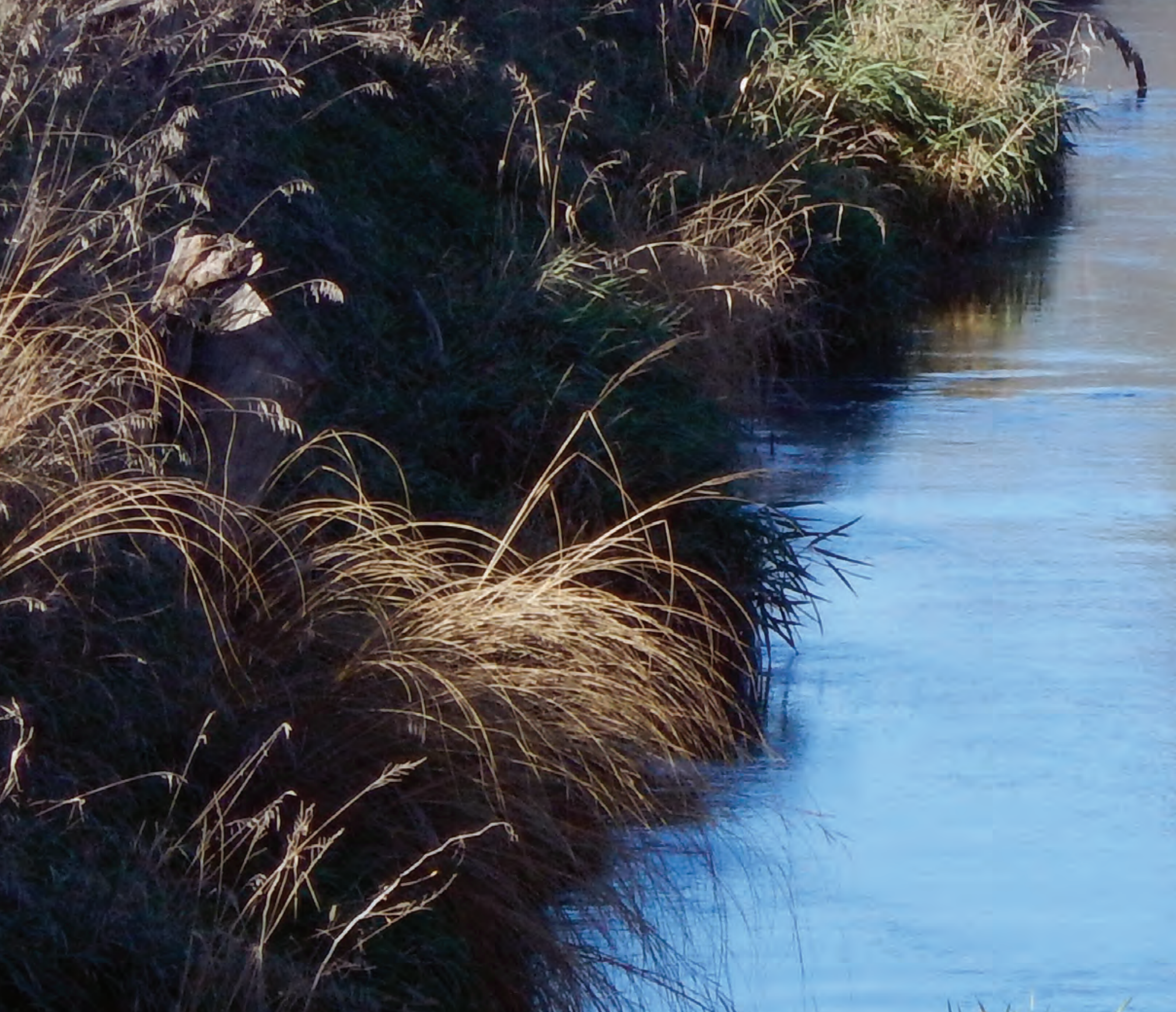

-e $19+\%$ -

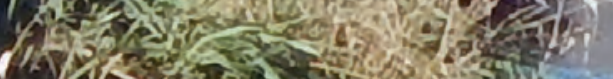

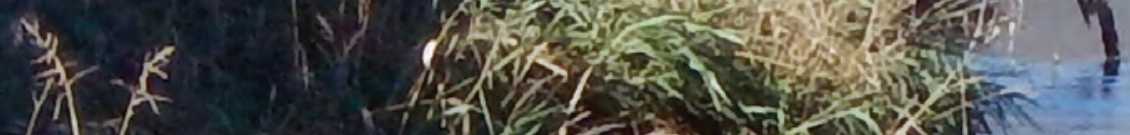
1.

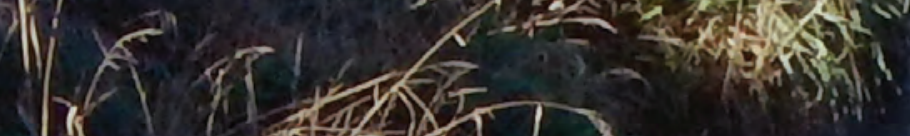

